\title{
IUCN
}

\section{Seal Range State Policy and Management Review}

D.H.M. Cumming

A report prepared on behalf of the IUCN Sustainable Use and Livelihoods Specialist Group

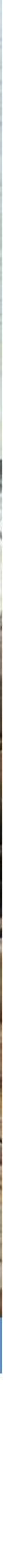




\section{About IUCN}

IUCN, International Union for Conservation of Nature, helps the world find pragmatic solutions to our most pressing environment and development challenges. IUCN's work focuses on valuing and conserving nature, ensuring effective and equitable governance of its use, and deploying nature-based solutions to global challenges in climate food and development. IUCN supports scientific research, manages field projects all over the world, and brings governments, NGOs, the UN and companies together to develop policy, laws and best practice. IUCN is the world's oldest and largest global environmental organization, with almost 1,300 government and NGO Members and more than 15,000 volunteer experts in 185 countries. IUCN's work is supported by almost 1,000 staff in 45 offices and hundreds of partners in public, NGO and private sectors around the world. http://www.iucn.org

\section{IUCN Species Survival Commission}

The Species Survival Commission (SSC) is the largest of IUCN's six volunteer commissions with a diverse global membership of nearly 10,000 experts. With biodiversity loss as one of the world's most pressing crises, and many species declining to critical levels, the SSC drives its efforts and expertise to conserving nature through positive and informed action. This is achieved through the strength of its dedicated sciencebased network of volunteer experts, who constitute the invaluable "power house" of the SSC. Web: http:// www.iucn.org/ssc

\section{IUCN Commission on Environment, Economics and Social Policy}

CEESP, the IUCN Commission on Environmental, Economic and Social Policy, is an interdisciplinary network of professionals whose mission is to act as a source of advice of the environmental, economic, social and cultural factors that affect natural resources and biological diversity, and to provide guidance and support towards effective policies and practices in environmental conservation and sustainable development. http://www.iucn.org/ceesp

\section{IUCN SSC/CEESP Sustainable Use and Livelihoods Specialist Group}

The SSC/CEESP Sustainable Use and Livelihoods Specialist Group is a global, volunteer, expert network formed by IUCN as a joint initiative of the Species Survival Commission (SSC) and the Commission on Environmental, Economic and Social Policy (CEESP). Bridging the social and biological strengths of SSC and CEESP, it is uniquely placed to provide credible, sound technical advice on sustainable use and livelihoods. SULi's misison is to promote both conservation and livelihoods through enhancing equitable and sustainable use of wild species and their associated ecosystems. http://iucn.org/suli 
Seal Range State Policy and Management Review 



\section{Seal Range State Policy and Management Review}

\section{D.H.M. Cumming}

A report prepared on behalf of the IUCN Sustainable Use and Livelihoods Specialist Group

Author Information:

David H. M. Cumming

Honorary Professor, Percy Fitzpatrick Institute,

University of Cape Town /

Research Associate, Tropical Resource Ecology,

University of Zimbabwe

19 Walmer Drive, Highlands

Harare, Zimbabwe 
The designation of geographical entities in this book, and the presentation of the material, do not imply the expression of any opinion whatsoever on the part of IUCN, the European Union, the ACP Secretariat or the compilers concerning the legal status of any country, territory, or area, or of its authorities, or concerning the delimitation of its frontiers or boundaries. This publication has been produced with the support of the International Fur Federation. The views expressed in this publication do not necessarily reflect those of IUCN, the European Union, the ACP Secretariat, the International Fur Federation, or other participating organizations.

Published by: IUCN, Gland, Switzerland

Copyright: @ 2015 International Union for Conservation of Nature and Natural Resources

Reproduction of this publication for educational or other non-commercial purposes is authorized without prior written permission from the copyright holder provided the source is fully acknowledged. Reproduction of this publication for resale or other commercial purposes is prohibited without prior written permission of the copyright holder.

Citation: Cumming, D. H. M. (2015). Seal Range State Policy and Management Review. Gland, Switzerland: IUCN SSC/CEESP Sustainable Use and Livelihoods Specialist Group. xiv + 94pp.

ISBN: 978-2-8317-1764-7

DOI: http://dx.doi.org/10.2305/IUCN.CH.2015.SSC-OP.55.en

Front Cover: Colony of cape fur seals from Cape Point, Namibia. (c) Davide Guidolin Back Cover: Grey seal (Halichoerus grypus) in the Canadian Arctic. (O) Raldi Somers

Layout and printing by: Conservation Visions Inc.

Available from: IUCN (International Union for Conservation of Nature)

Global Species Programme

Rue Mauverney 28

1196 Gland

Switzerland

Tel +41229990000

Fax +41229990002

www.iucn.org/publications

Also available at https://portals.iucn.org/library 


\section{SUMMARY}

Seals have been harvested and their products (furs, oils and meat) used by humans for thousands of years. However, large-scale commercial sealing is a comparatively recent development. It began in the $17^{\text {th }}$ century and reached a peak in the $19^{\text {th }}$ and early $20^{\text {th }}$ centuries. In the northern hemisphere, northern fur seals and harp seals were the main targets of these harvests. The primary products were pelts and oil. Annual catches exceeded 300,000 northern fur seals in the late 1860s, and more than 700,000 harp seals in the 1920s and 1950s. In the southern oceans, sealing for various fur seal species collapsed by the 1920s as a result of over-exploitation. Presently, sustainable commercial harvesting of seals (mainly harp seals) by Canada takes place by in the western North Atlantic and by Norway in the Greenland Sea. Cape fur seals are harvested commercially on the coast of Namibia. Indigenous peoples living in the North Atlantic, North Pacific and in arctic coastal areas harvest several species of seals. This harvest represents an integral component of both their household economies and culture. The primary objective of this study is to survey range state policies and management responses to growing or abundant seal populations.

The management of seals ${ }^{1}$ and related policies in Antarctica, the European Union (EU) and six range states, all of which include abundant or growing populations of seals, are reviewed. The range states are Canada, Greenland, Norway, Russia and the United States of America (USA), which have territories bordering on the Arctic, and Namibia in the southern hemisphere. Eight seal species are included in this review, six of which inhabit northern areas including harp (Pagophilus groenlandicus), hooded (Cystophora cristata), northern fur (Callorbinus ursinus), grey (Halichoerus grypus), harbour (Phoca vitulina) and ringed (Pusa hispida) seals, while two species inhabit southern areas, namely, Cape fur (Arctocephalus pusillus) and crabeater (Lobodon carcinophagus) seals. Harp, crabeater and ringed seals are the most abundant of the eight species included in this review, and account for about $75 \%$ of the global combined population of approximately 23 million seals within these eight species worldwide.

Harp seals are distributed in three populations. The largest is the Northwest Atlantic population of 7.5 million that moves between the Gulf of St Lawrence and Baffin Bay from which an average of $\sim 150,000$ seals/year have been harvested over the last five years. The second population in the Greenland Sea is estimated to number 627,000 with an annual take of 5,000 to 8,000 a year in the West Ice (off Jan Mayen) by Norway. The third population breeds in the White Sea (or East Ice); it is estimated to number some 1.36 million seals. However, no commercial harvests have taken place in the Barents and White seas by Russia since 2009, or by Norway since 2012 where an annual take of 7,000 was allocated. Animals from the West and East Ice breeding areas mix during the summer in the Northern Barents Sea, but return to their respective breeding areas. The species is listed as 'Least Concern' by IUCN.

Hooded seals are also found in three populations, one in "The Front" (off Newfoundland), another in Davis Strait and a third in the West Ice (near Jan Mayen in the Northeast Atlantic). The Canadian population was last censused in 2005 with an estimate of 593,500 and an annual take of less than 5,000 from a total allowable catch (TAC) of 8,200 . The average number of hooded seals taken annually in Greenland was 5,867 between 1993 and 2009. The Northeast Atlantic hooded seal population has declined by $85-90 \%$ over the last few decades, and a zero quota for the commercial harvest has been in place since 2008. The species is classified as 'Vulnerable' by IUCN, and is classified as 'Not at Risk' in Canada.

Northern fur seals occur across the North Pacific Ocean. Their numbers have been declining for several years along with several other pinniped species in the North Pacific, probably due to a climate induced regime shift. The most recent estimate (2013) for the fur seal stock in the Eastern Pacific is 639,545. The

\footnotetext{
${ }^{1}$ In the context of this report "seals" refers to true seals and fur seals and excludes sea lions and walruses
} 
species is classified as 'depleted' under the USA Marine Mammal Protection Act and as 'Vulnerable' by IUCN.

Grey seals are distributed in the North Atlantic in three main sub-populations, namely, in the West Atlantic (Gulf of Maine, Gulf of St Lawrence and northward to southern Labrador), in the East Atlantic centred on the United Kingdom (UK), and in the Baltic Sea. All populations are considered to be growing with an overall abundance estimate of $\sim 550,000$ seals. Grey seals are increasingly being implicated in seal-fisheries conflicts and commercial harvests are taken in Canada with an annual take of up to 5,000. In Norway the annual average take was 302 between 2008 and 2012. The IUCN status for the species is 'Least Concern'. Grey seals are protected in Greenland waters, where they are extremely rare.

Harbour seals are widely distributed in coastal waters of the northern hemisphere and, although some subspecies are in small and declining populations, overall the species is considered to be stable or increasing. The total population of harbour seals within the range states considered in this report is approximately 360,000 , however, some of the population estimates date back several years. Recovering populations of harbour seals are being implicated in coastal fisheries conflicts in Europe and the USA. The species is listed as 'Least Concern' by the IUCN. Harbour seals are protected in Greenland waters where, as with grey seals, they are extremely rare.

Ringed seals are distributed throughout the Arctic Ocean and adjacent seas and their global population status is uncertain, given the impacts of climate change on the ice on which they depend. There is no commercial harvesting of ringed seals but it is an important component of subsistence harvests. The Greenland annual harvest averaged 79,206 seals between 1993 and 2009. Figures for subsistence harvests in northern Canada are incomplete. Annual harvests in the Okhotsk Sea were as high as 98,000 in 1960 but declined to 196 seals in 2000. The annual Alaskan subsistence harvest is estimated to be approximately 9,500. The species is now listed as a 'strategic stock' under the US MMPA and as 'endangered' under the US Endangered Species Act. In Canada it is listed as 'not at risk', and globally it is classified as being 'Least Concern' by the IUCN.

Cape fur seals occur along the southern African coast from southern Angola in the west to Algoa Bay in the southeast. The species is harvested commercially in Namibia with a TAC of 92,000 with an average annual take of 45,600 (for 2007-2011) from a population of 1.2 million seals. The South African population of 700,000 seals is not harvested. The species is listed as 'Least Concern' by the IUCN.

Crabeater seal distribution is limited to the Antarctic and the population is estimated to number some 9.5 million. The species is not harvested commercially, or for subsistence, and is listed as being 'Least Concern' by the IUCN.

Although available figures reporting the number of seals harvested from the seven species subjected to harvests are incomplete, it is likely that the total harvest $(\sim 300,000)$ currently amounts to less than $2.2 \%$ of the overall number of about 13.9 million seals. However, the mortality figures for subsistence harvests, non-commercial take (e.g., protecting fish farms and fishing gear, and fisheries bycatch) are largely unknown. If the levels of pinniped bycatch of about 350,000 per annum that was reported for the 1990s have persisted, then overall annual human caused mortality could be more than 650,000 seals (or $4.6 \%$ ) of the combined populations. Current bans on trade, and resulting depressed markets for seal products, reduce or eliminate incentives to recover products from this potentially valuable resource.

The conservation and management of seals are issues addressed by both national and international legislation and policies. The Convention on Biological Diversity (CBD) and the Convention on International Trade in Endangered Species of Wild Fauna and Flora (CITES), both major international treaties, work together with regional agreements such as the Bern Convention, Helsinki Convention to administer the management and sustainable use of seals. The Antarctic Treaty System includes a 
convention focusing specifically on seals, the Convention for the Conservation of Antarctic Seals (1972). Each of the noted international conventions and treaties include clauses that make provision for the sustainable use of living natural resources, together with safeguards to prevent overexploitation. Regional bodies for managing fisheries and marine mammals, such as the International Council for the Exploration of the Sea (ICES) and the North Atlantic Marine Mammal Commission (NAMMCO), provide additional levels of oversight concerning the management and harvesting of seals.

At national levels, legislation and policies governing marine mammals and seals fall primarily under the umbrella of marine resources, or fisheries, legislation and similarly includes provisions for the conservation and sustainable use of seals, and also stipulations for controlling numbers where these might impact on fisheries. In the case of the EU there are several overlapping jurisdictions governing the conservation and management of seals. These include the Bern, Helsinki and OSPAR Conventions, EU legislation (such as the Habitats Directive), and the various national laws of specific countries within the EU that have marine resources. Aspects of the Marine (Scotland) Act of 2010 and the Finland Seal Management Plan of 2007 are outlined as examples of national legislation and management systems within the EU countries. Only three seal species are present in the EU waters, namely, harbour, grey and ringed seals. Their numbers, as compared with those in the Northwest Atlantic as a whole, are low. Accordingly, in broad terms, the emphasis within the EU is on supporting the recovery of seal populations, finding ways to reduce associated increases in seal-fishery conflicts, and establishing protected areas. Legislation and policy instruments at regional and national levels retain the option to control seal numbers should the need arise.

Three countries, Canada, Norway, and Namibia, currently conduct annual commercial seal harvests. Harp, hooded and grey seals are harvested in Canadian waters within the framework of a detailed fiveyear (2011- 2015) management plan. Norway harvests harp seals in the Greenland Sea (West Ice), harp seals in the Barents Sea (a mix of West Ice and East Ice animals), and grey and harbour seals off the Norwegian coast. Norway and Russia used to jointly manage sealing (and fisheries) in the West Ice, but Russia, has not harvested seals in this area in recent years. These two countries also jointly manage the White Sea/Barents Sea population. ICES and its Working Group on Harp and Hooded Seals oversee the management of harp and hooded seal populations in the above seas. Annual total allowable catches (TACs) are established for commercial harvests, based on the most recent population estimates and precautionary models to guide sustainable harvests.

Namibia harvests Cape fur seals each year from three rookeries on the Namibian coast within the framework of TACs set for pups and adult males. A management plan for seals does appear to have been published. In Greenland, licensed full time and part time hunters harvest harp, hooded, ringed, and bearded seals throughout the year. National quotas or TACs are not set for seal harvests in Greenland waters, although there is a suggestion in a Government of Greenland report that hunting seasons, hunting areas, and quotas for licensed full time and part time hunters may be set at local levels. An explicit national management plan does not appear to have been developed for seals. In the USA, seals are managed in accordance with the provisions of the Marine Mammal Protection Act and annual marine mammal stock reports. For species identified as being at risk, specific management plans are developed, and it is in terms of such a plan that the annual subsistence TAC is set for northern fur seals in the Pribilof Islands. In Alaska aboriginal hunters do not require a licence to hunt seals. Within the EU, Finland and Sweden have developed management plans for seals in their waters in the Baltic Sea, and a management plan for seals in the Wadden Sea is being implemented jointly by the Netherlands, Germany and Denmark.

2/ But has not done so for 2013 and 2014. 
Russian commercial harvests of harp seals in the Barents and White Seas ceased in 2009 (see above) and no recent information on subsistence harvesting of seals in the Russian Federation was found.

The economics of commercial sealing has apparently not been investigated in any depth. A 2001 financial analysis of the seal hunt in Canada and a 2011 study of the seal harvest and seal watching in Namibia both concluded that seal harvesting contributed little to national economies, employed few people and could be dispensed with. Comprehensive and competent economic analysis, as opposed to financial accounting, of seal harvesting and trade in seal products for both commercial and subsistence harvests, is lacking.

The import of seal products into the USA was banned in 1972 and the EU imposed a moratorium on the importation of seal furs in 1982-83 that was later extended to 1989. In 2006 the EU again gave notice of its intention to ban imports of seal products on moral grounds and the ban came into force in 2009. The matter was taken to the World Trade Organisation (WTO) and after a lengthy period of arbitration the WTO ruled in favour of the EU in May 2014. These measures have created direct and substantial extraterritorial impacts both on the returns from harvesting seals, and on livelihoods of those living in circumpolar regions. The introduction of the EU ban on the import of seal products caused the value of seal pelts to decline by more than $50 \%$ for Greenland (despite the exception for skins produced from subsistence hunting), and the value of pelts in Canada to decline from nearly C\$35 million in 2006 to C\$ 2 million in 2010. In a response to bans on the trade in seal products, sealing is subsidised in Canada and Greenland. Sealing was also subsidised in Norway until December 2014.

Although the EU ban included an exemption for seal products taken by subsistence hunters, i.e. products from Greenland and the Canadian north, the ban resulted in a substantial decline in the value and marketability of seal furs, with direct effects on household economies in these regions. Confusion and alternative interpretations surrounding the use of term "subsistence" in the context of harvesting and marketing natural resources by aboriginal peoples has exacerbated the problem. Subsistence harvesting in this context necessarily involves more than harvesting for personal use. Seals provide a household with both "country food" and a potentially valuable and marketable product in the form of sealskins, which in turn provides the cash needed to maintain the equipment required for successful harvesting of a range of country foods. Analysis of the impacts of the recent ban on households is lacking, as are studies of the micro- and macro-economics (as opposed to financial assessments) of the role of marine mammals in the livelihoods of aboriginal people in the Arctic and sub-Arctic regions. Also missing is information on the question of whether rural communities, for which seals are an important component of their livelihoods, actively manage the resource.

Conflicts between seals and fisheries can involve both direct effects, such as seals damaging fishing gear and trapped fish, and indirect effects, such as predation on fish stocks. Fisheries impact seal populations through bycatch mortality, bounty hunting, depleted fish stocks and changes in marine food webs. Increasing numbers of seals in many of the populations examined in this report have resulted in an increase in perceptions of seal-fishery conflicts. This has been reflected in the case of grey seals and coastal fisheries and fish farming in both Europe and North America. It has also been suggested that harp and hooded seals might be inhibiting the recovery of cod stocks in the Northwest Atlantic.

The current levels of bycatch, human caused mortality, and culling of seals in seal-fishery interactions, are not well documented and there appears to be a major gap in information on the recovery and use of seal products resulting from these sources of mortality. Research over the last two decades on the complexity of marine food webs and role of top predators, such as seals, in structuring marine ecosystems indicates that reducing seal populations is as likely to lead to unexpected adverse impacts on fish stocks as it is to improve them. For example, reducing seal populations can result in the release of alternative intermediate fish predators that have an even greater impact on a selected stock and could inhibit its recovery. Increasing moves towards implementing ecosystem-based management of marine resources are 
also resulting in a more cautious approach to the management of increasing marine mammal populations and an appreciation of their key role in structuring ecosystems.

Across the spectrum of human-seal interactions, a multitude of ecological, economic, social and governance issues arise. At the root of many of the more controversial issues relating to the conservation and management of seals are deeply rooted beliefs and largely irresolvable ethical divisions between different countries and components of society. Though analysis of these issues is important, it is beyond the scope of this report. 


\section{Table of Contents}

Acronyms

Acknowledgements, Disclaimer and Citation

List of Tables

List of Figures

1. INTRODUCTION

1.1 International Conventions

1.1.1 CBD and the Addis Ababa Principles

1.1.2 CITES

1.2 Regional conventions, treaties and commissions

2. CANADA

2.1 Seal population numbers and harvests

2.2 Government policy and management of seals

2.3 Issues relating to policy and practice

2.3.1 Animal welfare

2.3.2 Precautionary approach

2.4 Seals and fisheries conflicts

2.5 Economics of seal harvesting and livelihood issues in Canada

3. GREENLAND

3.1 Seal population numbers and harvests

3.2 Government policy and management of seals

3.3. Seals and fisheries conflicts

3.4 Economics of seal harvesting and livelihood issues

4. NORWAY

4.1 Seal population numbers and harvests

4.2 Government policy and management of seals

4.3. Seals and fisheries conflicts

4.4 Economics of seal harvesting and livelihood issues

5. RUSSIA

5.1 Seal population numbers and harvests

5.2 Government policy and management of seals

5.3. Seals and fisheries conflicts

5.4 Economics of seal harvesting and livelihood issues

6. EUROPEAN UINION COUNTRIES

6.1 Seal population numbers and harvests

6.2 European policy and management of seals

6.2.1 European Habitats Directive

6.2.2 The Berne Convention

6.2.3 The Helsinki Convention and the Baltic Sea

6.2.4 The Bonn Convention

6.2.5 The OSPAR Convention

6.2.6 The British Isles

6.2.6.1 United Kingdom

6.2.6.2 Scotland

6.2.7 Finland 
6.3 Seals and fisheries conflicts

6.4 Economics of seal harvesting and livelihood issues

7. UNITED STATES OF AMERICA

7.1 Seal population numbers and harvests

7.2 Government policy and management of seals

7.2.1 Legislation governing marine resources and seals

7.2.2 Management plans

7.3. Seals and fisheries conflicts

7.4 Economics of seal harvesting and livelihood issues

8. NAMIBIA

8.1 Seal population numbers and harvests

8.2 Government policy and management of seals

8.3. Seals and fisheries conflicts

8.4 Economics of seal harvesting and livelihood issues

9. ANTARCTICA

9.1 Seal population numbers

9.2 Policy and management of seals

9.2.1 Convention for the conservation of Antarctic seals

9.2.2 Convention on the Conservation of Antarctic Marine Living Resources (1980)

9.2.3 Protocol on Environmental Protection to the Antarctic Treaty (1992)

9.3. Seals and fisheries conflicts

9.4 Economics of seal harvesting and livelihood issues

10. DISCUSSION and CONCLUSIONS

10.1 Introduction

10.2 Legal and policy frameworks

10.2.1 International conventions

10.2.2 National laws and policies

10.3 Seal population status, trends and harvests

10.4 Extra-territorial impacts of policies

10.5 Seal-fishery conflicts and ecosystem management

11. REFERENCES

11.1 Literature cited

11.2. Additional literature consulted

12. ANNEXES

12.1 Terms of Reference

12.2 CBD Ecosystem Approach Principles

12.3 Supplementary legal texts 


\section{Acronyms}

\begin{tabular}{|c|c|}
\hline APIS & Antarctic Pack Ice Seals programme \\
\hline ATS & Antarctic Treaty System \\
\hline CBD & Convention on Biodiversity \\
\hline CITES & International Convention on Trade in Endangered Species \\
\hline COSEWIC & Committee on the Status of Endangered Wildlife in Canada \\
\hline DDK & Danish Kroner \\
\hline $\mathrm{DFO}$ & Department of Fisheries and Oceans Canada \\
\hline $\mathrm{EC}$ & European Commission \\
\hline EFSA & European Food Safety Agency \\
\hline EU & European Union \\
\hline HELCOM & Helsinki Convention Commission \\
\hline ICES & The International Council for the Exploration of the Sea \\
\hline IUCN & International Union for the Conservation of Nature \\
\hline MMPA & Marine Mammal Protection Act (USA) \\
\hline MSE & Management Strategic Evaluation \\
\hline NAMMCO & North Atlantic Marine Mammal Commission \\
\hline NMFS & National Marine Fisheries Service \\
\hline NOAA & National Oceanic and Atmospheric Agency \\
\hline OSP & Optimum Sustainable Population \\
\hline SCAR & Scientific Committee on Antarctic Research of the International Council of Scientific Unions \\
\hline SCOS & Special Committee on Seals (UK) \\
\hline SSC & Species Survival Commission (of IUCN) \\
\hline TAC & Total Allowable Catch \\
\hline UK & United Kingdom \\
\hline USA & United States of America \\
\hline USD & United States Dollar \\
\hline
\end{tabular}

\section{Acknowledgements}

This study, commissioned by the International Fur Federation, was conducted under the auspices of the IUCN Species Survival Commission and its Sustainable Use and Livelihoods Specialist Group (SULi). Shane Mahoney, Jackie Snow and members of the IUCN/SSC Pinniped Specialist Group, managed the study and reviewed the initial draft and final reports. I am particularly grateful to Rosie Cooney, Kit M. Kovacs, Lloyd Lowry, Shane Mahoney and Rick Baydack for their detailed and very constructive reviews of the initial and penultimate drafts. I also thank Meg Cumming for commenting on successive drafts of this report.

\section{Disclaimer}

This publication represents the collective effort of many members of the IUCN CEESP/SSC Sustainable Use and Livelihood Specialist Group (SULi), as well as the IUCN SSC Pinniped Specialist Group (PSG), and is a product of SULi. However, the views expressed in this publication do not necessarily reflect those of IUCN, CEESP, SSC, PSG or SULi.

This report was overseen by a technical panel composed of two members of SULi and two members of the PSG. Feedback was also received from Inuit Tapiriit Kanatami (ITK). The study was funded by IFF, who played no part in determining the content. 


\section{Suggested citation:}

Cumming, D.H.M. (2015) Seal range state policy and management review. A report prepared for the Sustainable Use and Livelihoods Specialist Group of IUCN and the International Fur Federation.

\section{List of Tables}

Table 2.1 Total Allowable Catch (TAC), catch, and percentage of TAC taken for the Canadian harvest of harp seals and the Greenland harvest of harp seals (x 1,000). (Source: DFO 2012, M. Hammill and A. Rosing-Asvid in litt. September 2014, Stenson 2014)

Table 3.1 Number of seals (harp, ringed and hooded) taken in Greenland between 2000 and 2009 and the proportion of skins sold to the tannery by hunters. (Source: Great Greenland A/S)

Table 3.2 Export of sealskins from Greenland and decline in value following announcement in 2006 of the then proposed ban on the import of seal products to the European Union. (Source: Great Greenland A/S, Exchange rate of 4.75 DKK to 1 USD)

Table 3.3 Estimates of the contribution of hunting to the informal economy of Greenland (millions of DDK or USD) (Source: Poppell 2006, Exchange rate of 4.75 DKK to 1 USD)

Table 4.1 Seals harvested in Norwegian coastal and marine areas 2008-2012.

Table 5.1 Estimated population numbers (x 1,000) of ringed, ribbon, spotted and bearded seals in the Okhotsk Sea between 1968 and 1990, based on aerial surveys. (Source: Trukhin 2009)

Table 5.2 Numbers of seals taken in commercial harvests in the Okhotsk Sea between 1955 and 2000. (Source: Trukhin 2009)

Table 7.1. Seal stocks in United States waters (Source: compiled from Allen \& Angliss 2013, Carretta et al. 2013, Waring et al. (2013)

Table 8.1 Annual Total Allowable Catch (TAC) for Cape fur seal pups and bulls from three rookeries on the Namibia coast. (Sources: Walters 2012b, Annual Reports of the Ministry of Fisheries and Marine Resources - MFMR)

Table 10.1 Summary of the main features of the legislative, regulatory and management approaches relating to seals in the countries included in this report.

Table 10.2 Summary of status and trends of the major seal populations covered in this report

Table 10.3 Summary of seal harvests and other mortality

Table 10.4 Summary of seal species population trends in different seas and perceived adverse impacts of seals on fisheries and of fisheries on seals

Table 10.5 Estimated biomass flow to mammals, birds, fish and fisheries in six ecosystems (Data from Bax 1991 in Yodzis 2001)

\section{List of Figures}

Figure 2.1 Harp seal range in the northwest Atlantic, migratory pathways and whelping locations. (Source: DFO 2014)

Figure 2.2 Estimated recent population trends of northwest Atlantic harp seals. The dotted lines indicate 95\% confidence intervals of the estimate, i.e. the solid line. (Source: DFO 2014).

Figure 2.3 Estimated population trends in northwest Atlantic grey seals. (Source: DFO Canada 2014) 
Figure 2.4 Value of landed pelts and total value of exported products (pelts, oils and meat) in Canada for 2004 to 2010. The landed value per pelt dropped from $\$ 97.4$ in 2006 to $\$ 10.9$ in 2010. (Value in Canadian \$, Source DFO 2010)

Figure. 7.1 Northern fur seal breeding colonies and the extent of their winter range. (Source: NMFS 2007) 


\section{INTRODUCTION}

Seals have been harvested and their resultant products (furs, oils and meat) used by humans for thousands of years (Bonner 1982, Rick and Erlandson 2008). However, large-scale commercial sealing is a comparatively recent development. It began in the $17^{\text {th }}$ century and reached a peak in the $19^{\text {th }}$ and early $20^{\text {th }}$ centuries. In the northern hemisphere, predominantly northern fur and harp seals were harvested. The primary products were pelts and oil. Annual catches exceeded 300,000 northern fur seals in the late 1860s, and more than 700,000 harp seals in the 1920s and 1950s. In the southern oceans, sealing for various fur seal species had collapsed by the 1920s, as a result of over-exploitation (Bonner 1982). Presently, sustainable commercial harvesting of seals (mainly harp seals) by Canada and Norway takes place in the east and west North Atlantic, and in the White Sea. Cape fur seals are harvested on the coast of Namibia. Indigenous peoples living in North Atlantic, North Pacific and arctic coastal areas harvest several species of seals. This harvest represents an integral component of both their household economies and culture (e.g. Nuttall and Callaghan 2000, Wenzel 2009, Harder and Wenzel 2012, Garde 2013). The primary objective of this study ${ }^{3}$ is to survey range state policies and management responses to growing or abundant seal populations.

Seals ${ }^{4}$, sea lions and walruses are marine carnivores that are classified as being within the sub-order Caniformia, which includes foxes, jackals, dogs, otters, weasels and polecats (as distinct from the other carnivore branch, the Feliformia, which includes hyaenas, cats, civets and mongooses). Unlike the cetaceans, seals are not entirely aquatic; they are tied to land or ice to breed and rest, readily exposing them to predation. Worldwide, there are 33 extant pinniped species of seals and sea lions that fall into three families; eared seals and sea lions (Family Otariidae with 14 species and 7 genera), walruses (Family Odobenidae with a single species only) and true seals (Family Phocidae with 18 species in 13 genera). Of the ten species and subspecies of fur seals assessed by IUCN in 2008, one was listed as endangered, one as threatened, and two as near threatened. Of the seven species and subspecies of sea lions three were endangered, one was vulnerable, and one was near threatened. Of the 27 species and subspecies of true seals, three were listed as critically endangered, two as endangered, and one as vulnerable (Kovacs et al. 2012). The remaining species are either data deficient or in expanding and/or abundant populations. Seals, along with whales, dolphins and porpoises, are top predators in coastal and oceanic ecosystems.

Following the earlier collapse of many pinniped populations, and their recent recovery, the commercial harvesting of seals has become a controversial issue. Animal rights and animal welfare organisations (e.g. Greenpeace, Humane Society International, Humane Society of the United States, International Fund for Animal Welfare (IFAW)) began intervening in commercial sealing operations in the 1970s, and have since supported major campaigns against sealing and the sale of seal products, particularly furs. These campaigns and the resulting hardening of public opinion against sealing resulted in prohibitions on the import of seal products in some places. In 1972, the USA banned imports of all seal commodities, when it passed the Marine Mammal Protection Act. In 1983 the Council of Ministers for the European Economic Community (a predecessor of the EU) imposed a ban on the importation of furs from baby harp and hooded seals (Royal Commission 1986a) that was extended to 1989. In 2009, the European Union enacted a ban on the import of all sealskins and any by-products of seals, including seal oil and related health products, while the Russian Federation ended its own commercial hunt in the same year, and banned imports of harp seal pelts in 2011 (Coulibaly 2010, Dauvergne and Neville 2011, Fink 2011, Kramer 2012, Hossain 2013). The ban on the importation of seal products into the European Union (EU) has been the subject of ongoing litigation involving adjudication by the World Trade Organisation,

\footnotetext{
3/ Terms of reference for this study are provided in Annex 1.

4 / In the context of this report "seals" refers to true seals and fur seals and excludes sea lions and walruses.
} 
which upheld the EU ban in early 2014. The bans have heavily impacted both commercial and subsistence sealing economies, and are examined later in relation to the country case studies, and in the concluding discussion.

This study reviews range state policy and management responses to expanding or abundant species of seals ${ }^{5}$; these are the Cape fur, northern fur, hooded, harp, ringed, grey, harbour and crabeater seals. Some of these species are harvested commercially (e.g. harp and Cape fur seals) and others are important in subsistence hunting by indigenous northern communities (e.g. northern fur, ringed, and hooded seals). There is also crossover between the groups, as in the case of the harp seal, which has proven important both commercially and from a subsistence perspective. Recovering grey and harbour seal populations are assuming increasing importance in potential conflicts with marine fisheries and coastal fish farming in both European and north-western Atlantic waters. Growing populations of harbour seals, in addition to sea lions, have created similar conflicts in the North Pacific.

The range states discussed in the scope of this report are Canada, Greenland, Norway, the countries of the European Union, Russia, United States of America, Namibia, and Antarctica. Commercial sealing is practised in Canada, Norway and Namibia. Subsistence hunting of seals among indigenous communities takes place in the USA, Canada, Greenland, Russia, as well as Sweden and Finland, which are members of the European Union. As mentioned earlier, the European Union, Russian Federation and the USA have all banned the import of seal products, and these policies have had impacts on those countries and individuals that harvest seals, whether commercially or for subsistence.

The potential for seal-fisheries conflict exists in all considered range states, except perhaps Antarctica, although the development of an expanding krill fishery may adversely impact crabeater seals and other marine mammals where krill forms a dominant component of their diet (Constable et al. 2000, Southwell et al. 2008). There is a long-standing perception amongst coastal fishers that seals compete with humans for available stocks of fish and bounty hunting of seals was a common practice in both Europe and North America (e.g. De Vooys et al. 2012, DeMaster and Sisson 1992). Recovering seal populations are also increasingly responsible for damaging fishing gear in coastal fisheries (e.g. Butler et al. 2011, Königson 2011). However, increased understanding of the complexity of marine food webs and the key role of top predators in marine ecosystem dynamics is serving to reinforce the importance of an ecosystems approach to managing seal-fisheries conflicts (e.g. Baum and Worm 2009, Tallis et al. 2010).

This review takes a case study approach regarding government seal management policies and practices, and examines the following additional issues within each country/species case study:

- Extra-territorial impacts of national or regional policies and management activities

- The nature and extent of perceived conflicts between seals and fisheries

- Economic and livelihood value of programmes for sustainable use of seals in the northern countries of Canada, Greenland, Norway, Russia, and the USA, and in the southern hemisphere, in Namibia.

An examination of the costs of seal management, such as for research, monitoring, law enforcement, and mitigating losses to fisheries, was included in the terms of reference but information at the level of detail required to meaningfully deal with this aspect was not available.

Each chapter provides a brief introduction to the current status and distribution of seals inhabiting the waters of each country and, where applicable, the levels of commercial and subsistence harvest and other human generated mortality, such as from fisheries bycatch. The chapter introductions are followed by an examination of government policy and available legal frameworks for harvesting or hunting seals, management plans and strategies, and official (gazetted) regulations governing the taking of seals.

5/ Terms of Reference for the study are provided in Annex 1. 
Economic and livelihood aspects of sealing are reviewed in countries where commercial and subsistence seal harvesting occurs. Perceived seal-fisheries conflicts are then outlined.

A final chapter provides a comparative synthesis of the key findings that emerge from the case studies and, in some instances, from additional literature.

\subsection{International conventions.}

The conservation, management, and hunting of seals are each governed at several levels; ranging from globally inclusive international conventions and agreements, such as the Convention on International Trade in Endangered Species of Wild Fauna and Flora (CITES), to more narrowly focused regional conventions, to nationally recognized laws and polices, and finally to local by-laws and cultural norms. The main international conventions influencing seal conservation and management are outlined or listed here, while national legislation and policies are covered separately in each of the country case studies.

The two primary international conventions governing conservation of biodiversity, the aforementioned CITES and the Convention on Biological Diversity (CBD), both make provisions for the sustainable use of fauna and flora, and have formally and explicitly endorsed the Addis Ababa Principles and Guidelines for Sustainable Use of Biological Diversity that provide clear guidance on sustainable use of living natural resources.

\subsubsection{CBD, sustainable use and the Addis Ababa Principles}

The three overarching objectives of the CBD are "the conservation of biological diversity, the sustainable use of its components and the fair and equitable sharing of the benefits arsing out of the utilization of genetic resources". Article 6 of the Convention "General measures for conservation and sustainable use" requires contracting parties to develop national strategies, plans, or programmes for the conservation and sustainable use of biological diversity. Guidelines for the application of these directives are provided in the Addis Ababa Principles and the in the Malawi Principles relating to the CBD guidelines on the Ecosystem Approach (see Annex 2 and Waylen et al. 2014) to managing living natural resources.

The fourteen Addis Ababa practical principles and guidelines are as follows:

1. Supportive policies, laws, and institutions are in place at all levels of governance, and there are effective linkages between these levels.

2. Recognizing the need for a governing framework consistent with international / national laws, local users of biodiversity components should be sufficiently empowered and supported by rights to be responsible and accountable for use of the resources concerned.

3. International and national policies, laws and regulations that distort markets, which contribute to babitat degradation, or otherwise generate perverse incentives that undermine conservation and sustainable use of biodiversity, should be identified and removed or mitigated.

4. Adaptive management should be practiced, based on:

a) Science and traditional and local knowledge;

b) Iterative, timely and transparent feedback derived from monitoring the use, environmental, socio-economic impacts, and the state of the resource being used; and

c) Adjusting management based on timely feedback from the monitoring procedures.

5. Sustainable use management goals and practices should avoid or minimize adverse impacts on ecosystem services, structure, and functions, as well as other components of ecosystems.

6. Interdisciplinary research into all aspects of the use and conservation of biological diversity should be promoted and supported. 
7. The spatial and temporal scale of management should be compatible with the ecological and socio-economic scales of the use and its impact.

8. There should be arrangements for international cooperation where multinational decision-making and coordination are needed.

9. An interdisciplinary, participatory approach should be applied at the appropriate levels of management and governance related to the use.

10. International and national policies should take into account:

i) Current and potential values derived from the use of biological diversity;

ii) Intrinsic and other non-economic values of biological diversity; and

iii) Market forces affecting the values and use.

11. Users of biodiversity components should seek to minimize waste and adverse environmental impact, and optimize benefits from uses.

12. The needs of indigenous and local communities who live with and are affected by the use and conservation of biological diversity, along with their contributions to its conservation and sustainable use, should be reflected in the equitable distribution of the benefits from the use of those resources.

13. The costs of management and conservation of biological diversity should be internalized within the area of management and reflected in the distribution of the benefits from the use.

14. Education and public awareness programmes on conservation and sustainable use should be implemented, and more effective methods of communications should be developed between and among stakeholders and managers.

\subsubsection{CITES}

Two often neglected CITES resolutions provide clear and explicit support for sustainable use and trade of plants and animals, as well as recognition that they can contribute to livelihoods of rural poor, and contribute to conservation. The first formal support for was contained in resolution Conf. 8.3 (Rev.

CoP13)* Recognition of the benefits of trade in wildlife, which resolved as follows:

THE CONFERENCE OF THE PARTIES TO THE CONVENTION

RECOGNIZES that commercial trade may be beneficial to the conservation of species and ecosystems or to the development of local people when carried out at levels that are not detrimental to the survival of the species in question; and

RECOGNIZES that implementation of CITES-listing decisions should take into account potential impacts on the livelihoods of the poor. (See Annex 3 for the full text of the resolution Conf. 8.3)

Further support by CITES for sustainable use was provided when Parties to the Convention were urged, in Resolution Conf. 13.2 (Rev. CoP14), to use the Addis Ababa Principles and Guidelines as is indicated in the following extracts from Resolution Conf. 13.2 (Rev. CoP14), which reads as follows:

\section{Sustainable use of biodiversity: Addis Ababa Principles and Guidelines}

WELCOMING the adoption at the seventh meeting of the Conference of the Parties to the Convention on Biological Diversity (CBD COP7), in Decision VII.12, of the Addis Ababa Principles and Guidelines for the Sustainable Use of Biodiversity, a summary of which is contained in Annex 1;

NOTING that these Principles and Guidelines can be utilized in the implementation by CITES Parties of Article IV and other relevant provisions of the Convention;

....... etc. (See Annex 3 for full text)

\section{THE CONFERENCE OF THE PARTIES TO THE CONVENTION}

URGES the Parties to:

a. make use of the Principles and Guidelines for the Sustainable Use of Biodiversity, also taking into account scientific, trade and enforcement considerations determined by national circumstances, as well as the recommendations of the 
Animals and Plants Committees (see Annex 2) when adopting non-detriment-making processes and making CITES non-detriment findings;

b. share experiences on sustainable use at the national level, particularly between CITES Management and Scientific Authorities, and their CBD Focal Points; and1 of 522/02/2012 11:45Resolution Conf. 13.2

c. endeavour to ensure that their CITES Management and Scientific Authorities participate, through their national CBD Focal Points, in the work of CBD and its Subsidiary Body on Scientific, Technical and Technological Advice (SBSTTA) on these Principles and Guidelines; and

URGES the Parties that are also Parties to the CBD, to take effective measures at policy and institutional level to ensure synergy between their implementation of CITES and CBD at the national level.

\subsection{Regional conventions, treaties and commissions}

The following conventions and treaties influence seal conservation and management:

The Convention for The International Council for the Exploration of the Sea (ICES)

Convention on The Conservation of Antarctic Marine Living Resources

Convention for The Conservation of Antarctic Seals (1972)

Convention for The Protection of The Marine Environment of The North-East Atlantic (also known as the OSPAR Convention)

Protocol on Environmental Protection to The Antarctic Treaty

Helsinki Convention - Baltic Sea

Bern Convention

Antarctic Treaty

And the following commissions were developed specifically for marine conservation and management purposes:

NAMMCO North Atlantic Marine Mammal Commission

Commission for the Conservation of Antarctic Marine Living Resources

Norwegian/Russian Joint Commission Working Group on Seals

ICES, although primarily concerned with fisheries, plays a particularly prominent role in the conservation and management of marine mammals. ICES was initially formed in 1902 with the exchange of letters between the original eight joining nations and the Convention was formally signed in 1964. Its activities are focused on the Atlantic Ocean with a strong emphasis on the North Atlantic where it provides advice on the management of marine living resources to its 20 member countries; namely, Belgium, Canada, Denmark, Estonia, Finland, France, Germany, Iceland, Ireland, Latvia, Lithuania, the Netherlands, Norway, Poland, Portugal, Russian Federation, Spain, Sweden, UK, and USA (See Article 1 of the Convention in Annex 3).

A key feature to emerge from an examination of the above international treaties, conventions and commissions is that they all include provisions for the sustainable use and management of living natural resources. However, member countries are at liberty to enact and enforce stricter measures regarding the protection of species within their waters and, as has happened in the European Union countries and others, implement bans on the importation and trade in seal products. 


\section{CANADA}

Canadian seal harvesting and management are centred in the Northwest Atlantic and focus on five species; harp (Pagophilus groenlandicus), hooded (Cystophora cristata), grey (Halichoerus grypus), ringed (Phoca hispida), and harbour (Phoca vitulina) seals. In the Canadian Pacific, northern fur seals overwinter in coastal areas, but have been assessed as "threatened" (COSEWIC 2010), and are protected under the Marine Mammal Regulations of the Fisheries Act, which protects the species against hunting or disturbance, except for subsistence use (DFO 2010). Harbour seals have not been legally hunted in British Columbia waters since 1967. Thus, the focus of this chapter is on the Canadian North Atlantic. The "2011-2015 Integrated Fisheries Management Plan for Atlantic Seals" (DFO 2010) fully describes government policy and management by the Department of Fisheries and Oceans Canada concerning this region.

Subsistence harvesting of seals by indigenous peoples occurs across northern Canada from Labrador in the east to the eastern Beaufort Sea in the west, and Canadian Inuit have co-management arrangements for wildlife populations (including seals) under land claims agreements.

\subsection{Seal population numbers and harvests}

Harp seals, with an estimated population of $\sim 7.4$ million, form the dominant component of the Canadian seal harvest (DFO 2012). The commercial harp seal harvest takes place off the coast of Newfoundland and in the Gulf of St. Lawrence region (Fig. 2.1) between mid-November and mid-June, with the majority of harvesting taking place between late March and mid-May. The breeding patches that form in March and the moulting patches that form in April-May are the primary harvest sites. The TACs and catches for the period 2001 to 2013 are shown in Table 1.

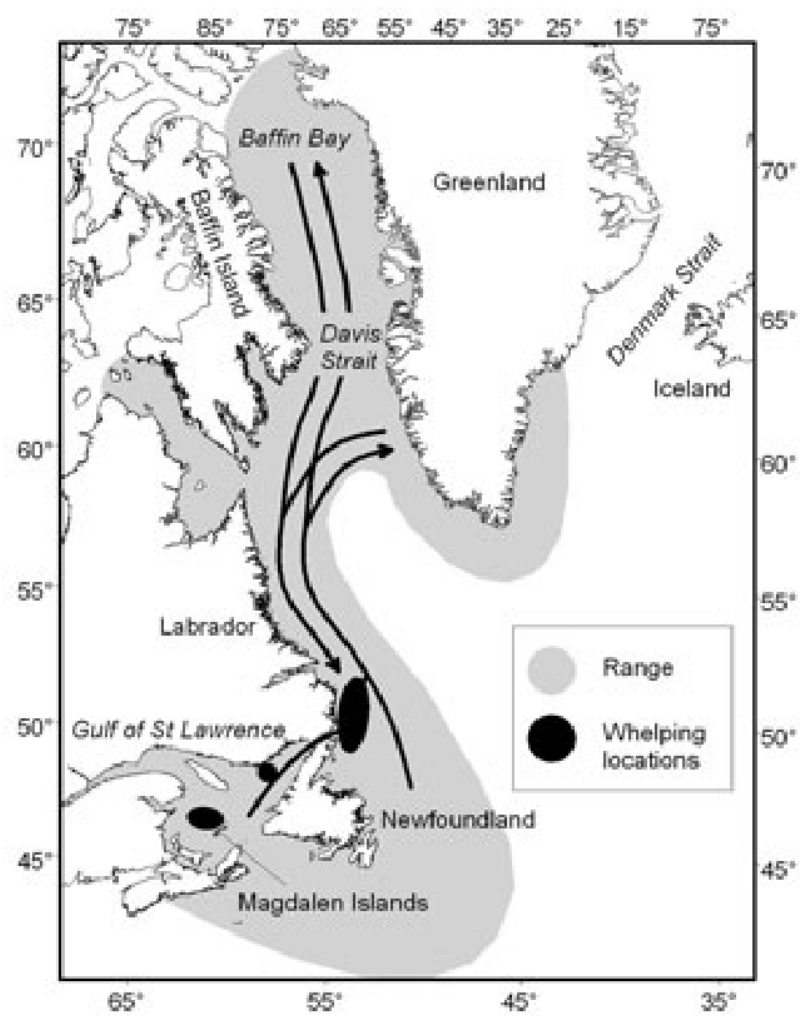


Figure 2.1 Harp seal range in the northwest Atlantic, migratory pathways and whelping locations.

(Source: DFO 2014)

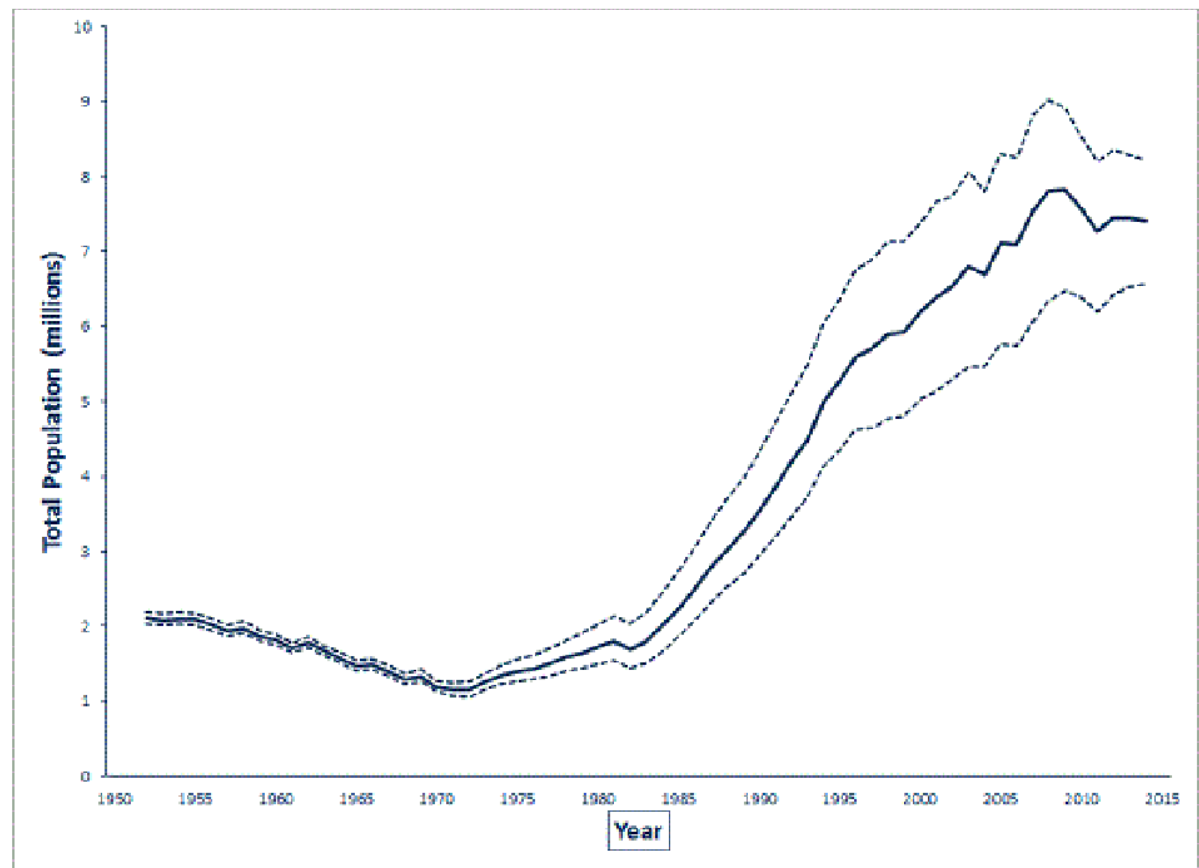

Figure 2.2 Estimated recent population trends of northwest Atlantic harp seals. The dotted lines indicate 95\% confidence intervals of the estimate, i.e. the solid line. (Source: DFO 2014).

Table 2.1 Total Allowable Catch (TAC), catch, and percentage of TAC taken for the Canadian harvest of harp seals and the Greenland harvest of harp seals (x 1,000). (Source: DFO 2012, M. Hammill and A. Rosing-Asvid in litt. September 2014, Stenson 2014)

\begin{tabular}{|l|r|r|r|r|}
\hline \multirow{2}{*}{ Year } & \multicolumn{3}{|c|}{ Canada } & Greenland \\
\cline { 2 - 5 } & TAC & Catch & \% Take & Catch \\
\hline 2001 & 275 & 226.5 & 80.9 & 85.4 \\
\hline 2002 & 275 & 312.4 & 113.6 & 66.7 \\
\hline 2003 & 350 & 289.5 & 82.7 & 66.1 \\
\hline 2004 & 350 & 366.0 & 104.6 & 70.6 \\
\hline 2005 & 319.5 & 323.8 & 98.7 & 91.7 \\
\hline 2006 & 335 & 354.9 & 105.9 & 92.2 \\
\hline 2007 & 270 & 224.7 & 83.2 & 82.8 \\
\hline 2008 & 275 & 217.8 & 79.2 & 80.6 \\
\hline 2009 & 280 & 76.7 & 27.4 & 71.0 \\
\hline 2010 & 330 & 69.1 & 20.9 & 90.0 \\
\hline 2011 & 400 & 40.4 & 10.1 & 74.0 \\
\hline 2012 & 400 & 71.5 & 17.9 & 78.6 \\
\hline 2013 & 400 & 90.7 & 22.7 & $\mathrm{n} / \mathrm{a}$ \\
\hline 2014 & 400 & 54.8 & 13.7 & $\mathrm{n} / \mathrm{a}$ \\
\hline
\end{tabular}

Note: For the period 2003-06, a multiyear quota was set at 975,000 seals (average 325,000 per year) with a maximum of 350,000 in any two years and the remainder in the third. A total of 985,312 animals were taken over the three years of this plan. (n/a - not available)

Although the TAC has been set at 400,000 since 2011, the proportion of the TAC taken each year since then has been less than $23 \%$. The percentage take has been low since 2009 , partly as a result of adverse weather conditions and partly as a result of reduced prices for seal products.

Harp seals are not listed by COSEWIC and their status in the IUCN Red List is 'Least Concern'. The population is estimated to have been $\sim 9$ million during the $18^{\text {th }}$ century after which it declined as a result 
of overharvesting to $\sim 1.5$ million between 1910 and 1970, after which it recovered to it present level of 7.4 million seals (DFO 2012).

Grey seals in the western Atlantic occur in the Gulf of St. Lawrence and off the shores of Quebec, New Brunswick, Prince Edward Island, Nova Scotia and Newfoundland. The population in 2014 was estimated to be $\sim 505,000$ animals (DFO 2014, Fig. 2.3). It has increased from an estimated population of about 30,000 animals in the 1970s. The annual commercial harvest has not exceeded 5,000 seals, although the TAC for 2009 and 2010 was 12,000. The TAC was increased for 2011 to 60,000, and has not been changed since 2011 (DFO 2014). For management purposes, the grey seal population is divided into three groups; Sable Island, coastal Nova Scotia, the Gulf of St. Lawrence.

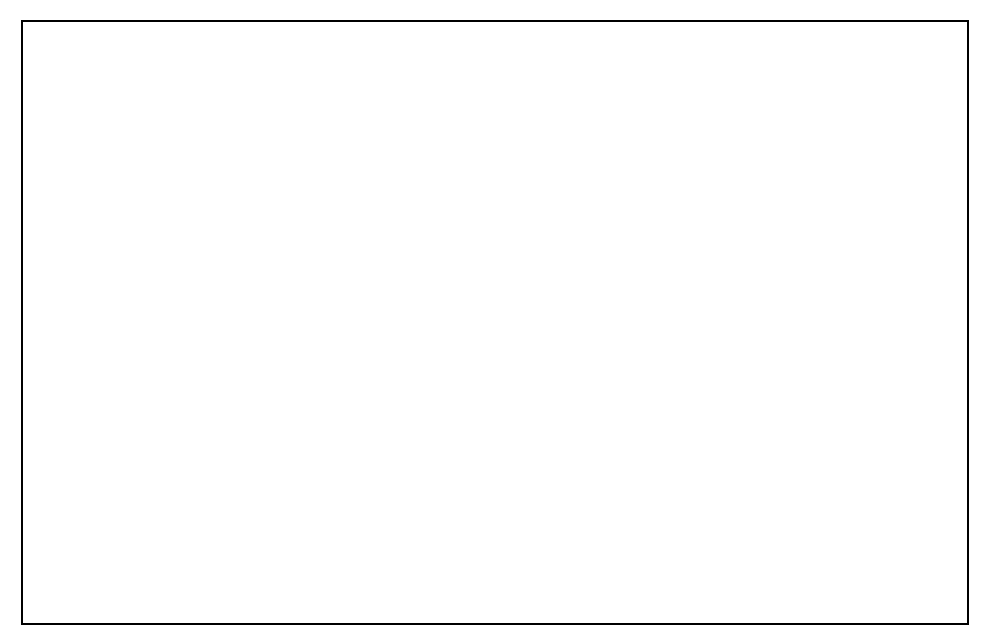

Figure 2.3 Estimated population trends in northwest Atlantic grey seals. (Source: DFO 2014). Dashed lines indicate $95 \%$ confidence intervals of the estimate - i.e. the solid line.

Grey seals are listed as "not at risk" by COSEWIC and their status in the IUCN Red List is that of "Least Concern'.

Hooded seals in the Northwest Atlantic occur in two distinct populations, one in Davis Strait west of Greenland and the other in Canadian waters in the Gulf of St. Lawrence and northern Newfoundland (an area known as "The Front"). The last population assessment for hooded seals in Canada was carried out in 2005 when the population was estimated to number 593,500 animals. (Fisheries and Oceans Canada 2014). The TAC was 8,200 for 2014 , and has remained at this level since 2007. Killing pups ("bluebacks") was prohibited in Canada in 1987 following a recommendation of the Royal Commission (1986a). The harvest of hooded seals has been very low (between 0 and 50) since 2006.

The species is classified as 'Vulnerable' by IUCN, and there is currently a zero quota for the population in the Greenland Sea north of Jan Mayen (i.e. the West Ice in Norwegian waters). Hooded seals are classified as "not at risk" in Canada by COSEWIC (Fisheries and Oceans Canada 2014).

Ringed seal numbers and trends in Canadian waters are poorly known. There is no commercial harvesting of ringed seals (DFO 2010). Information on subsistence harvest of ringed seal has been collected through various Arctic co-management organizations and institutions of public government, including the Nunavut Wildlife Management Board and Inuvialuit communities ${ }^{6}$. While statistics are incomplete, the annual subsistence harvest is estimated to be $\sim 1,500$ (DFO 2010).

6/ See e.g. http://www.beaufortseals.com/ and http://www.nwmb.com/en/cbmn. 
Ringed seals are listed as "not at risk" in Canada by COSEWIC (Fisheries and Oceans Canada 2014). Their status in the IUCN Red List is that of 'Least Concern'.

Harbour seals in the northwest Atlantic occur in the coastal waters of Nunavut, Manitoba, Ontario, Quebec, New Brunswick, Prince Edward Island, Nova Scotia, Newfoundland, and Labrador. The estimated number in Canadian waters is 20,000, and the species is classified as not at risk by COSEWIC (DFO 2014). Their status in the IUCN Red List is 'Least Concern'. Although a subspecies that lives in lakes in Quebec (P. v. mellonae) is listed as "endangered" by COSEWIC.

\subsection{Government policy and management of seals}

The constitution of Canada appears to be silent on matters relating to both the environment and the rights of citizens to a healthy environment (Boyd 2012). It is also silent on matters relating to sustainable use of renewable living resources. Inuit co-management of wildlife populations in areas covered by land claims agreements is embedded in land claims agreements protected by the Constitution.

The harvesting of seals in Canada is regulated through the Department of Fisheries and Oceans (DFO). DFO receives its mandate from the Minister of Fisheries and Oceans, whose authority is derived primarily from the Oceans Act, the Species at Risk. Act, and the Fisheries Act. The present governance, policy, and management of seals in Canada have been strongly influenced by the 1986 report of the Royal Commission on Seals and Sealing in Canada (Royal Commission 1986a, 1986b).

The Fisheries Act ${ }^{7}$ provides the legal basis for the management of fisheries and seals, assigning wide ranging discretionary powers to the responsible Minister. The definition of "fish" in the Act includes shellfish, crustaceans, and marine animals.

Section 6 [of the Act] refers to precautionary measures to be considered in respect of regulations made under the Act:

"FACTORS TO BE TAKEN INTO ACCOUNT

6. Before recommending to the Governor in Council that a regulation be made in respect of section ... [reference to several sections of the act $]$.... the Minister shall consider the following factors:

(a) the contribution of the relevant fish to the ongoing productivity of commercial, recreational or Aboriginal fisheries;

(b) fisheries management objectives;

(c) whether there are measures and standards to avoid, mitigate or offset serious harm to fish that are part of a commercial, recreational or Aboriginal fishery, or that support such a fishery; and

(d) the public interest. R.S., 1985, c. F-14, s. 6; 1991, c. 1, s. 2; 2012, c. 19, s. 135.

6.1 The purpose of section 6, and of the provisions set out in that section, is to provide for the sustainability and ongoing productivity of commercial, recreational and Aboriginal fisheries. 2012, c. 19, s. 135."

Section 43 [of the Act]: deals with the specifics of regulations that the Governor in Council may make for carrying out the provisions of the Act. These include regulations for the control of the sea, coast and inland fisheries and the conservation and protection of fish as defined under the Act.

The Marine Mammals Regulations " "pursuant to Section 8 and 43, subsection 87(2) of the Fisheries Act" provides for the issuance of licences, seal protection, observation of seal fishing, closed times and seasons, definition of fishing zones, and so on. The prohibitions governing the taking of seals are legally established and are quoted here in full because they have a direct bearing on the controversy regarding the Canadian commercial seal hunt.

PROHIBITIONS

7/ Consolidation Fisheries Act, R.S.C., 1985, c. F-14 Current June 12, 2014. http:/ /laws-lois.justice.gc.ca

8/ Consolidation Marine Mammal Regulations SOR/93-56 Current to June 12, 2014, Last amended on February 10, 2011. http://laws-lois.justice.gc.ca 
27. No person other than a beneficiary ${ }^{9}$ shall sell, trade or barter a whitecoat or blueback.

28. (1) No person shall fish for seals, for personal or commercial use, in any of Sealing Areas 4 to 33 except with:

(a) a round club made of hardwood that measures not less than $60 \mathrm{~cm}$ and not more than $1 \mathrm{~m}$ in length and that, for at least balf of its length, beginning at one end, measures not less than $5 \mathrm{~cm}$ and not more than $7.6 \mathrm{~cm}$ in diameter;

(b) an instrument known as a hakapik, consisting of a metal ferrule that weighs at least $340 \mathrm{~g}$ with a slightly bent spike not more than $14 \mathrm{~cm}$ in length on one side of the ferrule and a blunt projection not more than $1.3 \mathrm{~cm}$ in length on the opposite side of the ferrule and that is attached to a wooden handle that measures not less than $105 \mathrm{~cm}$ and not more than $153 \mathrm{~cm}$ in length and not less than $3 \mathrm{~cm}$ and not more than $5.1 \mathrm{~cm}$ in diameter;

(c) a rifle and bullets that are not full metal-jacketed that produce a muzzle velocity of not less than 1,800 feet per second and a muzzle energy of not less than 1,100 foot pounds; or

(d) a shotgun of not less than 20 gange and rifled slugs.

(1.1) No person shall use a club or hakapik to strike a seal older than one year unless the seal has been shot with a firearm.

(2) Every person who strikes a seal with a club or hakapik shall strike the seal on the top of the cranium until it has been crushed and shall immediately palpate the cranium to confirm that it has been crushed.

(3) If a firearm is used to fish for a seal, the person who shoots the seal or retrieves it shall palpate the cranium as soon as possible after it is shot to confirm that the cranium has been crushed.

(4) Every person who palpates the cranium of a seal and determines that the cranium is not crushed shall immediately strike the seal with a club or hakapik on the top of its cranium until the cranium has been crushed. SOR/2003-103, s. 6; SOR/2009-66, s. 2.

29. No person shall skin a seal until the cranium has been crushed and at least one minute has elapsed after the two axillary arteries of the seal located beneath its front flippers have been severed to bleed the seal. SOR/2003-103, s. 7; SOR/2009-66, s. 3.

30. No person shall fish for adult harp or hooded seals in whelping or breeding patches.

The 2011-2015 Integrated Fisheries Management Plan for Atlantic Seals (DFO 2010) provides a comprehensive and explicit statement of policy and management guidelines for the seal fishery in Canadian waters of the North Atlantic. The purpose of the plan is given as follows in the foreword:

"The purpose of this Integrated Fisheries Management Plan (IFMP) is to identify the main objectives and requirements for the Atlantic seal fishery, as well as the management measures that will be used to achieve these objectives."

The IMFP elaborates, inter alia, on the "three step process" for the humane harvesting of seals, outlines the stock assessment process for each species, the adoption of a precautionary approach to the management of seal populations, as well as the use of conservation and target reference points.

The main objectives of the management plan are to maintain healthy abundant seal populations and stable allowable catches, explore an ecosystem approach to managing seals, implement animal welfare standards, fully engage industry in the stewardship of the resource, involve society and ensure compliance with the regulations (Further details are provided in Annex 3).

\subsection{Issues relating to policy and practice}

\subsubsection{Animal welfare}

The humane killing of seals and the harvesting of harp seal pups in the "white coat" stage were highly controversial and formed the central focus of animal welfare, human rights, and anti-sustainable use campaigns against commercial sealing. To address the criticisms, government introduced new policies. They developed strict procedures for the killing of seals, introduced programs for the training and licensing of sealers, and initiated focused oversight by placing officially appointed and trained observers alongside sealers during actual commercial hunts. In addition, as the parts of the management plan

9 / Where "beneficiary" means a person who is a beneficiary under

(a) the Agreement approved, given effect and declared valid by the Western Arctic (Inuvialuit) Claims Settlement Act, or

(b) the Agreement approved, given effect and declared valid by the James Bay and Northern Quebec Native Claims Settlement Act; (bénéficiaire)" 
quoted above indicate, there are continuing efforts to develop more humane harvesting techniques (e.g. Daoust et al. 2011).

A study by Butterworth et al. (2007) for the Humane Society of the United States (HSUS), submitted to the European Food Safety Agency (EFSA) in 2007, and a subsequent review by Butterworth and Richardson (2013), concluded that "The review of available data indicates that generally accepted principles of humane slaughter cannot be carried out effectively or consistently in the commercial seal bunt." In essence, Butterworth and Richardson (2007) argued, on the basis of the evidence they presented from videos and post mortems, that the humane killing of seals on ice cannot be carried out as consistently as humane slaughter can be in an abattoir. Their view was not fully upheld by the EFSA (2007) report and findings, which concluded, inter alia, as follows (EFSA 2007, Summary pages 1-2):

\begin{abstract}
In relation to the killing methods, it was concluded that many seals can be, and are, killed rapidly and effectively without causing avoidable pain, distress, fear and other forms of suffering, using a variety of methods that aim to destroy sensory brain functions. However, there is strong evidence that, in practice, effective killing does not always occur but the degree to which it does not happen has been difficult to assess, partly because of a lack of objective data and partly because of the genuine differences in interpretation of the available data. When seals are hit or shot, but are not dead, they may have to be bit or shot again or may they be moved or skinned whilst conscious, resulting in avoidable pain, distress, fear and other forms of suffering. In addition, seals may be struck and lost with injuries that may cause suffering and affect their survival in the wild.
\end{abstract}

In a critique of the Butterworth and Richardson review, Daoust et al. (2014) argued that 'these authors' conclusions were incorrect because they were highly selective in their treatment of the information available and made no attempt to consider other perspectives", and that the paper "failed to provide an unbiased presentation of the available data and therefore did not bring further clarity to the debate on the Canadian commercial seal bunt". Daoust et al. (2014) also noted that Butterworth and Richardson had ignored the conclusions of the EFSA (2007) review and other reviews of the seal hunt, such as those by Smith et al (2005), and by the NAMMCO Expert Group (2009), on best practices in the hunting and killing of seals. The International Veterinarian Working Group (i.e. Smith et al. 2005) carefully analysed the various aspects of the seal hunt and concluded that the Canadian harp seal hunt "can be undertaken in a bumane manner, if done by competent and skilled professionals using the guidelines provided." The NAMMCO Expert Group (2009) reached similar conclusions but noted that while the methods applied in an abattoir could not be extended to the hunting of wild animals this did not mean that wild animals could not be killed humanely.

Butterworth and Richardson (2014) responded to the Daoust et al. (2014) critique and reiterated their conclusion that humane slaughter cannot be implemented in the context of commercial sealing.

\title{
2.3.2 Precautionary approach
}

Leaper et al. (2010) criticised the Canadian Government's implementation of the precautionary approach to the management of harp seals on the grounds that the management strategy had not been fully specified and tested, and was unlikely to meet its objectives. In response, Hammill and Stenson (2010) noted that the Objective-Based Fisheries Management Strategy being used to manage the Northwest Atlantic seal harvest was working well, and the 2011-2015 Management Plan explicitly includes provision for further work and adaptive responses to the management of the harp seal population. Harvesting levels since 2009 have been well below the official annual TACs, and the population of some seven million seals is not presently in danger of being overharvested. Total removals from the population for the period 2009-2013 averaged 148,788 harp seals, i.e. 2\% of the population of 7.5 million. During the decade before this the population was still growing while higher harvesting levels were taking place.

Management Strategic Evaluation (MSE) approaches that involve the full range of stakeholders and the use of biological, observation, assessment, and resource user models (e.g. Bunnefeld et al. 2011, Bunnefeld and Keane 2014, Fulton et al. 2014) do not appear to have been used in the management of fisheries or commercial seal harvests in the northwest Atlantic. 


\subsection{Seals and fisheries conflicts}

The present population estimate for grey seals in Eastern Canada is some 500,000 (Fig. 2.3), which, because it is a recovering coastal species, has raised concerns about grey seal predation and competition with commercial fisheries in the Gulf of St. Lawrence, particularly the recovery of cod stocks. The northwest Atlantic cod populations crashed in the early 1990s as result of overfishing and there are concerns that increasing resident grey seal numbers and the high, but migratory, harp seal population may inhibit the recovery of the cod fishery (DFO 2014). Earlier work based on modelling likely responses of target fish stocks to seal culls reached differing conclusions. Bundy (2001), using a trophodynamic model and concluded that while overfishing caused the collapse of cod stocks in the Labrador-Newfoundland ecosystem, harp seals were retarding their recovery. Morissette et al. (2006), using mass-balance models based on evaluating energetic pathways in food webs, suggested dominant predators such as harp, hooded and grey seals, had a negative effect on their prey. Recent modelling of the effects of environmental change and seal predation (Bousquet et al. 2014) on cod populations indicated that a significant reduction in seal populations (grey and harp seals), combined with reduced fishing, could lead to a recovery of cod stocks over a period of 20-30 years. However, as reported by Frank et al (2011), the trophic dynamics associated with the collapse and recovery of cod is very complex. The overfishing and collapse of the cod population resulted in a trophic cascade and regime shift associated with a $900 \%$ increase in planktivorous fish stocks that in turn preyed on juvenile stages of cod; a role reversal as adult cod were the former primary predator of planktivorous fishes. Planktivorous fish populations are now declining and there is an increasing potential for a recovery of predatory benthic fish populations, including cod (Frank et al 2011).

An additional concern for fisheries relating to the growth of grey seal numbers is the prevalence of sealworm, a nematode parasite (Pseudoterranova decipiens species complex) for which grey seals are a major final host (McClelland 2002). Sealworm larvae in harvested fish have to be removed, and degrade the value of the fish in the market. The debate related to grey seals and fisheries in Canadian waters is outlined in DFO 2010. Grey seal and fisheries conflicts are also emerging on the New England (USA) coast, as grey seals have recently moved into that region and their numbers are increasing.

\subsection{Economics of seal harvesting and livelihood issues in Canada}

There are two interrelated components to the economics of seal harvesting in Canada. One concerns the large-scale commercial seal harvest, while the other is related to subsistence hunting and the livelihoods and culture of Aboriginal peoples in northern Canada.

In the context of Canada's overall economy, the historical returns from sealing have been very low (Anonymous 2001a) and remain so. However, in the context of isolated communities and individuals living in remote coastal areas, the returns from sealing are "more significant than might be concluded from a narrow assessment of the direct costs of the bunt and the incomes earned from sealing" (Royal Commission 1986a). Sealing, in the northern parts of Newfoundland in "good" years, used to provide $20-30 \%$ of a sealer's total household income before the $1982 \mathrm{EU}$ ban came into effect. Importantly, returns from sealing were derived primarily through the late winter and early spring, when the funds could be used to invest in refurbishing fishing gear for the coming season. In addition, seals provided high quality food and clothing, and contributed to important cultural and social norms. The Royal Commission (1986b) report, Volume 2, provides an extensive review of the importance of seals to those living in the northern territories. It also notes the relationship between sealing and the Atlantic fishery, and comments on the impacts of the 1982 European Union ban on the import of sealskins.

Fisheries and Oceans Canada's 2011-2015 Integrated Fisheries Management Plan for Atlantic Seals outlines the current social, cultural and economic context of the commercial seal fishery (DFO 2010). 
The marked decline of the seal fur industry in Canada between 2006 and 2010 (Fig. 2.4) was primarily the result of two factors. One was the extent of ice formation in 2007 that resulted in poor harvesting conditions. The other was the declaration by the European Parliament in autumn 2006 which requested that the European Commission ban trade in seal products. The European Union passed the ban in 2009. Russia also banned the import of seal products in December 2011.

Research completed during the last decade and a half in the northern Inuit regions (Inuvialuit, Nunavut, Nunavik, and Nunatsiavut) has focused largely on the impacts of climate change and its effects on subsistence harvesting, the vulnerability of subsistence harvesting to this change, and nutrition. However, little research has focused on the economic aspects of climate change (Ford et al 2012) or on the effects of trade bans on seal products. The result is that recent data on the financial and economic impacts of the recent decline in the value of seal products for the northern regions, and the northwest Atlantic commercial seal harvest, are not readily available.

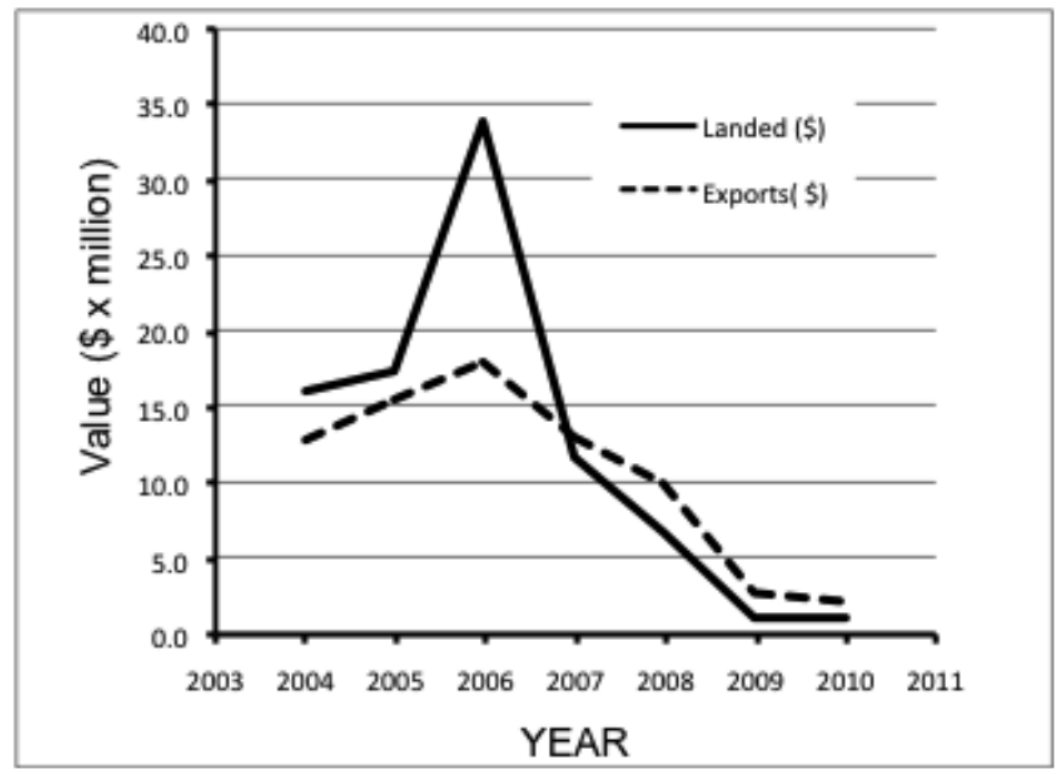

Figure 2.4 Value of landed pelts and total value of exported products (pelts, oils and meat) in Canada for 2004 to 2010. The landed value per pelt dropped from \$97.4 in 2006 to \$10.9 in 2010 . (Value in Canadian \$, Source DFO 2010)

In the northern Inuit regions of Canada, between $46 \%$ and $70 \%$ of households face either moderate or severe food insecurity (Council of Canadian Academies 2014). The causes are complex, but an important contributory factor is a decline in the ability of households to harvest country foods (e.g. Usher 2002). In part, this is a result of the centralisation of households into villages and towns, as well as the consequent decline in the use of dogs for transport (Usher 2002) and the resulting costs of using mechanical transport to hunt. Harvesting seals, and the sale of pelts that were surplus to household needs, contributed to both household food security and financing equipment for the effective harvesting of natural resources. In addition, the declining value of furs has also negatively influenced the development of hunting skills by younger Inuit (Council of Canadian Academies 2014). Seals have formed a central and important component of the cultural practice of food sharing in Inuit communities for generations. For example, marine mammal meat and fat was eaten, on average, 2.1 times per week, meat from land mammals 2.1 times per week and fish 2.7 times per week in 2004. Seals provided 59\% of marine mammal meat (Blanchet and Rosette 2008, Council of Canadian Academies 2014) for these populations.

The commercial sealing industry in Canada has been subsidised by the Federal and Newfoundland Governments that have taken the form of grants and loans to support aspects of the industry and the 
costs of regulating and monitoring commercial sealing operations (Anonymous 2001a). A more recent report by IFAW (2012) stated that the subsidy to the sealing industry in 2011 was at least $\$ 500,000$. 


\section{GREENLAND}

Seal hunting in Greenland occurs off the east and west coasts of the country, in the Davis Strait, Baffin Bay, and the Greenland Sea ${ }^{10}$. Three species form the major part of the seal harvest in Greenland waters; harp, ringed and hooded seals. Bearded seals (Erignathus barbatus) are also taken. Harbour and grey seals have been fully protected since December 2010 (Government of Greenland 2012a) because the former had been reduced to very low numbers and the latter only recently appeared in Greenlandic waters in 2009 and its status is not known.

\subsection{Seal population numbers and harvests}

Surveys of harvested seal populations inhabiting Greenlandic waters have not been conducted. However, the "Fact Sheet - Seals - Greenland" published by the Government of Greenland (2012b) provides the following information on seal numbers: there are more than 12 million seals in Greenland waters; the population of 8 million harp seals is shared with Canada; the ringed seal population in Baffin Bay is estimated to be 1.2 million seals; and the northwest Atlantic population of hooded seals is estimated to be 600,000 .

No quotas or TACs are set at a national level for seals in Greenland's waters. The distinction between subsistence and commercial hunting by licensed hunters is blurred. Harp and ringed seals formed $90 \%$ or more of the annual catch between 1993 and 2009, with an average of 79,206 ringed seals (range: 65,67692,063) and 77,830 harp seals (range: 56,886- 95,954) being taken each year (Data from Table 2 in Government of Greenland 2012a). Harp seals are hunted throughout the year, mostly in open waters, using rifles. Ringed seals are hunted on ice or in the water, with most being shot or being taken in nets. The average number of hooded seals taken between 1993 and 2009 was 5,867 (range: 1,986- 9,891). The average bearded seal take was 1,915 (range: 1,258 - 2,694) (Data from Table 2 in Government of Greenland 2012a).

\subsection{Government policy and management of seals}

Greenland is a self-governing country within the Kingdom of Denmark. Neither the Danish constitution, nor that of Greenland, refers to environmental rights or sustainable use of renewable natural resources.

Policy statements from official documents of both countries, however, show that the nations clearly support the full and sustainable use of renewable natural resources for the benefit of their people. This policy is clearly enunciated in the following paragraphs from the Kingdom of Denmark Strategy for the Arctic 2011-2020 (Kingdom of Denmark 2011).

- "All living resources must be developed and exploited sustainably based on an ecosystem management that ensures a bigh return in the long term, and is in compliance with international obligations, while at the same time the Arctic communities' rights are defended in support of the fishing and bunting industry. Management must be based on scientific advice that is founded on the collection, processing and analysis of data, including from bunters and industry.

- The Kingdom will work internationally for the Arctic indigenous peoples' right to conduct bunting and to sell products from seal bunting, as long as it is based on sustainable principles.

10/ Greenlanders have not particpated in the harp and hooded seal harvests in the Greenalnd Sea. These harvests have been carried out by Norway and Russia. 
- Denmark, Greenland and the Faroe Islands will work to ensure that the utilisation of living resources, including marine mammals, is founded upon an ecosystem-based management model that places emphasis on scientific foundation and sustainability.

- Work continuously to ensure regular scientifically based monitoring of living resources in the Arctic with the involvement of its citizens. The precautionary principle should apply in cases where there is a lack of adequate knowledge about development in previously ice- covered areas.

Subsequent paragraphs emphasise control of illegal fishing and hunting, international cooperation and regional controls on fisheries in large ecosystems.

The Greenland Ministry of Fishing, Hunting and Agriculture (Government of Greenland 2012a) paper on "Management and utilisation of seals in Greenland" provides further elaboration of the country's policy. In the foreword to the document the responsible minister has stated:

"As a Minister for Fisheries, Hunting and Agriculture, I have advocated intensively for increased sustainable use of all living resources in Greenland, based on sound biological advice."

The introduction to the report (Page 11) reinforces this policy:

"The hunting of seals is a vital component of everyday life and culture in Greenland. It provides a significant amount of nutritious food and income to families living in remote coastal communities. Harp, ringed and hooded seals are the three most important species; they are hunted in every settlement through the year as a one-man activity from small boats or by the use of sledge dogs. The skin is used as a part of the national suit and for bunting equipment. The fur is also used as a beautiful part of modern clothing and design.

Therefore, sealing and Greenland are inseparable."

Regulations governing seal hunting are based on the 1999 law on hunting and the 2003 law on the protection of nature and wildlife. The regulations outlined in the Government of Greenland (2012a) report (page 29) include the following relevant provisions:

1. Hunting of seals is managed by species through a dual permit system that covers both full time professional bunters and part time leisure hunting. Short-term trophy bunting and fishing permits can be issued to tourists.

2. Full time hunting permits are issued only to permanent residents for whom bunting is their primary source of income, i.e. at least $50 \%$ of their income is based on bunting and fishing.

3. Leisure bunting permits are issued to residents who must be at least 12 years of age.

4. No training or test is required to obtain a permit.

5. Permits must be renewed each year and no training or test is required to hold a permit.

6. Municipalities can use by-laws to restrict bunting to certain areas, seasons, and methods.

7. Hunters have to submit a catch report to the Ministry each year before a new permit is issued.

The country works closely with international organisations with regard to monitoring, harvesting and hunting methods, and research on seals in Greenlandic waters. These organisations include NAMMCO, ICES, and the North Atlantic Fisheries Organisation.

\subsection{Seals and fisheries conflicts}

Although there is no official policy in Greenland regarding the harvesting of seals to limit their impact on fisheries, there are some statements from officials that suggest existing seal harvests are an advantage in this respect.

The minister in her foreword to the "Seal management and utilisation in Greenland" alluded to the problem as follows:

"I would also like to stress the importance of a sound ecosystem based management of all living resources. The increasing numbers of seals in our seas are the biggest competitors to our fishermen and bunters." (Government of Greenland 2012a)

And Lynge (2013) referred to the problem in a presentation to the International Circumpolar Council as follows: 
- In many regions around the world including in Greenland waters, seal populations are creating ecosystem unbalance; they are threatening other species, destroying fishing gears and transmitting parasites to fish stocks;

- More than 15 million seals in the North Atlantic Ocean consume appr. 45,000 MT of fish and shellfish everyday;

While the claims on numbers of seals made by the Minister in Greenland and by Lynge (2013) may be questioned, the sentiments expressed provide an insight into the social and political drivers that may influence decisions regarding seal-fisheries conflicts and the harvesting of seals.

\subsection{Economics of seal harvesting and livelihood issues}

Seals form a central component of culture and livelihoods in Greenland (e.g. Garde 2013, Müller-Wille et al 2005, Nuttall et al. 2005). Lynge (2013), in his presentation as Chair to the International Circumpolar Conference, highlighted the current importance of seals as follows:

- Sealing in Greenland has always been and will continue to be a valuable socioeconomic activity for many bouseholds in Greenland;

- Up to early 1980's sealing has been an economically self sustaining activity which today has become a subsidized economy due to destroyed markets around the world.

The numbers of seals taken between 2000 and 2009 declined due to adverse sea ice conditions during 2002-2004, and then dropped again after 2006 in response to the impending ban on the import of seal products to the European Union (Table 1). There was a marked and rapid decline in the number of skins exported to the EU after 2006, and this was accompanied by a more than ten fold decline in the total value of skins exported, along with a $50 \%$ decline in the value of hides (Table 2 ).

Table 3.1 Number of seals (harp, ringed and hooded) taken in Greenland between 2000 and 2009 and the proportion of skins sold to the tannery by hunters. (Source: Government of Greenland 2012a)

\begin{tabular}{|r|r|r|r|}
\hline Year & Seals taken & $\begin{array}{r}\text { Skins } \\
\text { traded }\end{array}$ & $\begin{array}{r}\% \text { Sold to } \\
\text { tannery }\end{array}$ \\
\hline 2000 & 188,765 & 102,646 & 54 \\
\hline 2001 & 174,244 & 80,481 & 46 \\
\hline 2002 & 157,187 & 61,848 & 39 \\
\hline 2003 & 157,046 & 75,309 & 48 \\
\hline 2004 & 157,697 & 83,754 & 53 \\
\hline 2005 & 191,605 & 115,742 & 60 \\
\hline 2006 & 188,939 & 109,201 & 58 \\
\hline 2007 & 160,493 & 85,468 & 53 \\
\hline 2008 & 156,874 & 81,580 & 52 \\
\hline 2009 & 142,384 & 77,143 & 54 \\
\hline Average & 167,523 & 87,317 & 52 \\
\hline
\end{tabular}

The seal skin industry has since 2007 been supported by an annual grant of 1.06 million Euros from Denmark in the form of a service contract to Great Greenland A/S, the sole Greenland seal skin trading company. Subsidies of about USD 1,300 were paid directly to each commercial hunter in Greenland in 2008. The total subsidy in 2012 was DKK 25.7 million, with DKK 16 million being paid to hunters. Great Greenland A/S has depended entirely on the subsidy to purchase skins since 2007. The total number of licensed hunters in Greenland in 2007 was 8,180, and this figure had declined to 7,037 in 2011. That same year, professional hunters numbered 2,060. The company's turnover declined from 
DKK 63 million in 2005 before the EU ban, to 9.1 million in 2011 . The number of employees was reduced from 72 to 38 (Jessen 2012).

Table 3.2 Export of seal skins from Greenland and decline in value following the announcement in 2006 of the then proposed ban on the import of seal products to the European Union. (Source: Great Greenland A/S in Government of Greenland 2012a. Exchange rate of 4,75 DKK to 1 USD)

\begin{tabular}{|c|c|c|c|c|c|c|c|c|}
\hline Year & $\begin{array}{r}\text { No. } \\
\text { Skins } \\
\text { sold }\end{array}$ & $\begin{array}{r}\text { No. to } \\
\text { EU }\end{array}$ & $\begin{array}{l}\text { No. to } \\
\text { Others }\end{array}$ & Value DKK & DKK/Skin & USD/Skin & $\begin{array}{r}\% \text { to } \\
\text { EU }\end{array}$ & $\begin{array}{r}\% \text { to } \\
\text { Others }\end{array}$ \\
\hline 2004 & 115,723 & 82,163 & 33,560 & $45,477,000$ & 392.98 & 82.73 & 71 & 29 \\
\hline 2005 & 108,372 & 74,777 & 33,595 & $54,399,000$ & 501.97 & 105.68 & 69 & 31 \\
\hline 2006 & 91,026 & 60,077 & 30,949 & $59,681,000$ & 655.65 & 138.03 & 66 & 34 \\
\hline 2007 & 45,043 & 19,368 & 25,675 & $20,889,000$ & 463.76 & 97.63 & 43 & 57 \\
\hline 2008 & 31,307 & 5,009 & 26,298 & $11,132,000$ & 355.58 & 74.86 & 16 & 84 \\
\hline 2009 & 19,602 & 4,312 & 15,290 & $5,201,000$ & 265.33 & 55.86 & 22 & 78 \\
\hline 2010 & 23,167 & 6,023 & 17,144 & $5,760,000$ & 248.63 & 52.34 & 26 & 74 \\
\hline
\end{tabular}

The informal economy of subsistence hunting (of mammals, birds, and fish) in Greenland contributes substantially to household and national economies (Poppell 2006, Table 3). Consumption at the household level accounts for $35.4 \%$ of the value of harvested goods, with the balance being made up of gifts $(18.5 \%)$ private sales $(7.6 \%)$, and sales to restaurants, institutions and markets $(38.5 \%)$. Investment in equipment takes into account a need for boats, snowmobiles, dog sledges, and a variety of other items. In 2001, the contribution by hunters to Greenland's GDP was estimated at $1.3 \%$ of the total of 9,040 million DDK (Poppell 2006). The contribution per hunter to household income from hunting and fishing products amounts to about $42,000 \mathrm{DKK}$.

Table 3.3 Estimates of the contribution of hunting to the informal economy of Greenland (millions of DDK or USD) (Source: Poppell 2006, Exchange rate of 4.75 DKK to 1 USD)

\begin{tabular}{|l|r|r|}
\hline \multicolumn{1}{|c|}{ Economic component } & $\begin{array}{r}\text { Value } \\
\text { DKK }\end{array}$ & $\begin{array}{r}\text { Value } \\
\text { USD }\end{array}$ \\
\hline Contribution of professional hunters - Annual Average 1993-2002 & 130 & 27.4 \\
\hline Value of informal production by leisure time hunters - 2004 & 52 & 10.9 \\
\hline Variable costs for professional hunters and fishermen in equipment - 2004 & 153 & 32.2 \\
\hline Investments in equipment by hunters - 2004 & 265 & 55.8 \\
\hline Estimated sales value of informal economic activities by hunters 1993-2002 & 182 & 38.3 \\
\hline
\end{tabular}

The following statement from the Kingdom of Denmark, Greenland Home Rule Ministry of Foreign Affairs of 2008 served to emphasise the expected impacts of the European Union ban.

\section{"PROPOSAL FOR A REGULATION ON TRADE IN SEAL PRODUCTS}

- The seal hunt in Greenland is essential for the livelihood of more than 50\% of the population, either totally or partially. The bunt provides food for humans and dogs, especially in areas where subsistence bunt takes place. The sale of seal skins is often the only cash income available. The socioeconomic and cultural value of the bunt for Greenland is thus significant.

- Seal hunting performed by Greenlandic hunters is sustainable in view of the very great number of seals in the sea around Greenland. Approx. 8 million seals are present in these waters and only 160.000 seals are taken yearly - of which an average of 63.000 sealskins are exported (2004-2007). Presently no seal species in the North Atlantic can be found on the CITES lists of endangered species, which testifies to the sustainability of the hunt.

- The hunt is supported by regulations, monitoring and enforcement. Humaneness and considerations of animal welfare is at the centre of the Greenlandic seal hunt.

- Experiences from the1980s show that bans on seal skin products send a distinct message to consumers to avoid the product. 
The current proposal by the European Commission for a comprehensive ban of trade in seal products will severely impact the trade and might destroy the livelihoods of the Greenlandic sealers. Seal skins today trade at the lowest prices ever recorded due the stigmatisation of the bunt.

- As a consequence, the Kingdom of Denmark wishes to convey its deep concern in regards to the proposal for a regulation of the trade in seal skin products and the negative impact that this proposal will have for the Greenlandic society in general and for the seal hunters in particular."

More recent information on the impacts of the bans on seal products was not available. 


\section{NORWAY}

The marine zones falling under Norwegian jurisdiction, and in which seals are harvested and managed, include the Norwegian economic zone of 200 nautical miles off the coast of Norway, a fishery protection zone around Svalbard, and a fishery zone around Jan Mayen. There is also an agreement with the Russian Federation, under the Joint Norwegian-Russian Fisheries Commission and its working group on seals, which meets annually to examine and report on the management of seals in the Barents and White Seas. Six species of seals are, or have been, harvested within Norwegian waters; harp, hooded, harbour, grey, bearded, and ringed seals.

\subsection{Seal population numbers and harvests}

Harp seals are harvested in the West Ice (Greenland Sea off Jan Mayen) with an annual take of 5,000 to 8,000 from a population of about 350,000 (Table 4.1, Kovacs 2008, Øigård et al. 2014a). The population estimate in 2013 for the Greenland Sea was 627,410 animals (Norwegian-Russian Joint Commission 2013). Low numbers have been taken in the East Ice (i.e. the Barents Sea, see Table 1) where the population is estimated to be 1.36 million (Norwegian-Russian Joint Commission 2011). The seals from the West Ice and East Ice mix in the Barents Sea during non-breeding times, hence the joint management by Norway and Russia.

Harbour seals and grey seals are hunted in coastal areas, with an annual take of less than 1,000 harbour seals and fewer than 500 grey seals between 2008 and 2012 (Table 1).

Hooded seal. The northeast Atlantic hooded seal population has declined by $85-90 \%$ over the last few decades, and a zero quota for the commercial harvest has been in place since 2008 (Øigård et al. 2014b).

Table 4.1 Seals harvested in Norwegian coastal and marine areas 2008-2012.

\begin{tabular}{|l|r|r|r|r|r|r|}
\hline Year & $\begin{array}{r}\text { Hooded } \\
\text { Seal }\end{array}$ & $\begin{array}{r}\text { Harp Seal } \\
\text { (West Ice) }\end{array}$ & $\begin{array}{r}\text { Harp Seal } \\
\text { (East Ice) }\end{array}$ & $\begin{array}{r}\text { Harbour } \\
\text { Seal }\end{array}$ & Grey Seal & Total \\
\hline 2008 & 0 & 1263 & 0 & 900 & 458 & 2,612 \\
\hline 2009 & 402 & 8035 & 0 & 585 & 516 & 9,538 \\
\hline 2010 & 178 & 4768 & 115 & 159 & 363 & 5,583 \\
\hline 2011 & 21 & 10153 & 200 & 230 & 111 & 10,694 \\
\hline 2012 & 21 & 5593 & 0 & 355 & 64 & 6,038 \\
\hline 2013 & 22 & 16033 & 0 & - & - & 16,055 \\
\hline
\end{tabular}

Source: Norwegian Ministry of Marine and Coastal Affairs (2013) and Norwegian-Russian Joint Commission reports for 2011, 2012, 2013)

In 2005, the TAC set for the Greenland Sea harp seal was 15,000 for seals of one year of age and older (2 pups could replace 1 older seal). For the East Ice population, the TAC was set at 45,000. Of the 45,000, Norway was allocated a quota of 10,000 (Norwegian-Russian Joint Commission 2005). Seals from the White Sea breeding patches occupy the northern Barents Sea during the summer.

In 2013, the TAC allocated for harp seals in the Greenland Sea was 25,000 1+ animals (i.e. where 2 pups are counted as one $1 \mathrm{yr}+$ animal). This was considered to be a level of removal that would result in a $30 \%$ population reduction over a 10 -year period, suggesting a policy of reducing competition between seals and fisheries. On the recommendation of ICES, the TAC for the Barents and White Seas population was reduced to $15,8271 \mathrm{yr}+$ animals, and Norway was allocated a quota of 7,000 of which little has been taken. Since 2009 there has not been a Russian harvest in these seas. 


\subsection{Government policy and management of seals}

Norwegian government policy regarding the management of marine resources and seals is firmly based on principles of sustainable harvesting, and is explicitly reiterated in official government web pages that provide information on seals or a particular species of seal (Norwegian Ministry of Fisheries and Coastal Affairs 2013). For example, the page referring to the management of Norwegian coastal seals begins with the following statement:

"Harbour seals (Phoca vitulina) and grey seals (Halichoerus grypus) are the two seal species found on the Norwegian coast. Seals are important elements in the rich marine biodiversity of Norwegian waters. At the same time seal populations are also subject [to] an important part of Norway's sustainable use/ harvesting of marine resources. This combination of conservation and sustainable use is the core of Norway's management policy on seals."

The emphasis on sustainable use of marine resources is reflected in the country's Marine Resources Act ${ }^{11}$. Although the Act does not mention seals, the relevant sections are as follows:

Act relating to the Management of Wild Living Resources (Marine Resources Act)

\section{Section 1 Purpose}

The purpose of this Act is to ensure sustainable and economically profitable management of wild living marine resources and genetic material derived from them, and to promote employment and settlement in coastal communities.

\section{Section 2 Rights to resources}

Wild living marine resources belong to Norwegian society as a whole.

\section{Section 3 Substantive scope}

This Act applies to all harvesting and other utilisation of wild living marine resources and genetic material derived from them. Wild living marine resources means fish, marine mammals that spend part or all of their life cycle in the sea, plants and other marine organisms that live in the sea or on or under the seabed and that are not privately owned

\section{Section 7 Principle for management of wild living marine resources and fundamental considerations}

The Ministry shall evaluate which types of management measures are necessary to ensure sustainable management of wild living marine resources

Here the emphasis is placed on adopting the precautionary and ecosystem approaches, ensuring effective controls on harvesting, the allocation of resources to support employment and maintain coastal communities, optimum resource use in relation to markets and industries, reducing negative impacts of harvesting gear, and maintaining the material basis of Sámi culture (See Annex 3 for details).

The harp seal stocks are managed jointly by Norway and Russia and are assessed every second year by a working group under the auspices of ICES and the North-West Atlantic Fisheries Organisation (NAFO). Pup production, life history parameters, and catch statistics are used to model population sizes and provide the basis for ICES recommendations on annual quotas (Government of Norway 2013).

Harbour and grey seals are managed on an annual quota basis, with set hunting seasons that do not include the whelping period and are set according to the individual species annual breeding times by area along the coast. The rules for hunting seals by citizens and foreigners correspond to those governing biggame hunting in Norway.

Sealing is considered to represent sound resource management, and it is deemed necessary to harvest seals to maintain populations at desired levels. Arguments to support this policy quote figures proving that the tons of fish that are eaten by seals are equivalent to the entire annual herring catch by the

11/ Available at: http://www.fisheries.no/Publications/The-marine-resources-act/\#.VKAcu0A9rA 
Norwegian fleet (Norwegian Embassy, Azerbaijan, accessed 25/06/14). Policy support was extended to subsidising sealing on the basis that it contributed to sound environmental management (see section 4.4 below).

Animal welfare. Strict rules and detailed legislation govern sealing, with the existence of mandatory training for sealers, annual tests and training of sealers, and regulations governing the methods of killing and harvesting seals. An official copy of the Norwegian regulations governing sealing was not found. However, the EFSA (2007) report included details of these regulations and these are provided in Annex 3.

\subsection{Seals and fisheries conflicts}

Statements such as those equating the mass of fish eaten by seals with that harvested by an entire fishing fleet carry with them the notion that less predation by seals would result in more fish being available to harvest for human consumption. This simplistic view of predator-prey dynamics within what is an extremely complex marine food web is giving way, at least in scientific circles, to an appreciation of the role of top predators in moderating system dynamics and to an ecosystem approach to resource management that is reflected in some components of the Norwegian marine policy. The supposed impact of marine mammals on fisheries has also been challenged. For example Corkeron (2009) questioned the applicability of models of the Barents Sea fishery that suggested an unrealistic top down effect of minke whale and harp seal predation on the cod, herring and capelin fisheries. Alternative, more realistic models (Hjermann et al. 2004, 2007) have indicated a trivial effect of harp seal predation on fisheries. Similar conclusions have been drawn elsewhere - see section 5.3 under Russia and concluding discussion.

Corkeron (2006) has also criticised the Norwegian Ministry of Fisheries' approach to ecosystem based fisheries management.

\subsection{Economics of seal harvesting and livelihood issues in Norway}

The economics of seal harvesting in Norway will be affected by the removal of government subsidies to the industry in 2015. A recent press statement ${ }^{12}$ reported that the Norwegian parliament voted to remove the annual sealing subsidy of US $\$ 1.6$ million for the 2015 season. According to the report this amounts to a subsidy of about US\$ 136 per seal taken. Sealing was not banned, but will no longer be subsidised by government if this decision stands.

Subsistence hunting of seals in Norway is confined, if at all, presently to the northern county of Finnmark. The rights of coastal Sámi communities to harvest marine resources were examined by Pedersen (2012) in relation to historical codicils of the $18^{\text {th }}$ century and recent regulations that have progressively "denied local people both their indigenous and customary rights to live off marine based resources...". However, whether this finding will influence policy in relation to the subsistence use of marine resources in Finnmark remains to be seen.

12/ AFP 12 December 2014. http://www.businessinsider.com/afp-norway-scraps-controversial-seal-huntingsubsidy-2014-12?IR $=\mathrm{T}$ 


\section{RUSSIAN FEDERATION}

Seals occur in several regions off the coast of the Russian Federation. These are, from west to east, the Barents, White, Kara, Laptev, East Siberian and Chukchi seas in the circumpolar Arctic region, the Bering, Okhotsk, and Japan seas in the northwest Pacific region, and the Baltic and Caspian seas. In the circumpolar region, the key species hunted are harp seals and ringed seals in the White and Barents seas, (Norwegian-Russian Joint Commission, 2005), as well as ringed, bearded, spotted (Phoca largha) and ribbon seals (Phoca fasciata) in the Chukchi Sea (Hovelsrud et al. 2008), the latter group of species is hunted by indigenous Chukchi and Yup'iit peoples. Northern fur seals occur in the Bering Sea and Sea of Okhotsk where they were harvested at unsustainable levels during the $19^{\text {th }}$ and early $20^{\text {th }}$ centuries by the USA and Russia (Bonner 1982). Harbour and grey seals occur in the Baltic Sea. A small population of about 3,000 harbour seals was recorded in the Kuril Islands in 2000 (Trukhin 2009).

\subsection{Seal population numbers and harvests}

Recent information on annual TACs and catches, other than for the Barents Sea and White Sea ${ }^{13}$, has not been located for most of the Russian Arctic waters.

TACs for Russian waters are allocated for each species and each geographic region (Kovacs no date). For ringed seals in 2002, these allocations were: western Bering Sea 5,900; eastern Kamchatka 600; Sea of Okhotsk 28,000; Barents Sea 1,500 and; White Sea 1,100 (according to Government of the Russian Federation Decree 20 - November 2001 \# 1551). During the period from 1912 to 1933, maximum catches were much higher. The EFSA (2007) report included the following figures for annual quotas in 2005: ringed seals - 31,400 from the Bering, east Kamchatka and Okhotsk Seas and 3,800 in the Barents, Kara and White seas; harp seals - 45,000 in the White Sea of which 22,474 were taken; bearded seals 11,700 in the Bering, East Kamchatka and Okhotsk Seas and 800 in the Barents/White Sea.

Trukhin (2009) provides estimates of seal numbers between 1968 and 1990 in the Okhotsk Sea (Table 5.1) and the numbers of seals harvested in the Okhotsk Sea commercially between 1955 and 2000 (Table $5.2)$.

Table 5.1 Estimated population numbers $(\mathrm{x} 1,000)$ of ringed, ribbon, spotted and bearded seals in the Okhotsk Sea between 1968 and 1990, based on aerial surveys. (Source: Trukhin 2009)

\begin{tabular}{|r|r|r|r|r|}
\hline \multicolumn{1}{|l|}{ Year } & Ringed seal & Ribbon seal & Spotted seal & Bearded seal \\
\hline 1968 & 780 & 116 & 67 & 233 \\
\hline 1969 & 855 & 208 & 177 & 253 \\
\hline 1974 & 876 & 173 & 172 & 110 \\
\hline 1976 & 539 & 201 & 268 & 125 \\
\hline 1979 & 706 & 449 & 246 & 187 \\
\hline 1981 & 777 & 410 & 234 & 104 \\
\hline 1986 & 833 & 508 & 174 & 143 \\
\hline 1988 & 565 & 630 & 156 & 143 \\
\hline 1989 & 709 & 445 & 96 & 105 \\
\hline 1990 & 710 & 562 & 178 & 95 \\
\hline
\end{tabular}

Table 5.2 Annual numbers of seals taken in commercial harvests in the Okhotsk Sea between 1955 and 2000. (Source: Trukhin 2009)

13/ See summary of TACs and catches for these seas under the previous section on Norway 


\begin{tabular}{|r|r|r|r|r|r|}
\hline \multicolumn{1}{|c|}{ Year } & Ringed seal & Ribbon seal & Spotted seal & Bearded seal & \multicolumn{1}{c|}{ Total } \\
\hline 1955 & 72,517 & 9,384 & 1,987 & 6,562 & 90,450 \\
\hline 1960 & 98,310 & 3,444 & 9,264 & 5,202 & 116,220 \\
\hline 1965 & 83,448 & 5,152 & 3,996 & 4,737 & 97,333 \\
\hline 1970 & 30,386 & 5,213 & 4,618 & 3,127 & 43,344 \\
\hline 1975 & 19,188 & 3,500 & 3,937 & 1,435 & 28,060 \\
\hline 1980 & 5,898 & 3,451 & 1,689 & 1,616 & 12,654 \\
\hline 1985 & 17,248 & 10,000 & 6,846 & 2,959 & 37,053 \\
\hline 1990 & 23,372 & 14,695 & 7,352 & 4,639 & 49,058 \\
\hline 1995 & 284 & 0 & 132 & 101 & 517 \\
\hline 2000 & 196 & 18 & 976 & 190 & 1,380 \\
\hline
\end{tabular}

Belikov and Boltunov (1998) reviewed the ecology of ringed seals in the western Russian Arctic, and provide details of the annual numbers of ringed seals harvested in the Barents, Kara and White seas between 1903 and 1994. The maximum number of ringed seals taken in any one year from these seas during this period was 8,912 from the White Sea during 1912, 13,517 from the Barents Sea during 1962, and 13,200 from the Kara Sea during 1933. Data on annual subsistence harvests are not available.

Recent statistics for areas, other than for harp seals in the Barents and White Seas, do not appear to be available (V. Burkanov, personal communication, 2014).

The Government of the Russian Federation implemented a ban on taking harp seal pups in 2009, and this has been upheld to the present (Norwegian-Russian Joint Commission 2013). Belyakova (2009) provides a comprehensive review of changes in sealing in the Arkhangelsk region of Russia from medieval times through to 2007, complete with an analysis of the conflict between sealing and animal rights activists in Russia, and the consequences of the ban on commercial seal harvests. In a development that was restricted to Russia, seal farms were opened in Koida, at the entrance to the White Sea. Harp seal "grey coats" were captured on the ice and ferried by helicopter to fenced enclosures in which they were kept until ready for slaughter as beaters. This practice was initially tried experimentally in 1971, and then continued through until 1995 when the seal farm closed as a result of escalating costs related to helicopter operational costs. At its peak, 10,000 to 17,500 animals were kept in farm enclosures each year (Belyakova 2009).

\subsection{Government policy and management of seals}

Documents regulating the conservation and management of seals in the Russian Federation have not been found. The authors of the EFSA (2007) were also not able to find any regulations governing the hunting of seals in Russian waters.

Russia was a major importer of seal pelts ${ }^{14}$, and the 2011 ban on the import of seal products to the Russian Federation has resulted in marked additional extra-territorial impacts on the Canadian and Greenland seal harvests and markets.

\subsection{Seals and fisheries conflicts}

Arneberg et al (2013) refer to the small size of the polar cod (Boreogadus saida) stock in the Barents Sea and the apparently high mortality rate. They suggest that this may be a result of predation by cod (Gadus morbua), the stocks of which are at their highest recorded biomass in the Barents Sea, and different

\footnotetext{
14 / According to IFAW, Russia received 90\% of the Canadian export of seal skins. http://www.ifaw.org/united-
} states/news/major-victory-russia-bans-trade-harp-seal-skins 
species of seals. There is apparently no suggestion that the harp seal population, the largest of the seal populations in the Barents Sea is adversely impacting cod.

\subsection{Economics of seal harvesting and livelihood issues}

Recent information on this subject was not available for the Russian Federation. 


\section{EUROPEAN UNION COUNTRIES}

The EU countries that have seals are those with coastal areas on the eastern Atlantic Ocean north of $45^{\circ}$, and shores that border the Bay of Biscay (France and Portugal), the Irish Sea (Ireland, Northern Ireland, Wales and Scotland), the English Channel (France, England and Belgium), the North Sea (Netherlands, Germany, Denmark, England and Scotland) and the Baltic Sea (Germany, Denmark, Sweden, Poland, Lithuania, Latvia, Estonia, and Finland). Russia also borders on the Baltic Sea, but is not part of the Union. Policies and legal frameworks governing the conservation and management of seals are, for the most part, regulated under the Bern Convention and the EU Habitats Directive, or in the case of the Baltic Sea, by the Helsinki Convention. The OSPAR Convention also influences seal conservation but mainly through its influence in mitigating pollution of maritime areas. Nevertheless, there are national and bilateral seal management plans (e.g. Sweden, and the tripartite management plan for seal in the Wadden Sea involving Netherlands, Germany and Denmark) and specific national legal frameworks that merit attention, such as the Marine (Scotland) Act. Key issues in the region involve providing for the conservation and recovery of depleted seal populations, while dealing with conflicts between fisheries and increasing seal populations, particularly of grey seals in the Baltic Sea and Scottish waters.

Only three species are present in these waters, harbour, grey and ringed seals. Their numbers, as compared with those in the northwest Atlantic, are low. Accordingly, in broad terms, the emphasis within the EU is on supporting the recovery of seal populations, finding ways to reduce associated increases in seal-fisheries conflicts, and establishing protected areas. Legislation and policy instruments at regional and national levels retain the option to control seal numbers should the need arise.

\subsection{Seal population numbers and harvests}

Harbour seals (Phoca vitulina vitulina). Population status varies throughout its range within the European Union, and an overall estimate of the current population number is not available. This species is protected and there is no subsistence or commercial harvest, although licensed killing to protect fisheries is permitted in United Kingdom's (UK) waters. As a result of seal bounty hunting over centuries (e.g. De Vooys et al. 2012) and high levels of hunting in the early $20^{\text {th }}$ century, harbour seal populations were greatly depleted by the 1950s. Following protection in the 1970s, populations are recovering, but periodic outbreaks of phocine distemper have caused major die-offs in parts of their European range (e.g. Thompson and Härkönen 2008a).

Grey seals. Two subspecies in Europe are recognised, Halichoerus grypus grypus in the eastern Atlantic and Halichoerus grypus macrorynchus in the Baltic Sea. The eastern Atlantic population is concentrated around Ireland and Scotland, but this subspecies also occurs along the European coast from southern France to the Kola Peninsula, and the White Sea and Pechora Sea in north-western Russia (Thompson and Härkönen 2008b, Lydersen et al. 2012). Baltic grey seal numbers were estimated at 27,500 in 2007, while the eastern Atlantic population was estimated at between 117,000 and 171,000 animals (Thompson and Härkönen 2008b), 80\% of which occurred in Scottish waters (SCOS 2013). Both the Baltic Sea and the eastern Atlantic Sea populations have been growing at about 10\% per annum (Anonymous 2007b, SCOS 2013).

Ringed seals. In Europe, apart from occasional vagrants in the North Sea and east Atlantic, ringed seals of the Baltic subspecies (Pusa hispida botnica) are confined to the Baltic Sea with two further subspecies found in Lakes Saimaa (P. h. saimensis) and Ladoga (P. h. ladogensis). From an estimated $\sim 200,000$ seals in 1900, the Baltic population declined to about 5,000 in the 1970s (Harding and Härkönen 1999) as a result 
of both overhunting and the effects of pollution on reproductive disorders and disease (Anonymous $2007 \mathrm{~b}$ ). The main population in the Gulf of Bothnia has been growing at about $5 \%$ per annum since 1990 (Anonymous 2007b).

\subsection{European Union policy and management of seals}

Given the historical development of conservation related conventions affecting Europe and the integration of 27 nations into the European Union, the establishment of overlapping jurisdictions at different scales has been inevitable. This section will discuss firstly the larger scale legal and policy frameworks affecting seals, such as the European Habitat Directive, the Bern Convention and the Helsinki Convention and its Commission (HELCOM). Covering the legal and policy frameworks of all $27 \mathrm{EU}$ countries is beyond the scope of this review, but two areas in which grey seal populations are increasing rapidly and giving rise to conservation and management conflicts are discussed. These two areas are Scotland, where recent comprehensive legislation provides an example of current policy development, and the Baltic Sea focusing on Finland and Sweden, where seal-fishery conflicts are an issue.

\subsubsection{European Habitats Directive}

The European Habitats Directive (COUNCIL DIRECTIVE 92/43/EEC of 21 May 1992 on the conservation of natural habitats and of wild fauna and flora - as amended up until 200715) provides an overarching framework for the conservation of habitats and species within the countries comprising the European Union. The directive required all countries to implement appropriate national level legislation within two years to support the implementation of the Directive. The following excerpts from the Directive relate to the conservation of seals within the EU countries.

\footnotetext{
Article 2

1. The aim of this Directive shall be to contribute towards ensuring bio-diversity through the conservation of natural habitats and of wild fauna and flora in the European territory of the Member States to which the Treaty applies.

2. Measures taken pursuant to this Directive shall be designed to maintain or restore, at fa vourable conservation status, natural habitats and species of wild fauna and flor of Community interest.

3. Measures taken pursuant to this Directive shall take account of economic, social and cultural requirements and regional and local characteristics.
}

"Favourable" in respect of a species is defined as follows (Article 1, Definitions - Page 5):

(i) conservation status of a species means the sum of the influences acting on the species concerned that may affect the long-term distribution and abundance of its populations within the territory referred to in Article 2;

The conservation status will be taken as 'favourable' when:

- population dynamics data on the species concerned indicate that it is maintaining itself on a long-term basis as a viable component of its natural habitats, and

- the natural range of the species is neither being reduced nor is likely to be reduced for the foreseeable future, and

- there is, and will probably continue to be, a sufficiently large babitat to maintain its populations on a long-term basis;

Species of "Community interest' refers to those that are endangered, vulnerable, rare, or endemic and that may be listed in Annex II, IV or V. Harbour, grey and ringed seals are listed in Annex II (Page 24). Matters dealing with the protection of species and taking of wild specimens that have a bearing on seals are covered in Articles 14 and 15 of the Directive (See Annex 3).

Although the three species of seals are listed on Appendix II, the EU Habitats Directive does not preclude the sustainable use of seal populations, provided they are maintained at a "favourable conservation status", and the conditions pertaining to the take, as detailed in Articles 14 and 15, are met.

15/ Availabel from: http://ec.europa.eu/environment/nature/legislation/habitatsdirective/index_en.htm 
Additional conventions and agreements that bear on national policy in relation to the conservation and management of seals within the EU include the Bern Convention of 1982, the Helsinki Convention on the Protection of the Marine Environment of the Baltic Sea of 1974, and the OSPAR Convention.

\title{
6.2.2 The Bern Convention
}

The Convention on the Conservation of European Wildlife and Natural Habitats - the Bern Convention, was signed in December 1979, and came into force in 1982. It applied to the European continent and to some countries in Africa. The following extracts from the convention provide the context in which the convention applies to seals in Europe.

\section{Chapter I-General provisions Article 1}

1. The aims of this Convention are to conserve wild flora and fauna and their natural habitats, especially those species and habitats whose conservation requires the co-operation of several States, and to promote such co-operation.

2. Particular emphasis is given to endangered and vulnerable species, including endangered and vulnerable migratory species.

Chapter III of the convention provides for the protection of species with articles 6 to 9 specifying the actions to be taken countries in relation to species listed in one of three appendices. The measures cover specific actions to be taken to ensure the special protection of listed species. Article 6 to 9 are included in Annex 3.

The seal species listed in the Appendices to the Convention are as follows:

$\begin{array}{lll}\text { Appendix II: Phocidae } & \text { Appendix III: Phocidae } & \\ \text { Monachus monachus } & \text { Cystophora cristata } & \text { Phoca vitulina } \\ \text { Phoca hispida saimensis } & \text { Erignathus barbatus } & \text { Halichoerus grypus } \\ \text { Phoca hispida ladogensis } & \text { Pagophilus groenlandicus } & \end{array}$

As in the EU Habitats Directive, provisions for the sustainable harvesting of wild populations are included, as is the provision for killing seals to protect fisheries.

\subsubsection{The Helsinki Convention and the Baltic Sea}

Although primarily concerned with environmental pollution of the Baltic Sea, Article 15 of the Helsinki Convention provided for conservation of the nature and biological diversity of the Baltic Sea.

\begin{abstract}
Article 15
Nature conservation and biodiversity

The Contracting Parties shall individually and jointly take all appropriate measures with respect to the Baltic Sea Area and its coastal ecosystems influenced by the Baltic Sea to conserve natural habitats and biological diversity and to protect ecological processes. Such measures shall also be taken in order to ensure the sustainable use of natural resources within the Baltic Sea Area. To this end, the Contracting Parties shall aim at adopting subsequent instruments containing appropriate guidelines and criteria.
\end{abstract}

In 1988 HELCOM issued a recommendation specifically for the protection of seals:

RECOMMENDS that the Governments of the Contracting Parties to the Helsinki Convention:

a) through their national instruments ban all hunting of grey seals, ringed seals and harbour seals in the Baltic area. In order to safeguard the survival of these species, the ban shall be maintained until a natural health condition and a normal reproductive rate can scientifically be shown;

b) make efforts to establish seal sanctuaries and, when appropriate, organize seal breeding in order to save the genetic individuality of the declining Baltic seal stocks,

This recommendation was superseded by a more comprehensive recommendation on the conservation and management of the three species of seals in the Baltic Sea in Recommendation 27-28/2 of 2006. The recommendation noted general management principles, specific population reference levels, and distinct seal management units within the Baltic Sea, some which applied to specific countries. The text of the contracting parties recommendation is provided in Annex 3. 
The Convention provides for the sustainable harvesting of seals where populations have reached, or have exceeded, target reference levels.

\subsubsection{The Bonn Convention - Migratory Species Convention}

The Convention includes Mediterranean monk seals in Appendix I, and affords them complete protection. Signatory range state countries are required to develop joint management plans for species listed in Appendix II, which only applies the Baltic and Wadden Sea harbour seal populations and the Baltic Sea grey seal population. These joint management plans are also required for harbour seals in the Wadden and Baltic seas, and for grey seals in the Baltic Sea. The three countries managing the Wadden Sea (Denmark, Germany and Denmark) have, within the framework of the Bonn Convention, implemented management plans for harbour and grey seals.

\subsubsection{The OSPAR Convention ${ }^{16}$ - Convention for the Protection of the Marine Environment of The North-East Atlantic}

The primary focus of the Convention is on conserving and protecting the marine environment and the fauna and flora it supports with an emphasis on issues of environmental pollution and sustainable management of the maritime area. It replaces the original Oslo and Paris conventions that did not adequately control many sources of marine pollution. The primary articles of the Convention deal with pollution (Articles 3-7), with scientific and technical research (Article 8), and with implementation and administration of the Convention. Conservation matters are dealt with in ANNEX V "On The Protection and Conservation of The Ecosystems and Biological Diversity of the Maritime Area" (See Annex 3). Definitions of biodiversity, ecosystems and habitats follow those of the CBD. A primary concern of the Convention in relation to conservation is to "protect the maritime area against adverse effects of human activities so as to safeguard human health and conserve marine ecosystems" and to aim for an integrated ecosystem approach in managing marine areas.

\subsubsection{The British Isles}

\subsubsection{United Kingdom}

The UK Marine policy statement ${ }^{17}$ provides an overarching statement of intent as indicated here:

"The MPS will facilitate and support the formulation of Marine Plans, ensuring that marine resources are used in a sustainable way in line with the high level marine objectives 3 and thereby:

- Promote sustainable economic development;

- Enable the UK's move towards a low-carbon economy, in order to mitigate the causes of climate change and ocean acidification and adapt to their effects;

- Ensure a sustainable marine environment which promotes healthy, functioning marine ecosystems and protects marine habitats, species and our heritage assets; and

- Contribute to the societal benefits of the marine area, including the sustainable use of marine resources to address local social and economic issues."

However, this document and related documents are silent on seals, other than to state in a footnote that the Seal Act of 1970 governs the management of seals, which it still does for England and Wales. It has been superseded in Scotland by the Marine (Scotland) Act of 2010.

\subsubsection{Scotland}

According the UK Special Committee on Seals (SCOS), 38\% of the global population of grey seals breed in the UK, and of this number $88 \%$ breed at colonies in Scotland where the main concentrations are in the Outer Hebrides and Orkney Islands (SCOS 2013). The overall UK population is estimated to be

16/ http://www.ospar.org/content/content.asp?menu=01481200000000_000000_000000

17/ https://www.gov.uk/government/publications/uk-marine-policy-statement 
between 90,000 and 140,000. The UK population of $\sim 37,000$ harbour seals is similarly concentrated in Scottish waters.

The Marine (Scotland) Act of $2010^{18}$ covers the Scottish marine area and is introduced on the Scottish Government website as follows:

"The Marine (Scotland) Act provides a framework which will help balance competing demands on Scotland's seas. It introduces a duty to protect and enhance the marine environment and includes measures to help boost economic investment and growth in areas such as marine renewables.

The main measures include:

- Marine planning: a new statutory marine planning system to sustainably manage the increasing, and often conflicting, demands on our seas

- Marine licensing: a simpler licensing system, minimising the number of licences required for development in the marine environment to cut bureaucracy and encourage economic investment

- Marine conservation: improved marine nature and historic conservation with new powers to protect and manage areas of importance for marine wildlife, habitats and historic monuments

- Seal conservation: much improved protection for seals and a new comprehensive licence system to ensure appropriate management when necessary

- Enforcement: a range of enhanced powers of marine conservation and licensing"

Part 6 of the Act (pages 71-78) discusses, in some detail, the conservation and management of seals in Scottish waters and repeals, in Section 130, the Conservation of Seals Act 1970 (c.30). The opening statement to Part 6 of the Act, Section 107, states, "Killing, injuring or taking a live seal (intentionally or reckelessly) is an offence". The following Sections (i.e. 108 to 112 see Annex 3) deal with exceptions to Section 107 such as killing or taking a seal to alleviate suffering, killing or taking a seal under licence, the conditions under which licences to kill or take a seal may be granted, the methods of killing allowed, and the conditions under which licences may be issued.

Despite the tightly controlled conditions under which licenses may be issued, the Act clearly makes provision for the killing of seals to protect fisheries. Section 110 (j) makes provision for the harvesting of seals for ecological and economic reasons, should these arise, and thus makes provision to sanction sustainable use of seals in line with the overarching policy of sustainable use of marine resources.

\subsubsection{Finland}

Finland adheres to the policy and legal requirements of the Convention on Biodiversity, the Bern Convention, the Bonn Convention, and the Helsinki Convention and HELCOM recommendations. Finland also follows the EU legislation in respect of the conservation and management of seals (EU Habitats Directive, Water Framework Directive, and EU related strategies on marine resources, sustainable development, and biodiversity; Anonymous 2007a). Finland's 96 page "Management Plan for the Finnish Seal Populations in the Baltic Sea" notes that the management of seal populations is subject to two sets of legislation, one being the legislation of the mainland, the other being that of the independent province of Åland. The Baltic ringed seal and grey seal are classified as game species, and are subject to the Hunting Act administered by the Ministry of Agriculture and Forestry and the Ministry of Environment. The conservation of wildlife and threatened and endangered species, such as the Saimaa ringed seal, is governed by the Nature Conservation Act, which is administered by the Ministry of Environment. The following outline of the regulations governing the hunting of seals is taken from the seal management plan (Anonymous 2007b).

"Hunting means the capturing and killing of wild game animals as well as utilising the bag by the bunter (section 2 of the Hunting Act). According to section 20 of the Act, bunting must be practised in accordance with the principles of sustainable use and so that game populations are not endangered. Grey and Baltic ringed seal may be bunted under the Act during specific bunting seasons with a bunting licence. In mainland Finland, the present annual bunting season is between 16 April and 31 December for the grey seal and 1 September and 15 October and 16 April and 31 May for the Baltic ringed seal. Licences have been issued

18/http://www.scotland.gov.uk/Topics/marine/seamanagement/marineact 
for grey seal bunting since 1998. No bunting licences have been issued for Baltic ringed seals since 1988. Since this time 5 - 7 ringed seals have been caught each year for research purposes, mainly to monitor the population's health status.

A bunting licence is required for seal hunting (section 10(2) of the Hunting Act). Each year the Ministry of Agriculture and Forestry determines the maximum quota of animals to be bunted each season in each game management district (1 August-31 July), and lays down rules and guidelines for hunting. The game management districts grant hunting licences to bunters regionally, based on the quotas set by the Ministry. A hunting licence can be granted only if the population of a game species is viable in the region and as long as bunting does not impair the maintenance of the species at a favourable conservation status. There may be fewer licences granted than all those applied for. These situations may occur if it is necessary for the regional management of the population, or for a balanced and practical organisation of hunting activities. One aim of seal hunting is to keep the damage caused by seals to the fishing industry to a minimum. When granting a bunting licence for seals, the regional authority must consider the distribution of damages in their area (section 2 of the Hunting Decree). A licence holder must notify the game management association of the bag obtained (section 9 of the Hunting Decree).

The seal hunt requires a grooved bullet with a weight of at least 3.2 grams and the scoring energy when measured 100 metres from the muzzle must be at least 800 joules. A full jacket bullet may also be used for shooting seals (section 16 of the Hunting Decree). Use of a shotgun loaded with pellets is not permitted, though a bullet prepared for a shotgun may be used (section 18 of the Hunting Decree). A trap for the capture of live animals or other similar hunting device may be used in the capture of Baltic ringed seal and grey seal (section 11 of the Hunting Decree). In Finland hunting rights are linked to the ownership of land and water areas. Persons residing permanently in Finland who have paid a game management fee and hold a bunting licence have the right to hunt in public marine areas, and on islands and islets in areas belonging to the State whose possession has not been transferred to any other (and in the Exclusive Economic Zone of Finland) (section 7 of the Hunting Act). The police and game wardens referred to in section 63(4) of the Hunting Act are responsible for supervising compliance with this Act within their respective jurisdictions. The Finnish Border Guards and customs authorities conduct monitoring operations on the country's border and in areas of land and sea in Finnish territorial waters and in the Exclusive Economic Zone of Finland (section 88 of the Hunting Act).

According to section 35 of the Hunting Act, the chief officer of the Police District may in individual cases grant permission to transport an unloaded bunting weapon in a case on a motor sledge on ice at a certain time using a route notified in advance.

A grey or Baltic ringed seal found in fishing gear belongs to the owner of the gear (section 83 of the Hunting Act).

In special cases an animal such as a sick or injured grey or Baltic ringed seal can be killed pursuant to section 25 of the Police Act (439/1995) or section 14 of the Animal Protection Act (247/1996)"

Compensation for damage to fishing gear can be claimed under provisions of the Fisheries Act and under Section 87 of the Hunting Act and assistance can be provided for the purchase of seal proof fishing gear. EU and related food inspection regulations govern the use of seal meat when it is sold as food but an exception is made when the hunting is for one's own use. The increasing use of seals as a natural resource is considered to be important in maintaining local coastal traditions. However, increasing seal populations, particularly of grey seals, are resulting in increased damage to fishing gear and catches and increasing demands for control of seals. Hardening attitudes toward seals have in part stimulated the requirement for "comprehensive and harmonised policy for the systematic management of seal populations" (Anonymous 2007a).

The primary objectives of the management plan are:

1) To maintain Finnish seal populations viable

2) To manage seal populations so that they can be used in a diverse and sustainable way

3) To minimise damage to the fishing industry as a result of viable seal populations

4) To increase awareness among the general public of the seal and its value as an important natural resource

5) To develop tools of improving coexistence between man and seal and to ease conflicting views among the various stakeholders.

Specific separate objectives are given for grey and ringed seals. Those for the grey seal are:

Objectives:

The objective is to enable the coexistence between seal and man in such a way that the grey seal is seen as a valuable natural resource that can be utilised in a diverse and sustainable way.

The management of the grey seal population will take account of the regional and local fishing and fish farming industry, through closer cooperation and by exchanging information between the various stakeholders to prevent and compensate for damage caused by seals. 
And for the ringed seal:

Objectives:

The preconditions for a viable ringed seal population are ensured in all management areas.

The development of the ringed seal population and the occurrence of uterine occlusion will be monitored in each management area.

The status of the ringed seal population and its current reproductive rates will be examined, especially in the southern management areas.

The management of the ringed seal population will take account of the regional and local fishing and fish farming industry, through closer cooperation and by exchanging information between the various stakeholders to prevent and compensate for damage caused by seals.

The elimination of damage causing individual seals will be allowed so as to prevent damages. [to fishing gear]

Finnish coastal areas and waters are divided into six management areas with further management objectives for particular areas. The conservation of seals is dealt with in an additional set of objectives.

Section 13 of the management plan discusses with the utilization of seals in terms of eco-tourism on the one hand, and consumptive use of the resource on the other, with the following measures to be taken:

Measure:

The utilisation of seals as a natural resource will be supported and developed, however without creating a conflict with reaching the favourable development of the populations.

Possibilities to use seal products for human consumption will be explored. The frequency of trichinae in Baltic seal populations will be examined.

\subsection{Seals and fisheries conflicts}

There is a long history of conflict between seals and fisheries in European waters (e.g. in the Netherlands, De Vooys et al. 2012). There was heavy exploitation of seals in some parts, such as in the Baltic Sea in the early 1900s (Anonymous 2007b), and a tradition of bounty hunting that extended until as late as the 1970s in some areas (De Vooys et al. 2012). With the ongoing recovery of seal populations in EU waters, seal-fisheries conflicts are clearly increasing (Butler 2011, Butler et al. 2011). Research into ways of mitigating conflict through the development of seal proof fishing gear, repellent devices, and identifying and killing habitual trap raiding seals is underway (e.g. Königson and Lunneryd 2012)

In some EU countries specific provisions are in place to compensate fishers for damage to gear and their catches caused by seals. The Swedish management plan for grey seals (Anonymous 2001b) provides details of the level of subsidy and expected costs of implementing the management plan, and meeting subsidies and compensation for seal damage.

Compensation for seal damage paid in 1995 was 6.4 million SEK ( USD 890,000), and by 2001 this had risen to 18.3 million SEK ( USD 2.6 million) (Anonymous 2001b). The cost of fishing gear damaged during 1997 was 22 million SEK ( USD 3.1 million).

In Finland, damage by seals to the professional fishing industry during the period from 1997-1999 was estimated at $€ 1.68$ million. Eleven years later, by which time the grey seal population had doubled, compensation to professional fishers for damage caused by seals had risen to $€ 3.7$ million. However, the actual claims made amounted to $€ 7.47$ million (Anonymous 2007b).

\subsection{Economics of seal harvesting and livelihood issues}

As a result of legal and policy frameworks, no commercial seal hunts take place within the EU. Limited hunting of seals is allowed in some countries (e.g. Finland and Sweden). In Finland, individual hunters may sell seal products, such as meat. It is not clear what happens to the pelts of seals hunted, killed in protection of fishing gear, or killed as bycatch. The following quotation from the World Trade Organisation ruling on the EU seal products trade ban (WTO May 2014) indicates where exceptions to 
the ban may be permitted, and presumably these also apply to seal products generated from within the EU.

"The EU Seal Regime probibits the placing of seal products on the EU market unless they qualify under certain exceptions, consisting of the following: (i) seal products obtained from seals hunted by Inuit or other indigenous communities (IC exception); (ii) seal products obtained from seals bunted for purposes of marine resource management (MRM exception); and (iii) seal products brought by travellers into the European Union in limited circumstances (Travellers exception).

13 The EU Seal Regime lays down specific requirements in respect of each of these exceptions."

The marine management exception raises an interesting question about whether or not commercial seal harvests such as those conducted by Canada, Norway and Namibia would qualify as marine resource management, or whether the exception applies only to seals harvested within the EU?

\subsection{Seal management, research and conservation costs}

In Sweden the estimated budget for implementing monitoring and related requirements for the five-year management plan (for 2001 to 2005) was 28 million SEK ( USD 2.7 million), excluding costs of compensation (Anonymous 2001b, Table 8). 


\section{UNITED STATES OF AMERICA}

Four of the seal species being considered in this report occur in American waters. Northern fur seals occur in the North Pacific Ocean from California to Alaska, ringed seals occur in Alaskan waters, harbour seals occur on the east and west coasts of North America (north of about $30^{\circ}$ ), and grey seals occur off the New England coast. Harbour seals along the Pacific coast (Phoca vitulina richardii) extend from California northwards to the Aleutian Archipelago and Bristol Bay. On the east coast, P. v. concolor occurs from North Carolina to Maine. Ringed seals occur in the Bering, Chukchi and Beaufort Seas off the coast of Alaska. Two species, harp and hooded seals occasionally occur as vagrants off the New England coast.

The USA Marine Mammal Protection Act ${ }^{19}$ (MMPA) of 1972 prohibits commercial harvesting of seals, as well as the import of seal products into the country. Subsistence harvesting of seals is permitted by the MMPA and implemented through co-management agreements with native peoples in Alaska (Marine Mammal Commission 2008).

\subsection{Seal population numbers and harvests}

Northern fur seal numbers have been declining for several years along with several other pinniped species in the North Pacific, probably due to a climate induced regime shift (e.g. Small et al 2008, Kovacs and Lydersen 2012, Kovacs et al. 2012, Maschner et al. 2014). On the basis of pup counts on Sea Lion Rock in 2008, St. Paul and St. George Islands in 2010 and Bogoslof Island in 2011 the most recent estimate for the fur seal stock in the Eastern Pacific is 639,545 (Allen and Angliss 2014). The species is classified as "depleted" under the MMPA. The Bogoslof Island population, which showed rapid growth from 1978 when northern fur seals first colonised the island, appears to have reached carrying capacity (Kuhn et al. 2014).

The ringed seal population size in waters off Alaska is unknown and there is no reliable information on trends (Allen and Angliss 2014). The annual subsistence harvest is thought to be $\sim 9,500$. The species has recently been classified as endangered under the Endangered Species Act and as "strategic stock" under the MMPA (Federal Register 2014), due to expected habitat losses in the coming decades due to global warming.

Table 7.1. Population size and mortality for seal stocks in United States waters (Source: compiled from Allen \& Angliss 2013, 2014, Carretta et al. 2013, Waring et al. (2013)

\begin{tabular}{|c|r|r|r|}
\hline Stock & $\begin{array}{r}\text { Population } \\
\text { size }\end{array}$ & $\begin{array}{r}\text { Human caused } \\
\text { mortality (seals/yr) }\end{array}$ & $\begin{array}{r}\text { Subsistence } \\
\text { harvest (seals/yr) }\end{array}$ \\
\hline East Coast - Harbour seals & $99,340^{\mathrm{a}}$ & 332 & None \\
\hline - Gray seals & $?$ & 928 & None \\
\hline West Coast - Harbour seals & 60,000 & 40 & None \\
\hline - Northern fur & 10,000 & $?$ & None \\
\hline Alaska - Northern fur & 639,545 & 4 & 496 \\
\hline - Harbour & 152,602 & 24 & 1,737 \\
\hline - Ringed & $?$ & $?$ & 2,000 to 10,000 \\
\hline
\end{tabular}

a/ 2001 estimate, there are insufficient current data to provide estimates of harbour and grey seal populations on the East Coast (Waring et al. 2013)

Harbour seals on the west coast have experienced marked declines in the Gulf of Alaska and Prince William Sound, which in part may have been associated with the Exxon Valdez disaster (Allen and

19/ Available at: http://www.nmfs.noaa.gov/pr/laws/mmpa/ 
Angliss 2013). The harbour seal population on the east coast has been growing at about $6 \%$ per annum since 1981 (Waring et al. 2014). The harbour seal population in Alaskan waters is estimated to number 152,602 seals based on aerial surveys carried out between 1998 and 2007 (Allen and Angliss 2014). The current trend in the population is not known. Subsistence harvesting of harbour seals takes place across their range in Alaska and the annual harvest is estimated to be 1,737 seals.

Grey seals have, since 1990, re-established breeding colonies in New England where the population is apparently growing, though estimates of population size are not presently available (Waring et al. 2013).

Available estimates of population sizes for the east and west coasts of the USA, annual human caused mortalities (primarily from bycatch in fisheries), and subsistence harvest levels have been extracted (Table 7.1) from the National Marine and Fisheries Service (NMFS) Stock Assessment Reports.

\subsection{Government policy and management of seals}

The northern fur seal was in the past subjected to periods of extreme overexploitation by American and Russian sealers, followed by later attempts to regulate catches and conserve the species. The first international initiative to control the exploitation of seals was embodied in the Fur Seal Treaty of 1911 (or more fully "Convention between the United States, Great Britain, Russia and Japan for the Preservation and Protection of Fur Seals"). The treaty prohibited the taking of pelagic seals within the species range, and no vessels connected with pelagic sealing were to be allowed to use any ports of the contracting countries. Seals could only be harvested on land under permit, and skins derived from permissible harvests were to be officially marked. Indigenous peoples (e.g. living on the Pribilof Islands, Fig. 7.1) were exempted from the provisions of the convention. The provisions of the treaty allowed the northern fur seal populations to recover.

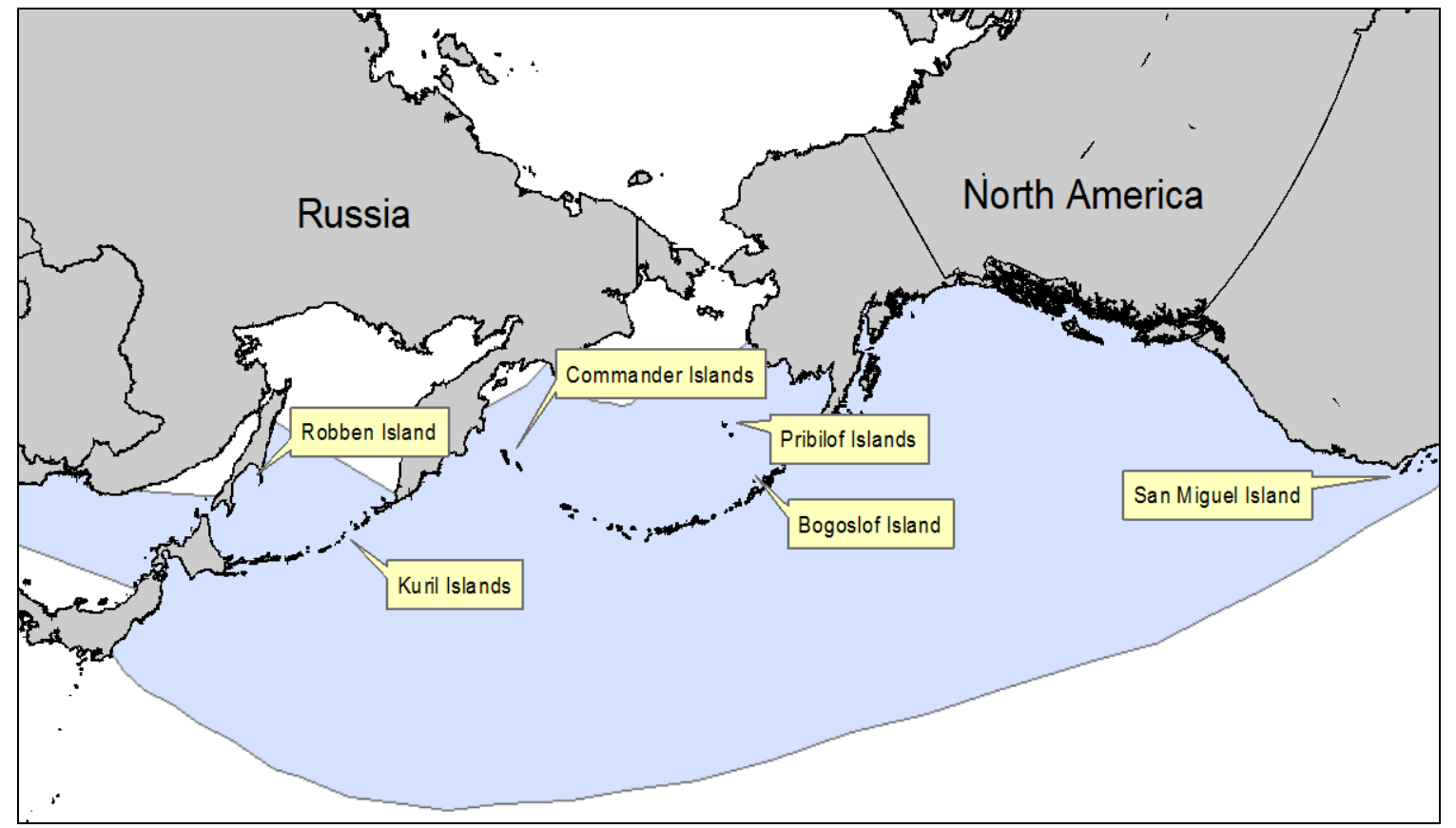

Figure. 7.1 Northern fur seal breeding colonies and the extent of their winter range. (Source: NMFS 2007)

\subsubsection{Legislation governing marine resources and seals}

The Fur Seal Treaty of 1911 was followed by the Interim Convention on the Conservation of North Pacific Fur Seals, which was signed in Washington in February 1957, and then extended in 1963, 1969, 
1976, and 1980. Under the terms of the 1980 extension, the Convention expired in October 1984, after which time the United States declined to sign an extension (NMFS 2007).

The Fur Seal Act of $1966^{20}$ "probibited, except under specified conditions, the taking, including transportation, importing or possession, of fur seals and sea otters. Exceptions are authorized for Indians, Aleuts, and Eskimos who dwell on the coasts of the North Pacific Ocean, who are permitted to take fur seals and dispose of their skins. The statute also authorized the Secretary of Interior to conduct scientific research on the fur seal resources of the North Pacific Ocean" (Citation: 16 USC 1151 - 1187).

The Marine Mammal Protection Act of 1972 (MMPA) forms the primary legislation governing the conservation and management of seals in US waters. The intent of the MMPA is enunciated in the opening "Findings and Declaration of Policy".

\section{"Findings and Declaration of Policy \\ 16 U.S.C. 1361}

Sec. 2. The Congress finds that-

(1) certain species and population stocks of marine mammals are, or may be, in danger of extinction or depletion as a result of man's activities;

(2) such species and population stocks should not be permitted to diminish beyond the point at which they cease to be a significant functioning element in the ecosystem of which they are a part, and, consistent with this major objective, they should not be permitted to diminish below their optimum sustainable population. Further measures should be immediately taken to replenish any species or population stock, which has already diminished below that population. In particular, efforts should be made to protect essential habitats, including the rookeries, mating grounds, and areas of similar significance for each species of marine mammal from the adverse effect of man's actions;

(3) there is inadequate knowledge of the ecology and population dynamics of such marine mammals and of the factors which bear upon their ability to reproduce themselves successfully;

(4) negotiations should be undertaken immediately to encourage the development of international arrangements for research on, and conservation of, all marine mammals;

(5) marine mammals and marine mammal products either-

(A) move in interstate commerce, or

(B) affect the balance of marine ecosystems in a manner which is important to other animals and animal products which move in interstate commerce, and that the protection and conservation of marine mammals and their habitats is therefore necessary to insure the continuing availability of those products which move in interstate commerce; and

(6) marine mammals have proven themselves to be resources of great international significance, esthetic and recreational as well as economic, and it is the sense of the Congress that they should be protected and encouraged to develop to the greatest extent feasible commensurate with sound policies of resource management and that the primary objective of their management should be to maintain the bealth and stability of the marine ecosystem. Whenever consistent with this primary objective, it should be the goal to obtain an optimum sustainable population keeping in mind the carrying capacity of the habitat."

Exemptions to the moratorium are provided for in Sections 101 (a) and (b) of the Act Sec. 101.

(a) Imposition; exceptions There shall be a moratorium on the taking and importation of marine mammals and marine mammal products, commencing on the effective date of this chapter, during which time no permit may be issued for the taking of any marine mammal and no marine mammal or marine mammal product may be imported into the United States except in the following cases:

\section{(b) Exemptions for Alaskan natives}

Except as provided in section 1379 of this title, the provisions of this chapter shall not apply with respect to the taking of any marine mammal by any Indian, Aleut, or Eskimo who resides in Alaska and who dwells on the coast of the North Pacific Ocean or the Arctic Ocean if such taking -

(1) is for subsistence purposes; or

(2) is done for purposes of creating and selling authentic native articles of handi-crafts and clothing: Provided, That only authentic native articles of handicrafts and clothing may be sold in interstate commerce: And provided further, That any edible portion of marine mammals may be sold in native villages and towns in Alaska or for native consumption.

20/ Available at: http://www.animallaw.info/statutes/stus... 


\subsubsection{Management plans}

Following the termination of the Interim Convention on the Conservation of the North Pacific Fur Seal in 1984, the Commonwealth of Independent States and the United States became responsible for the management of the northern fur seal. The eastern North Pacific stock of the northern fur seal was listed as 'depleted' under the U.S. Marine Mammal Protection Act in 1988, when numbers had declined to less than $50 \%$ of the population counts recorded in the 1950s. As a result, the National Marine Fisheries Service (NMFS) published a conservation plan for the population of the Pribilof Islands in 1993. Following the continuing decline of the population, a revised, comprehensive conservation plan was completed in December 2007 (Gelatt and Lowry 2008, NMFS 2007).

The overall goal of the management plan was to restore the Eastern Pacific stock centred on the Pribilof Islands to a stock that is no longer designated as depleted, and for the stock to recover to its optimum sustainable population (OSP) level. The four objectives of the plan are (NMFS 2007): Objective 1. Identify and eliminate or mitigate the cause or causes of human related mortality of the Eastern Pacific stock of
northern fur seals;

Objective 2. Assess and avoid or mitigate adverse effects of human related activities on or near the Pribilof Islands and other habitat essential to the survival and recovery of the Eastern Pacific stock of northern fur seals;

Objective 3. Continue and, as necessary, expand research or management programs to monitor trends and detect natural or buman-related causes of change in the northern fur seal stock and habitats essential to its survival and recovery;

Objective 4. Coordinate and assess the implementation of the conservation plan, based on implementation of conservation actions and completion of high priority studies.

The indigenous communities living on St. George and St Paul Islands are allocated a small annual subsistence catch that is considered not to impact the northern fur seal population. Since 1997, the TAC has been set at 2,000 and 500 for Saint Paul and St. George islands respectively. The annual take has generally been well below these levels and has been declining since 2000. The take for 2013 was 298 seals for St. George and 80 for Saint Paul. The National Oceanic and Atmospheric Administration (NOAA) proposed to extend the current TACs through to 2016 (Federal Register, 2014)

\subsection{Seals and fisheries conflicts}

Under the Marine Mammal Protection Act, the NMFS is mandated to "regularly evaluate interactions between marine mammals and commercial fisheries" for northern fur seals (NMFS 2007). However, as the management plan notes (page 41) "Ecosystem complexity, data and model limitations, and indirect linkages confound the quantification of most interactions between northern fur seals, their prey, and commercial fisheries." Adverse impacts, or perceptions of adverse impacts, of northern fur seals on North Pacific fisheries do not appear to be prevalent at present. However, there is evidence of a significant impact of fisheries on northern fur seal mortality resulting from discarded fishing gear such as nets (Fowler 1982, 1987; Laist 1987, Lee et al. 2014).

As a result of expanding populations of grey and harbour seals on the east coast of the USA, there are increasing concerns about their impact on inshore fisheries as outlined by Fine (2012). As occurred in European waters, both grey and harbour seal populations were depleted during the last century by bounty hunting (e.g. Lelli et al. 2009, DeMaster and Sisson 1992).

Harbour seals in Alaskan waters are divided into eleven stocks that are assessed as separate entities (Allen and Angliss 2013). Assessed mortality due to fisheries is low with an estimated rate of 24 harbour seals being killed per year. However, this figure is derived from 1990-91 data for the Prince William Sound salmon drift gillnet fishery. Statistics of fisheries related mortality for harbour seals from three other fisheries during the period 2007-2010 indicate a minimum annual mortality rate of 1.34 (Allen and Angliss 2013). Information on their impacts on fisheries has not been found. 


\subsection{Economics of seal harvesting and livelihood issues}

As in northern Canada, seals play an important role in the lives of native peoples living in Alaskan coastal areas (e.g. Meek 2009, 2013, Meek et al. 2011, Nutttal et al. 2005).

The US ban on importing seal products will have affected the livelihoods of communities harvesting seals, whether for subsistence or commercial use, in Canada and Greenland. However, these impacts do not appear to have been quantified following the 1972 ban by the USA. 


\section{NAMIBIA}

Two subspecies of Cape fur seal are recognised. One, Arctocephalus pusillus pusillus, occurs in the southern African coastal waters, while the other (A. $p$. doriferus) is limited to south-eastern Australian and Tasmanian coastal waters. In southern Africa the Cape fur seal occurs along the west coast in Namibia and South Africa, and along the south-east coast in South Africa far north as Algoa Bay. There is a newly established colony on Bias dos Tigre ${ }^{21}$ in southern Angola, just north of the Angola/Namibia border (Kirkman 2010).

As with fur seals elsewhere in the southern oceans, over-exploitation of Namibia's Cape fur seals occurred in the late $18^{\text {th }}$ and early $19^{\text {th }}$ centuries, leaving depleted populations in southern African waters. The total population was considered to have been less than 100,000 at the beginning of the $20^{\text {th }}$ century (Shaughnessy and Butterworth 1981). It recovered from 200,000 seals in 1920 to 1.7 million in 1993 (Punt and Butterworth 1995, Cochrane et al. 2004). In Namibia, breeding colonies expanded from 23 in 1973 to 40 in 2009, partly as a result of a reduction in the number of islands being managed for guano harvesting (Kirkman et al. 2013). South Africa stopped commercial sealing in 1990, and the southern Benguela seal population (i.e. in South African waters) appears to have stabilised at about 700,000 seals (Kirkman 2010), while that in the north is expanding (van der Lingen et al. 2006, Walters 2012a). Sealing in Namibia is restricted to three mainland colonies, namely Cape Cross, Wolf Bay and Atlas Bay. Angola was reported to be planning to cull seals on Bias dos Tigres to reduce impacts on coastal fisheries (Kirkman 2010).

\subsection{Seal population numbers and harvests}

The Namibian population is estimated to be about 1.2 million (Walters 2012a) with an annual total allowable catch (TAC) of 85,000 pups and 7,000 adult males from the three mainland-based rookeries. Reported catches have, however, been well below the TAC (Table 2.1). The Namibian population has experienced two major die offs that appear to have been caused by spatial and temporal changes in prey availability and regime shifts in the Benguela current system (van der Lingen et al. 2006). A collapse occurred in 1984 and again 1994-95, when large numbers of seals died of starvation, and the population was reduced by approximately one third. The population has since recovered, and the highest pup count since the last collapse was recorded in 2011 (Walters 2012b).

Table 8.1 Annual Total Allowable Catch (TAC) for Cape fur seal pups and adult males from three rookeries on the Namibia coast. (Sources: Walters 2012b, Annual Reports of the Ministry of Fisheries and Marine Resources - MFMR)

\begin{tabular}{|r|r|r|r|r|r|}
\hline \multirow{2}{*}{ Year } & \multicolumn{2}{|c|}{ TAC } & \multicolumn{2}{|c|}{ Total Catch } & \multirow{2}{*}{ \% of TAC } \\
\cline { 2 - 5 } & Pups & Bulls & Walters & MFMR & \\
\hline 2007 & 80,000 & 6,000 & 34,668 & 34,728 & 40.4 \\
\hline 2008 & 80,000 & 6,000 & 45,677 & 47,603 & 55.4 \\
\hline 2009 & 85,000 & 7,000 & 41,146 & 41,405 & 45.5 \\
\hline 2010 & 85,000 & 7,000 & 45,590 & 47,821 & 52.0 \\
\hline 2011 & 85,000 & 7,000 & 45,883 & & 49.9 \\
\hline
\end{tabular}

21 / The island was formerly a human occupied peninsula that was recently separated from the mainland and abandoned when the pipeline providing a freshwater supply to the settlement from the Kunene River was severed. 


\subsection{Government policy and management of seals}

The Constitution of the Republic of Namibia explicitly includes provisions for the sustainable use of natural resources for the benefit of its people, and this is reflected in Chapter 11, Principles of State Policy. Article 95: Promotion of the Welfare of the People, as follows:

"The State shall actively promote and maintain the welfare of the people by adopting, inter alia, policies aimed at the following:

(I) maintenance of ecosystems, essential ecological processes and biological diversity of Namibia and utilization of living natural resources on a sustainable basis for the benefit of all Namibians, both present and future; in particular, the Government shall provide measures against the dumping or recycling of foreign nuclear and toxic waste on Namibian territory."

Before Namibian independence in March of 1990, the Sea Fisheries Act of 1973 governed fisheries per se, while the Sea Birds and Seals Protection Act, 45 of 1973 (both South African legal instruments applying to South West Africa), governed the management of seals and marine birds. The Namibian Sea Fisheries Act of 1992 replaced the 1973 Act, but still explicitly excluded seals. Under this Act, fish were defined as follows:

"fish means every species of sea animal, whether vertebrate or invertebrate, including the spawn or larvae of such sea animals, but excluding any seal or bird;"

Both the 1992 Sea Fisheries Act and the Sea Birds and Seals Act of 1973 were repealed and replaced by the Marine Resources Act 27 of 2000. The Act, however, is silent on the conservation and management of seals, and the only mention of seals is in relation to the repeal of the Sea Birds and Seal Protection Act of 1973. However, regulations under the Marine Resources Act make the following provisions regarding the harvesting of seals (Government Gazette 7 December 2001 No 2657, Section 20, page 14):

\section{"Seals}

20.

(1) Seals must be harvested in the presence of at least one fisheries inspector.

(2) A bolder of a right relating to the harvest of seals must identify a group of pups to be harvested, which must be driven away from the sea and allowed to settle down before clubbing begins, care being taken to facilitate the escape of adult seals.

(3) After the identified pups have settled down, they must be harvested as follows:

(a) a group of pups must be released from the group referred to in subregulation (2) in the direction of the sea;

(b) a clubber must kill a pup by clubbing it on the top of the head with a sealing club, when a group released in terms of paragraph (a) moves past the clubbers;

(c) the inspector overseeing the harvest must be satisfied that a pup, which has been clubbed, is dead;

(d) a sticker must pierce the heart of the pup with a knife, after the pup has been clubbed;

(4) Adult seals selected for harvesting must -

(a) be killed on land by shooting the seal with a rifle in the head so that the bullet immediately kills the seal;

(b) the inspector overseeing the harvest must be satisfied that a seal, which has been shot, is dead."

Namibia's Marine Resources Policy White Paper of August 2004 (Republic of Namibia 2004) has the following references to seals and approaches to managing marine resources:

1. Page 1: "All important commercial species such as hake, monkfish, ...... large pelagics and seals are Total Allowable Catch (TAC) and quota managed fisheries."

2. Page 4: "The harvesting of Cape fur seals off the coast of Namibia can be traced back to the 19th Century when European and American sealers frequented seal colonies. The fur seal population has been assessed through aerial censuses since 1972. The censuses have shown a steady increase of the Namibian pup production of between 4-5\% each year from 1972 up to a peak value in 1993. This was followed by a mass mortality event in 1994 and drop in pup production in the following years. The December 1997 aerial census indicated pup production of the 1998 
cohort recovered to about $85 \%$ of the pre-1994 level. The main colonies are harvested based individual quotas given as part of the TAC."

3. Page 7: “2. MARINE RESOURCE MANAGEMENT

\subsection{APPROACH TO RESOURCE MANAGEMENT}

The Government's primary task at Independence has been to rebuild Namibia's overexploited and depleted resources to maximum sustainable levels, maintain the other stocks in a healthy condition and explore the possibilities of developing new fisheries. To this end, the Government ha adopted an overall policy of developing a national fisheries sector. For this purpose the Government reduced catches over a period of time. Controls in the form of annual TACs, by-catch restrictions and introducing closed season and areas, amongst others are being enforced.

In the process of setting TACs and allocating individual quotas, various stock assessment models are being tested with a view to refine them for future use. In addition, management plans for all the stocks are being developed which include biological reference points. TACs are set on biologically sustainable principles. However, the way the TACs are managed and allocations are made to right holders in different industries (for example the splitting of the horse mackerel TAC between the mid-water trawlers and the purse-seine vessels) is done to ensure sustainable and diverse utilisation of the resources while enhancing fishery specific sectors and the national economy."

4. Page 9: "2.10 CAPE FUR SEAL

"... TACs were set from the mid-1970s. Various input data sets are generated, for example a pup count is done by photographing the colonies from the air, estimating pup mortality and monitoring pup growth. These data sets are fed into a model to produce a recommended harvest level. A Seal Management Plan with a life span of three years was introduced in 1998.

A closed season is in effect to reduce disturbance of the Cape fur seal colonies. Harvesting of bulls and pups are allocated but no female quotas are given."

The Namibian seal harvest was legally challenged in 2012. Because this was a challenge to commercial sealing at a national level that was adjudicated by the Ombudsman of Namibia it is instructive to quote extensively from the Ombudsman's findings.

The Namibian Ombudsman examined the following complaints opposing the annual hunt of Cape fur seals on the coast of Namibia (Walters 2012a and 2012b):

- it is contrary to Namibian law and Namibia's obligations under international law;

- Namibia's law regulates it inadequately;

- it violates the principle of sustainable utilization contained in the Namibian Constitution and the MRA;

- the MRA and the Regulations are contradictory and together inadequately protect seals;

- the Regulations are impossible to implement;

- it violates the Animal Protection Act, no 71 of 1962 (APA);

- it violates the "right" of seals and the brutal killing of seals negatively affect sealers; and

- the Minister of Fisheries and Marine Resources, in authorising seal harvest in areas not governed by the MRA, exceeds the jurisdiction of his powers (jurisdictional issues).

The findings and recommendations of the Ombudsman (Walters 2012a) were as follows:

\section{FINDINGS}

Having considered all the submissions and information received from various concerned organisations as well as my own research, site visits and interviews, I find that: 
- the exploitation of Cape fur seals along the Southern African coast represent [s] one of the oldest commercial fisheries in the region and dates back more than three centuries;

- despite the early years of uncontrolled and indiscriminate exploitation, seals are still with us and will be with us for a long time to come if we are careful;

- seal harvesting at Cape Cross started in 1884 when it was the monopoly of the Deutsche Kolonial-Gesellschaft;

- the legal framework which the Namibian government put in place for the sustainable utilization of living natural resources is well anchored and its accession to a number of international instruments, demonstrates its commitment to the management of its marine resources;

- harvesting of seals are lawful; the Minister of Fisheries and Marine Resources does not exceed his jurisdiction and bis power in respect of the management and utilization of seals in Namibia, extends over Namibian waters and Namibian land, including Cape Cross and Wolf and Atlas Bays;

- seals, when harvested, are not under the control of the sealers because they are unrestrained, always in motion and run towards, past and away from the clubbers;

- seals, as wild animals, do not fall within the ambit of the definition of animals in the Animal Protection Act $(A P A)$; the sealers, and by extension "the authorities who permit the cruel treatment of pups", can thus not be in breach of any of the provisions of the $A P A$; the APA does not confer rights on seals, but does protect them from cruelty;

- $\quad$ pups are not allowed to settle down as required by the Regulations; as wild animals they can only settle down when confined;

- however gruesome it may sound, the stunning and sticking method used for killing pups is the most practical and the only one applicable to the harvest in Namibia;

- a club strike on the head of a pup (although it may appear brutal) is humane if it achieves rapid, irreversible loss of consciousness and leading to death;

- the Namibian harvest does not always comply with the "four steps" method of effective hitting/shooting, effective monitoring, effective bleeding out and effective implementation;

- the Regulations do not place an upper limit on the size of the group of pups to be beld before clubbing begins and do not specify a time limit between stunning and sticking;

- the Regulations do not require that male seals should be bled-out after shooting;

- Regulation 18(1) is in conflict with section 32(1) of the MRA; such inconsistency is undesirable and creates uncertainty;

- the Ministry of Environment and Tourism issues CITES export permits and not the Ministry of Fisheries and Marine Resources;

- the Regulations do not require that sealers should be trained and competent in the procedures they use, including killing methods, monitoring death, etc.;

- the state veterinarian inspects seal products before they are exported;

- the Ministry of Fisheries and Marine Resources is very reluctant to part with information (which is in any event in the public interest), even to the Ombudsman."

\section{“RECOMMENDATIONS}

From the facts placed before me I do not have adequate and sufficient grounds in law and fact to recommend to the Namibian government to stop the annual seal harvest; however, I do believe that the following recommendations may address the concerns relating to seal harvesting in Namibia:

- Regulation 18(1) of the MRA Regulations should be amended to bring it in line with section 32(1) of the MRA.

- Regulation 20 should be amended by adding the following requirements:

- After being killed by shooting, adult seals should be bled out; 
- seals (both pups and adults) should be bled out as soon as possible, preferably immediately after they have been successfully stunned or shot, and they should be checked to ensure that they are irreversibly unconscious or dead;

- compelling rights holders to erect temporary enclosures where pups, not exceeding 100 at a time, can be confined to settle down before they are released and clubbed;

- rights holders should ensure that each harvest complies with the "four steps" method of effective bitting/shooting, effective monitoring, effective bleeding out and effective implementation;

- $\quad$ sealers should be trained and competent in the procedures they use, including killing methods, monitoring death, unconsciousness and rapid bleeding.

- The Minister should consider independent monitoring of harvests (without commercial/ industry or NGO links) to provide certain critical information on seal killing and stunning from a welfare prospective.

- It is in the public interest that data (information) regarding the total number of the seal population, the size of the quotas, the actual number of pups and male seals harvested, etc be published annually.

- If the Minister did not publish the texts of all conservation and management measures adopted under any international agreement to which Namibia is party, in the Gazette, it should be done without delay."

It is presently not clear whether the Ombudsman's findings have been legally challenged, or to what extent his recommendations have been adopted and implemented by the Namibian Government. On the basis of the above findings the conduct of the Namibian seal hunt does not meet the standards required in Canada and Norway.

De Klerk (2013), in a dissertation submitted in partial fulfilment for a Bachelor of Laws degree at the University of Namibia, conducted a critical analysis of seal harvesting in Namibia and of the Ombudsman's report (Walter 2012a, 2012b). The periodic population estimates of Cape fur seals in several colonies on the Namibian coast and islands (e.g. Walters 2012b) do not support the conclusion by de Klerk (2013), and others, that the TAC of seals is causing the decline and likely extinction of seals in Namibia. However, the recommendations by the Ombudsman, and by de Klerk (2013), for improving both the legal regulations and practice of the seal harvest, do not appear to have been adopted by the Government or the sealers as yet (de Klerk 2013).

\subsection{Seals and fisheries conflicts}

The minister responsible for fisheries has been reported as stating that the annual seal cull is necessary to reduce seal impacts on Namibian fisheries, but this sentiment does not appear to be reflected in any official policy documents. Wickens (1995) provided a comprehensive review of seal- fisheries interactions. The costs of seal impacts on various types of fishery in South Africa were found to amount to between 2.5 to 5 million Rand per year, or 0.3 to $0.7 \%$ of the value of the fishing industry. The effects of different fisheries on seals were also evaluated, with an estimate given of up to 3,327 seals being killed per year in bycatch. Further deliberate killing of seals during fishing operations was estimated to be up to 1,400 seals per year. Current estimates of bycatch and deliberate killing of seals during fishing operations in South Africa and Namibia have not been found.

The question of culling seals to reduce impacts on fish stocks in the Benguela upwelling system along the west coast of southern Africa has been examined within the framework of "Minimum realistic models" (e.g. Punt and Butterworth 1995). The results suggest that culling may result in counter-productive effects through the release of fish predators. Ecosystems analysis of the Benguela system and ecosystems management approaches (e.g. Cochrane et al. 2004, Kirkman 2010, van der Lingen et al. 2006, Travis et al. 2014) also caution against culling seals to improve returns to fisheries. 


\subsection{Economics of seal harvesting and livelihood issues in Namibia}

Campbell et al. (2011) ${ }^{22}$ examined the economics of the seal harvesting and seal watching industries in Namibia that rely on Cape fur seals on the Namibian coast. They estimated the landed catch value of seal harvesting from 58,000 pups and 5,500 adult seals ${ }^{23}$ in 2008 to be US $\$ 513,000$. Seal watching, based on the 2008 figures, was estimated to have generated US $\$ 2$ million in direct tourism revenues. The authors noted that the seal harvesting industry was probably approaching a limit in its development, while the seal watching industry had the capacity for considerable growth with an estimated direct value of US $\$ 3.4$ million by 2016. Campbell et al. (2011) argued that seal hunting could prejudice a larger and more sustainable seal watching industry by affecting the willingness of tourists to visit the Cape Cross rookery, but they did not provide evidence in support of this conclusion.

De Klerk (2013) examined and commented on the economics of the Namibia seal harvest, but her data were drawn largely from Campbell et al. (2011).

22/ This work was published under the banner of "Economists without Borders" and was commisioned by Humane Society International, World Society for the Protection of Animals, Bont voor Dieren (NL) and Respect for Animals (UK).

23/ These figures differed from the officially reported harvest for 2008 but do not alter the thrust of their argument. 


\section{ANTARCTICA}

Six seal species occur in Antarctic waters, i.e. south of $60^{\circ}$ latitude. These are Weddell seals (Leptonychotes weddelli), crabeater seals (Lobondon carcinophagus), leopard seals (Hydrurga leptonyx), Ross seals (Ommatophoca rossi), Antarctic fur seals (Arctocephalus gazella), and southern elephant seals (Mirounga angustirostris). Fur seals and elephant seals were heavily exploited during the early $19^{\text {th }}$ century in the southern oceans with the result that, by about 1830, species of commercial value were to all intents and purposes economically extinct. By the early $20^{\text {th }}$ century, commercial sealing in the southern oceans had virtually ended, and had been replaced by whaling (Cioppa 1995). A Norwegian vessel made the last commercial sealing expedition to Antarctic waters in 1964, when 864 seals were harvested (Bonner 1982). The expedition was not economically viable and has not been repeated since.

\subsection{Seal population numbers}

The most numerous pinniped in Antarctic waters is the crabeater seal. Estimates of crabeater seal abundance have varied greatly but an estimate of 7 million seals (Erickson and Hanson 1990) is frequently quoted. Populations of each of the remaining species number several thousand. A review of the data on abundance and trends in ice breeding seals in Antarctica by Southwell et al. (2012) suggest that the circumpolar population of crabeater seals numbered approximately 9.5 million seals, based on the 1997-1999 Antarctic Pack-Ice Seals (APIS) program surveys. The APIS survey population estimate for Ross seals was 78,500, for leopard seals 35,500, and Weddell seals 633,000.

\subsection{Policy and management of seals}

Governance of the Antarctic is complex and continually evolving (Cioppa 1995, Dodds and Hemmings 2013, Lamers et al. 2014)) within the framework of the Antarctic Treaty System (ATS). Provisions for the conservation of living resources were included at the outset of the Antarctic Treaty of 1961, in Section IX (1,0), which refers to the "preservation and conservation of living resources in Antarctica". Measures for the conservation of the fauna and flora of Antarctica were adopted at the Third Consultative Meeting in Brussels in 1964. These measures prohibited citizens of states that were party to the Treaty from killing, capturing, or molesting any bird or mammal native to Antarctica, unless they have the proper permit, that has been issued by their government, to do so (Cioppa 1995). The Ross and Antarctic fur seals were afforded special protection under the Recommendation. Annual catch limits have been set for crabeater, leopard, and Weddell seals.

Three additional agreements under the ATS have since strengthened the conservation efforts and management of Antarctic seals and all Antarctic living natural resources. These are the:

Convention for the Conservation of Antarctic Seals (1972)

Convention on the Conservation of Antarctic Marine Living Resources (1980)

Protocol on Environmental Protection to the Antarctic Treaty (1992)

\subsubsection{Convention for the Conservation of Antarctic seals - 1972 24}

For seals, the primacy of the 1972 convention is upheld in both the 1980 convention and the 1992 protocol.

24/Available at: http://www.antarctica.ac.uk/about_antarctica/geopolitical/treaty/convention.php 
Article I of the 1972 Convention for the Conservation of Antarctic Seals (1972) defines the geographical scope and the species involved, i.e. the six species occurring in Antarctic waters. Article 2, Implementation, specifies, in broad terms, the roles of parties to the convention as follows:

1. 1. The Contracting Parties agree that the species of seals enumerated in Article 1 shall not be killed or captured within the Convention area by their nationals or vessels under their respective flags except in accordance with the provisions of this Convention.

2. 2. Each Contracting Party shall adopt for its nationals and for vessels under its flag such laws, regulations and other measures, including a permit system as appropriate, as may be necessary to implement this Convention.

Article 3 provides for the conservation and management measures that may be adopted by Parties to the Convention that are more fully elaborated in annexes.

1. This Convention includes an Annex specifying measures which the Contracting Parties hereby adopt. Contracting Parties may from time to time in the future adopt other measures with respect to the conservation, scientific study and rational and bumane use of seal resources, prescribing inter alia:

1. permissible catch;

2. protected and unprotected species;

3. open and closed seasons;

4. open and closed areas, including the designation of reserves;

5. the designation of special areas where there shall be no disturbance of seals;

6. limits relating to sex, size, or age for each species;

7. restrictions relating to time of day and duration, limitations of effort and methods of sealing;

8. types and specifications of gear and apparatus and appliances which may be used;

9. catch returns and other statistical and biological records;

10. procedures for facilitating the review and assessment of scientific information;

11. other regulatory measures including an effective system of inspection.

2. The measures adopted under paragraph (1) of this Article shall be based upon the best scientific and technical evidence available.

3. The Annex may from time to time be amended in accordance with the procedures provided for in Article 9.

The permissible catch in the first item of the Annex was, for example, elaborated as follows:

The Contracting Parties shall in any one year, which shall run from 1 July to 30 June inclusive, restrict the total number of seals of each species killed or captured to the numbers specified below. These numbers are subject to review in the light of scientific assessments:

1. in the case of Crabeater seals Lobodon carcinophagus, 175,000;

2. in the case of Leopard seals Hydrurga leptonyx, 12,000;

3. in the case of Weddell seals Leptonychotes weddelli, 5,000.

And in the seventh and final item in the Annex sealing methods were outlined as follows:

1. SCAR ${ }^{25}$ is invited to report on methods of sealing and to make recommendations with a view to ensuring that the killing or capturing of seals is quick, painless and efficient. Contracting Parties, as appropriate, shall adopt rules for their nationals and vessels under their respective flags engaged in the killing and capturing of seals, giving due consideration to the views of SCAR.

2. In the light of the available scientific and technical data, Contracting Parties agree to take appropriate steps to ensure that their nationals and vessels under their respective flags refrain from killing or capturing seals in the water, except in limited quantities to provide for scientific research in conformity with the objectives and principles of this Convention. Such research shall include studies as to the effectiveness of methods of sealing from the viewpoint of the management and humane and rational utilization of the Antarctic seal resources for conservation purposes. The undertaking and the results of any such scientific programme shall be communicated to SCAR and the Depositary, which shall transmit them to the Contracting Parties.

25/ Scientific Committee on Antarctic Research of the International Council of Scientific Unions 


\subsubsection{Convention on the Conservation of Antarctic Marine Living Resources (1980) ${ }^{26}$}

The convention expands upon earlier conservation measures and the Seal Conservation Convention, and introduces the concept of entire ecosystem conservation as reflected in the preamble (See Annex 3) of which the final point is:

Convinced that the development of a comprehensive regime for the protection of the Antarctic environment and dependent and associated ecosystems is in the interest of mankind as a whole;

Desiring to supplement the Antarctic Treaty to this end;

Have agreed as follows: .......

Article I extends the area of concern to include the Antarctic Convergence Zone. Article II (2) states that "For the purposes of this Convention, the term 'conservation' includes rational use." Article II (3) includes explicit harvesting principles that deal with sustainable harvests, maintaining ecological relationships between harvested and dependent related populations, restoring depleted populations and minimising risks of irreversible marine ecosystem changes (see Annex 3 for text).

Article VI makes provision for the precedence of previous conventions as follows:

Nothing in this Convention shall derogate from the rights and obligations of Contracting Parties under the International Convention for the Regulation of Whaling and the Convention for the Conservation of Antarctic Seals.

\subsubsection{Protocol on Environmental Protection to the Antarctic Treaty (1992)}

The preamble emphasises the importance of enhancing protection of the Antarctic environment and associated ecosystems and that the development of a "comprehensive regime for the protection of the Antarctic and dependent and associated ecosystems is in the interest of mankind as a whole." The protocol seeks to supplement the Antarctic Treaty and Article 2, Objective and Designation, commits parties to the Treaty to "the comprehensive protection of the Antarctic environment and dependent and associated ecosystems and hereby designate Antarctica as a natural reserve, devoted to peace and science." (See Annex 3 for further details).

Specific management plans for any of the seal species do not appear to have been developed.

\subsection{Fisheries conflicts}

Wickens (1995), in her comprehensive review of fishery-seal conflicts, does not provide any records of seals being involved in fisheries conflicts in the Antarctic. However, off the southern coast of Chile they may occasionally be killed and used as bait in crab fisheries.

\subsection{Economics of seal harvesting and livelihood issues}

No commercial harvesting has occurred recently or is occurring at present, and because there are no resident communities within Antarctica no livelihood issues arise.

26/ Available at: http://www.antarctica.ac.uk/about_antarctica/geopolitical/treaty/convention.php 


\section{DISCUSSION \& CONCLUSIONS}

\subsection{Introduction}

The terms of reference for this study required a case study approach with a focus on policy and management of seals in eight countries, and on abundant and/or increasing populations of seven species of seals. An additional species, the ringed seal, was added because of its importance to subsistence harvesting of seals in many areas. The countries included in this review are those that have territories within or adjacent to the Arctic Circle; namely, Canada, Greenland, Norway, Russia, the USA (Alaska), the European Union countries (with two that extend into the Arctic circle), and in addition, Namibia and Antarctica in the southern hemisphere. Antarctica is an outlier in that several countries under the umbrella of the Antarctic Treaty System manage it; there are no resident human communities, and seals are not hunted other than for research purposes and occasionally for food.

Canada, Greenland, Russia and the USA all include first nations and indigenous communities that have longstanding traditions relating to the hunting of seals, which form an important component of their livelihoods. Namibia, although a developing nation, does not have a traditional subsistence seal harvest, but it does harvest Cape fur seals commercially each year. Canada and Norway also harvest seals commercially, and Russia did so until as recently as 2008. The European Union, with its many nation states, does not allow commercial seal harvests, but in some countries seals are hunted for food or sport, and they are culled (both legally and illegally) to protect fisheries.

Commercial harvesting of seals has long been a controversial issue. Animal welfare and animal rights campaigns in developed countries have resulted in bans on importing seal products, notably to the USA, EU and Russia. The bans have impacted negatively not only on the commercial seal fur trade, but also on the livelihoods of indigenous peoples and their rights to realise the full benefits of the seals they harvest. Expanding seal populations and their perceived impacts on fisheries are also a controversial and largely unresolved issue.

Across the spectrum of human-seal interactions, a multitude of ecological, economic, social and governance issues arise. At the root of many of the more controversial issues relating to the conservation and management of seals are deeply rooted beliefs and largely irresolvable ethical divisions between different countries and components of society. Though analysis of these issues is important, it is beyond the scope of this report.

The main features that emerge from the country case studies and the investigation of the eight species of seals are summarised in the following sections and tables.

\subsection{Legal and policy frameworks}

Because several levels of governance apply to the conservation and management of seals, there are overlapping jurisdictions that make it difficult to unravel precisely how these various legal and policy frameworks play out in terms of the actual practical management of seals on the ground. In practice, national legislation and policy should not trump the provisions of agreed international treaties and conventions, but the European Union and the United States of America have both transgressed this principle in relation to seals and seal products. It should be noted, however, that there are no provisions in the relevant international treaties to prevent nations from implementing stricter measures in relation to conservation and trade. The EU ban on the import of seal products on moral grounds was upheld by the World Trade organisation. The ruling sets a new, and potentially important, precedent in relation to sustainable use and international trade in living natural resources. 


\subsubsection{International Conventions}

Two global international treaties and conventions apply to the conservation and management of seals; the Convention on Biodiversity and CITES, both of which provide support for the sustainable use of living natural resources, and for their protection when needed. None of the species discussed in this report are listed on CITES Appendices as requiring controls in terms of international trade. Two species, northern fur and hooded seals, are listed as 'Vulnerable' in the IUCN Red List, while the remaining six species are listed as 'Least Concern'.

Table 10.1 Summary of the main features of the legislative, regulatory and management approaches relating to seals in the countries included in this report.

\begin{tabular}{|c|c|c|c|c|c|}
\hline Country/Region & $\begin{array}{l}\text { Legal provision for } \\
\text { sustainable use of } \\
\text { seals }\end{array}$ & $\begin{array}{l}\text { Regulations for } \\
\text { humane seal } \\
\text { harvesting }\end{array}$ & $\begin{array}{l}\text { Management plans } \\
\text { for seals developed } \\
\text { and used }\end{array}$ & $\begin{array}{l}\text { Precautionary / } \\
\text { adaptive } \\
\text { approach } \\
\text { adopted }\end{array}$ & $\begin{array}{l}\text { Ecosystem } \\
\text { approach being } \\
\text { used }\end{array}$ \\
\hline North Atlantic & $\begin{array}{l}\text { ICES } \\
\text { NAMMCO }\end{array}$ & $?$ & $\begin{array}{l}\text { ICES } \\
?\end{array}$ & $\begin{array}{l}\text { ICES advice } \\
?\end{array}$ & $?$ \\
\hline Baltic Sea & Helsinki Convention & $?$ & HELCOM advice & HELCOM advice & $?$ \\
\hline Canada & $\begin{array}{l}\text { Oceans Act, Species } \\
\text { and Risk Act, } \\
\text { Fisheries Act }\end{array}$ & $\begin{array}{l}\text { Yes, under Marine } \\
\text { Mammal Regulations } \\
\text { of the Fisheries Act }\end{array}$ & $\begin{array}{l}\text { DFO - 2011-2015 } \\
\text { Fisheries } \\
\text { Management Plan for } \\
\text { Atlantic Seals }\end{array}$ & $\begin{array}{l}\text { Yes, defined in } \\
\text { management plan }\end{array}$ & Not evident? \\
\hline Greenland & $\begin{array}{l}\text { Kingdom of Denmark } \\
\text { Strategy for the Arctic } \\
2011-2020 \text {, } \\
\text { Laws on Hunting and } \\
\text { Nature Protection }\end{array}$ & $?$ & ? & $\begin{array}{l}\text { Yes, but only in } \\
\text { policy statements }\end{array}$ & Not evident? \\
\hline Norway & $\begin{array}{l}\text { Marine Resources Act } \\
\text { covers marine } \\
\text { mammals }\end{array}$ & $\begin{array}{l}\text { Yes, detailed and } \\
\text { specific regulations }\end{array}$ & $\begin{array}{l}\text { Joint Norwegian- } \\
\text { Russian Fisheries } \\
\text { Commission? }\end{array}$ & $\begin{array}{l}\text { Included in } \\
\text { website statements }\end{array}$ & $\begin{array}{l}\text { Included in website } \\
\text { statements }\end{array}$ \\
\hline Russia & $?$ & $?$ & $?$ & ? & ? \\
\hline USA & $\begin{array}{l}\text { Marine Mammal } \\
\text { Protection Act of } 1972\end{array}$ & $\begin{array}{l}\text { Marine Mammal } \\
\text { Protection Act }\end{array}$ & $\begin{array}{l}\text { Yes, for northern fur } \\
\text { seal }\end{array}$ & Yes & Yes? \\
\hline $\mathrm{EU}$ & $\begin{array}{l}\text { Berne and Helsinki } \\
\text { Conventions, European } \\
\text { Habitat Directive, and } \\
\text { national legislation }\end{array}$ & $\begin{array}{l}\text { Yes, e.g. Marine } \\
\text { Scotland Act } 2010 .\end{array}$ & $\begin{array}{l}\text { Some countries, e.g. } \\
\text { Finland - 2007, } \\
\text { Sweden, 2001-2006 } \\
\text { Wadden Sea, } \\
\text { parts of Scotland }\end{array}$ & Baltic Sea? & Yes? \\
\hline Namibia & $\begin{array}{l}\text { Sea Fisheries Act of } \\
2000 \\
\text { Marine Resources } \\
\text { White Paper } 2004\end{array}$ & $\begin{array}{l}\text { Yes but not as fully } \\
\text { defined as those of } \\
\text { Canada and Norway } \\
\text { (see Walters 2012) }\end{array}$ & $?$ & $\begin{array}{l}\text { Included in policy } \\
\text { statements }\end{array}$ & $\begin{array}{l}\text { Included in policy } \\
\text { statements. }\end{array}$ \\
\hline Antarctica & $\begin{array}{l}\text { Convention for the } \\
\text { Conservation of } \\
\text { Antarctic Seals } 1972 \\
\text { Convention of the } \\
\text { Conservation of } \\
\text { Antarctic Marine Living } \\
\text { Resources } 1980 \\
\text { Protocol on } \\
\text { Environment } \\
\text { Protection to the } \\
\text { Antarctic Treaty } 1992\end{array}$ & No & No & Yes & Yes \\
\hline
\end{tabular}

Both the CBD and CITES make explicit provision for the sustainable use of wild species. The CBD Addis Ababa Principles and Guidelines provide explicit guidelines on sustainable use of natural resources. The convention also includes twelve principles for implementing an ecosystem approach to managing natural resources (See Annex 2).

All of the conventions examined make allowance for the harvesting of seals, provided this is carried out on a sustainable basis and does not adversely affect the conservation status of the species involved. 
International commissions such as ICES, HELCOM, and NAMMCO provide advice and guidance on management and TACs.

\subsubsection{National Laws and Policies}

Constitutional provisions regarding the right to a healthy environment and the sustainable use of living natural resources appear in the Namibian Constitution, but not in those of the other countries. The Canadian constitution is silent on the matter of environmental health and the sustainable use of living natural resources (e.g. Boyd 2012, 2013), though Kendrick (2012) notes that the rights of Inuit to hunt, fish and trap are included in the 1982 Constitution.

In the US, the Marine Mammal Protection Act Section 101(b) (commonly called the "Native exemption") specifically allows Alaskan Natives to take seals (and other marine mammals) for subsistence and creation of Native handicrafts, as long as this taking is not done in a wasteful manner, and the population being harvested is healthy. No permit is required.

The management of seals in most countries (e.g. Canada and Namibia) is governed by marine and fisheries legislation in which seals are included in the definition of "fish". Marine resource legislation in all of the countries reviewed makes provision for the hunting of seals under permit. Provisions include hunting for subsistence and for the protection of fisheries. In Canada, Norway, and Namibia permits are issued for commercial hunting of seals, and hunts are overseen by government officials and in some cases by independent observers. In the European Union, fishery and environmental matters are governed centrally through such legislation as the Habitats Directive, with which national legislation is required to comply.

The countries involved in commercial sealing have developed clear regulations governing the humane procedures to be adopted in killing seals. This nevertheless remains a controversial issue and it is not clear to what extent the Namibian seal hunt has met the recommendations made by the Ombudsman of Namibia (Walters 2012a, 2012b) to improve their methods.

As at the international level, national legal frameworks regarding seals make provision for the harvesting of seals and, in some cases, the killing of seals to protect fisheries. The conditions under which permits to hunt or kill seals are issued are mostly carefully specified, as are the methods that may be used to kill seals. How these legal and policy frameworks and regulations actually play out in practice has not been specifically investigated, and some measure of ground truthing is needed.

\subsection{Seal population status, trends and harvests}

The estimation of population numbers of seals is overseen by national and international wildlife agencies. The agencies involved vary by region. In the North Pacific, populations and trends of northern fur seals are updated annually by NMFS and Russian fishery management agencies. Populations of harbour seals on the Pacific coastline of both the USA and Canada are monitored by NMFS and DFO Canada. For US waters, available information on abundance, trend, and human takes of all marine mammals is provided in annual Stock Assessment Reports prepared by NMFS. For the North Atlantic waters, ICES, NAMMCO and the Joint Norway-Russia Commission on Fisheries are involved at an international level. DFO Canada and the Norwegian Ministry of Fisheries and Coastal Affairs Institute of Marine Research conduct periodic surveys and monitor seal population trends in their waters.

European Union directives provide an overarching framework for the conservation and management of seals by countries within the EU. HELCOM provides oversight and advice on the management of seals in the Baltic Sea, and Finland and Sweden have national management plans for seals in their respective waters. Seals in the Wadden Sea are monitored and managed within the agreement between Netherlands, Germany and Denmark. The most intensively monitored seal populations are those in the British Isles. 
Table 10.2 Summary of status and trends of the major seal populations covered in this report

\begin{tabular}{|c|c|c|c|c|c|}
\hline Species & Sea /Locality & $\begin{array}{c}\text { Population } \\
\text { size }\end{array}$ & Trend & $\begin{array}{l}\text { Growth } \\
\text { rate }\end{array}$ & Comments \\
\hline \multirow[t]{3}{*}{ Harp } & Northwest Atlantic/Baffin Bay & $7,000,000+$ & $\uparrow$ & & \\
\hline & Greenland Sea (West Ice) & 627,410 & $\rightarrow$ & & ICES (2015) data \\
\hline & Barents/White Sea & $1.360,000$ & 个 & & \\
\hline \multirow[t]{2}{*}{ Hooded } & Labrador/Newfoundland & 593,500 & $\uparrow$ & & \\
\hline & Greenland Sea & 85,000 & $\downarrow$ & & Currently below N 30\% ${ }^{27}$ \\
\hline \multirow[t]{5}{*}{ Ringed } & Baffin Bay & $1,200,000$ & $?$ & & \\
\hline & Beaufort Sea & $?$ & $?$ & & \\
\hline & Baltic Sea & 5,000 & $\uparrow$ & $5 \%$ & \\
\hline & Russian Arctic seas & $?$ & $?$ & & \\
\hline & Alaska - Bering \& Chukchi seas & $?$ & $?$ & & \\
\hline \multirow[t]{5}{*}{ Grey } & Canada - Front \& Gulf & 500,000 & $\uparrow$ & $?$ & \\
\hline & New England & $?$ & 个 & & \\
\hline & British Isles / North Sea & 120,000 & $\uparrow$ & $10 \%$ & \\
\hline & Baltic Sea & 27,500 & 个 & $10 \%$ & \\
\hline & Norwegian Sea & $?$ & $\boldsymbol{T}$ & & \\
\hline \multirow[t]{7}{*}{ Harbour } & Alaska & 152,602 & $?$ & & \\
\hline & Canada - Front \& Gulf & 20,000 & 个 & & \\
\hline & USA East Coast & 99,340 & 个 & & \\
\hline & USA West Coast & 60,000 & $?$ & & Data pre-2000 \\
\hline & British Isles & 37,000 & $\uparrow$ & & \\
\hline & Baltic Sea & $?$ & 个 & & \\
\hline & Norwegian Sea & $?$ & 个 & & \\
\hline \multirow{3}{*}{$\begin{array}{l}\text { Northern } \\
\text { Fur }\end{array}$} & NE Pacific & 639,545 & $\downarrow$ & & \\
\hline & San Miguel Island & 9,968 & $\uparrow$ & & \\
\hline & Western Pacific & $?$ & $?$ & & \\
\hline \multirow[t]{2}{*}{ Cape Fur } & Namibia & $1,200,000$ & $\uparrow$ & & \\
\hline & South Africa & 700,000 & $\rightarrow$ & & \\
\hline Crabeater & Antarctic & $9,500,000$ & $?$ & & \\
\hline
\end{tabular}

The methods used to estimate seal populations are costly and are often based on counts of pups on breeding grounds combined with the use of correction factors to correct for the numbers of subadults and adults hauled out on ice or beaches, or at sea. For some species, such as ringed seals, these methods are not applicable (pups are born over vast areas and in snow lairs where they are hard to detect) and estimates of ringed seal numbers remain highly uncertain for most areas. Estimates of seal numbers and trends are summarised in Table 10.2. No strong evidence has been found to indicate that the nationally and internationally agreed upon numbers reported are deeply flawed or represent major over- or underestimates.

27 / i.e. the population size is less than $30 \%$ of the maximum population estimated or inferred and is the limit at which all harvesting of nay sort must stop. 
The annual TACs for harp seals and Cape fur seals have been challenged by animal welfare groups (e.g. websites of HSI, IFAW) and by scientists on the grounds that the precautionary principle is not being implemented (Leaper et al 2010). Commercial catches of harp and Cape fur seals in recent years have generally been well below allocated TACs (Table 10.3). Greenland does not allocate overall TACs. The numbers of seals of each species to be harvested and where they are harvested is supposedly decided at the local municipal level each year (Government of Greenland 2012a) but it is not clear whether this happens in practice. Subsistence harvests of seals in northern Canada and Alaska are regulated by national government agencies and by local communities, often through co-management agreements (e.g. Marine Mammal Commission 2008). These arrangements appear to vary across the region and precise details of how they operate have not been located. No recent information on the subsistence harvesting of seals in the Russian Federation has been found.

Two seal populations included in this review have shown recent declines. The northern fur seal population centred on the Pribilof Islands is declining from unknown causes. The hooded seal population in the NE Atlantic declined due to overharvesting as result of overestimates of population size. Numbers appeared to stabilise once a zero quota was set but the most recent estimates indicate a further decline (K. Kovacs, pers. comm. 2015). Other populations of these two species are stable or increasing. The status of ringed seals in most of their range is unknown. The Cape fur seal population is considered to be stable in South Africa but expanding along the Namibia coast. Populations of harbour and grey seals appear, for the most part, to be stable or recovering and trends in crabeater seals are unknown.

The overall conclusion regarding the seal populations discussed in this report is that populations are generally stable or increasing, apart from two known subpopulations and possibly some populations of ringed seals. Existing harvest levels appear to be sustainable but infrequent censuses, and their often low levels of accuracy, mean that only major changes in numbers and trends are likely to be detected (Taylor et al. 2007) and in this context the precautionary principle, within the context of sustainable use, should be applied (see Cooney 2004, IUCN 2007). Furthermore, habitat deterioration in circumpolar regions is likely to impact negatively on seal populations that depend on sea ice.

The global population of the eight species amounts to more than 20 million seals. Excluding crabeater seals, the global population of seals subjected to human use of one sort or another amounts to about 13.9 million seals (Table 10.3) of which less than $2.2 \%$ are harvested annually (i.e. if the total take is about 300,000 seals). Seal mortality from fisheries by-catch and fisheries associated culling appears to be poorly monitored and the overall current extent of human caused mortality, besides that reported in commercial harvesting and the reported annual take in Greenland, is not known. This topic is discussed further below under section 10.5 below. 
Table 10.3 Summary of seal harvests and other mortality

\begin{tabular}{|c|c|c|c|c|c|}
\hline Country & Seal species & TAC & Annual Harvest & $\begin{array}{l}\text { Other } \\
\text { mortality }\end{array}$ & Notes \\
\hline \multicolumn{6}{|c|}{ 1. Commercial Harvests } \\
\hline \multirow[t]{3}{*}{ Canada } & Harp & 400,000 & 67,200 & & Av. annual catch 2009-2014 \\
\hline & Hooded & & $<200$ & & Last 5 years \\
\hline & Grey & 12,000 & $<5,000$ & & \\
\hline \multirow[t]{3}{*}{ Norway } & Harp & 25,000 & 10,593 & & \\
\hline & Hooded & 0 & 21 & & Research take \\
\hline & Grey & $?$ & 179 & & \\
\hline Namibia & Cape fur & 92,000 & 45,610 & & Av. for 3 years \\
\hline \multicolumn{6}{|c|}{ 2. Subsistence Harvests } \\
\hline \multirow[t]{3}{*}{ Greenland } & Harp & - & 77,830 & & Av annual catch 1993-2009 \\
\hline & Ringed & - & 79,206 & & “ \\
\hline & Hooded & - & 5,867 & & “ \\
\hline USA - Pribilof Is. & Northern fur & 2,500 & 378 & & For 2013 \\
\hline $\begin{array}{l}\text { USA - Northern } \\
\text { Alaska }\end{array}$ & Ringed & - & 2,000 to 10,000 & & \\
\hline $\begin{array}{l}\text { USA - Southern } \\
\text { Alaska }\end{array}$ & Harbour & - & 1,737 & & Average for 2004-2008 \\
\hline Northern Canada & & $?$ & $?$ & & \\
\hline Russia & & $?$ & $?$ & & \\
\hline \multicolumn{6}{|c|}{ 3. Other human caused mortality } \\
\hline \multirow[t]{2}{*}{ USA East Coast } & Grey & - & - & 928 & \\
\hline & Harbour & - & - & 332 & \\
\hline USA West Coast & Harbour & - & - & 40 & \\
\hline \multirow[t]{2}{*}{ South Africa } & Cape Fur & - & - & 3,327 & In bycatch (1990s) \\
\hline & Cape fur & - & - & 1,400 & Killing during fishing (1990s) \\
\hline \multirow[t]{3}{*}{ Europe } & Grey & - & - & $?$ & \\
\hline & Harbour & - & - & $?$ & \\
\hline & Ringed & - & - & $?$ & \\
\hline
\end{tabular}

\subsection{Extra-territorial impacts of policies}

The 1972 USA ban on the import of seal products will have affected exports of furs, seal oil and meat from Canada, Alaska, and elsewhere, but reports or analysis of these likely social and economic impacts have not been found.

The temporary 1982-1989 European Union moratorium on the import of seal products had a major impact on the seal fur trade and on rural communities in Canada (Royal Commission 1986a and1986b). The more recent ban (advocated in 2006, implemented in 2009, and supported by the WTO in 2014) on the import of seal products into the European Union has impacted trade in seal furs from Canada, Greenland and Norway. Possible impacts on the Namibian sealing industry do not appear to have been investigated, or at least have not been reported upon. The inclusion of exemptions in the EU ban for the import of seal skins produced by indigenous communities has not lessened the impacts of the ban on indigenous communities, primarily because market prices of pelts collapsed (see Fig. 2.4). Governments of Canada, Greenland and Norway introduced subsidies in an attempt to mitigate some of the effects of the EU and Russian bans on the livelihoods of rural households in remote coastal areas. No recent 
reports or analyses of the impacts of the EU and Russian ban on livelihoods of households that may previously have depended to a significant degree on trading seal products have been located.

The existence of regional organisations such as ICES, HELCOM, NAMMCO, and Joint Commissions, such as that formed between Norway and Russia, provide fora in which direct seal management issues between countries can be resolved. Apart from the wide-ranging effects of trade bans on seal products, there does not appear to be any other significant extra-territorial impacts of policies on seal management.

Possible indirect extra-territorial effects of fisheries policies (as opposed to those directly related to seals) have not been investigated.

\subsection{Seal-fishery conflicts and ecosystem management}

Conflicts between seals and fisheries are bi-directional in that seals impact fishing operations, and fishing can have adverse impacts on seals. The impacts may be direct, as in fisheries bycatch of seals and seals damaging fish catches and fishing gear, or indirect, through effects on marine food webs and ecosystems resulting from predation by seals or fisheries, or both. Perceived impacts of seals on fisheries, particularly on inshore, small-scale fisheries and fish farms, are widespread. In part, these perceptions arise from increasing populations of grey and harbour seals and from historical bounty hunting traditions that were employed in Europe and North America to reduce seal predation on fish (Table 10.4). These perceptions apply to a range of marine mammalian predators - as they do to terrestrial carnivores that take domestic livestock or selected game species.

Efforts are being made in European waters, and particularly in the Baltic Sea, to develop seal proof gear, in tandem with compensation schemes to fishers suffering damage to their gear and catch losses (Anonymous 2001b, 2007b, Westerberg 2010, Königson 2011, Königson and Lunneryd 2012). In Scotland, where grey seals impact salmon fisheries and fish farms, attempts to achieve seal conservation objectives while mitigating their impacts on fisheries are being made through the development of local management plans with community participation (e.g. Butler et al 2008, Butler et al 2011).

Fisheries bycatch of marine mammals is an important source of human induced mortality (Wickens 1995). Read et al. (2006) investigated marine mammal bycatch in US fisheries and reported a mean annual bycatch of marine mammals of 6,215 from1990 to 1999 although the annual bycatch declined significantly during this period. However, the overall decline was mainly due to a decline in cetacean bycatch. Pinniped bycatch in US fisheries did not decline significantly, with a mean annual bycatch of 3,187 (range 2,091-5,808). Using the number of fishing vessels in US fisheries and an estimate of the number of vessels fishing globally, Read et al. (2006) provided estimates of marine bycatch mortality in gillnets, trawls, and 'other' for 1990 to 1994. Mean annual global bycatch of pinnipeds calculated from Read et al. (2006, Table 2) was 345,612 pinnipeds with a range of 186,738-572,771 for the period 1990 to 1994. These levels of mortality as a result of fisheries bycatch, if they still occur, exceed the recently recorded commercial and subsistence harvest of approximately 300,000 seals from the eight species dealt with in this report. More recent analyses indicate that mitigation efforts have made little impact at a global level on the extent of fisheries bycatch, which remains a serious conservation and fisheries management issue (e.g. Davies et al. 2009, Lewison et al. 2004, Moore et al. 2009, Lewison et al. 2014). 
Table 10.4 Summary of seal species population trends in different seas and perceived adverse impacts of seals on fisheries, and of fisheries on seals

\begin{tabular}{|c|c|c|c|}
\hline Species & Sea /Locality & Trend & Perceived seal - fishery conflicts \\
\hline \multirow[t]{3}{*}{ Harp } & $\begin{array}{l}\text { Northwest Atlantic/Baffin } \\
\text { Bay }\end{array}$ & $\uparrow$ & No? \\
\hline & Greenland Sea (West Ice) & $?$ & No? \\
\hline & Barents/White Sea & $\uparrow$ & Impacts on capelin but cod stocks are at highest recorded levels \\
\hline \multirow[t]{2}{*}{ Hooded } & Labrador/Newfoundland & $\uparrow$ & No? \\
\hline & Greenland Sea & $\downarrow / \rightarrow$ & No? \\
\hline \multirow[t]{5}{*}{ Ringed } & Baffin Bay & $?$ & No \\
\hline & Beaufort Sea & $?$ & No \\
\hline & Baltic Sea & $\uparrow$ & Yes, raiding fish farms and traps / developing seal proof gear \\
\hline & Russian Arctic seas & $?$ & $?$ \\
\hline & $\begin{array}{l}\text { Alaska - Bering \& Chukchi } \\
\text { seas }\end{array}$ & ? & No \\
\hline \multirow[t]{5}{*}{ Grey } & Canada - Front \& Gulf & $\uparrow$ & Yes, affecting recovery of cod fishery \\
\hline & New England & $\uparrow$ & Yes, perceptions of increasing seal impacts on fisheries \\
\hline & British Isles / North Sea & $\uparrow$ & Yes, salmon fisheries and farms / seal culling / community mgmt. \\
\hline & Baltic Sea & $\uparrow$ & Yes, raiding fish farms and traps / developing seal proof gear \\
\hline & Norwegian Sea & $\uparrow$ & Yes, official reason for maintaining grey seal harvest \\
\hline \multirow[t]{8}{*}{ Harbour } & Canada - Front \& Gulf & $\boldsymbol{T}$ & $?$ \\
\hline & Alaska & $?$ & $?$ \\
\hline & New England & $\uparrow$ & Yes, general perception of impacts on fisheries \\
\hline & USA West Coast & $?$ & $?$ \\
\hline & British Isles & $\uparrow$ & Yes \\
\hline & Baltic Sea & $\uparrow$ & Yes \\
\hline & Norwegian Sea & $\uparrow$ & Yes \\
\hline & Wadden Sea & $\uparrow$ & Yes \\
\hline \multirow{3}{*}{$\begin{array}{l}\text { Northern } \\
\text { Fur }\end{array}$} & NE Pacific & $\downarrow$ & Fishing gear causing mortality \\
\hline & San Miguel Island & $\uparrow$ & Fishing gear causing mortality \\
\hline & North-western Pacific & $?$ & $?$ \\
\hline \multirow[t]{2}{*}{ Cape Fur } & Namibia & $\uparrow$ & Perception of seals reducing fisheries catch but no supporting evidence \\
\hline & South Africa & $\rightarrow$ & Bycatch and killing of seals $(>5,000$ seals $/ \mathrm{yr})$ in $1990 \mathrm{~s}$. \\
\hline Crabeater & Antarctic & $?$ & Expanding krill fishery may have an impact \\
\hline
\end{tabular}

In larger offshore commercial fisheries, large, or increasing, seal populations are frequently linked to declining stocks of particular fish species, or to the failure of a particular fish stock to recover. Examples range from political statements justifying seal culls on the basis of the quantities of fish eaten by seals (that presumably could be eaten by humans) to the results of sophisticated predator-prey population models that link seal predation to declines or lack of recovery in fish stocks. Examples include the controversy over seal/capelin stocks in the Barents Sea (e.g. Hjermann et al 2004, 2007) and the failure of cod to recover in Canadian waters as a result of predation by grey, harp and hooded seals (e.g. Bundy 2001, Morissette et al 2006).

Increasingly, there is now a shift away from viewing cause and effect relationships in seal-fisheries interactions in terms of simple single predator-prey species interactions to an appreciation of the full 
complexity of marine food webs and the adoption of ecosystem approaches to their management. As Travis et al (2014) argue there is a need for fisheries science and management to appreciate "the nature, strength, complexity, and outcome of species interactions" and to understand "that networks of interacting species exhibit nonlinear dynamics and feedback loops that can produce sudden and unexpected shifts" to alternate states as thresholds are crossed (e.g. Jackson 2001, Jackson et al. 2001, Scheffer and Carpenter 2003, Lotze and Milewski 2004, Baum and Worm 2009, Eero et al. 2011).

Cassini et al. (2012), for example, explored source-sink interactions between the main basin and the Gulf of Riga in the Baltic Sea. A rapid increase in cod in the Baltic Sea during the 1970s resulted in a spillover of cod into the Gulf of Riga, which set in motion trophic cascades involving herring, copepods and cladocerans that persisted after the cod population in the Gulf of Riga collapsed. The key feature of this example is that it highlights the importance of cross-system fluxes and the role of top predators in structuring ecosystems.

Research on the Benguela upwelling system along the western coast of southern Africa shows that it comprises four ecologically distinct components (Hutchings et al. 2009), which result in decadal-scale variability in its structure and the abundance and distribution of important organisms in the ecosystem (van der Lingen et al. 2006), which has implications for the management of fisheries and Cape fur seals. The food web of the Benguela ecosystem was one of the most completely parameterised available and Yodzis (1998) used this to examine the likely impacts of culling seals on returns to anchovy and halibut fisheries. He found that a cull of Cape fur seals was more likely to reduce total yields of exploited fish species than it was to increase them. A comparison of the extent of predation in marine systems by mammals, birds, fish and fisheries shows the extent to which fish dominate biomass flows and predation in marine systems (Table 10.5). However, while marine mammal, bird, and fish predation circulates within the marine system, human predation does not as biomass taken by fisheries is largely removed from the ecosystem. The extent to which fisheries harvests can change ecosystems over time is well illustrated by changes in the landings for bottom trawl fisheries off England and Wales. Thurston et al. (2010) used historical records dating back to 1889 and landings per unit power (LPUP - a measure of productivity of commercial fisheries) to show that during a period of 118 years LPUP had declined by $94 \%$.

Table 10.5 Estimated biomass flow to mammals, birds, fish and fisheries in six ecosystems (Data from Bax 1991 in Yodzis 2001)

\begin{tabular}{|l|r|r|r|r|}
\hline \multirow{2}{*}{ Ecosystem } & \multicolumn{4}{|c|}{ Annual mass of fish taken (tonnes.km-2) } \\
\cline { 2 - 5 } & Mammals & Birds & Fish & Fisheries \\
\hline Benguela Current & 2.6 & 0.3 & 56.5 & 1.6 \\
\hline Georges Bank & 5.4 & 2.0 & 42.5 & 6.1 \\
\hline Balsfjord & 00 & 0.0 & 14.1 & 1.5 \\
\hline Eastern Bering Sea & 1.5 & 0.2 & 11.0 & 1.4 \\
\hline North Sea & 0.1 & 0.6 & 7.0 & 4.4 \\
\hline Barents Sea & 3.0 & 0.0 & 5.1 & 1.8 \\
\hline
\end{tabular}

\subsection{Economics of seal harvesting and livelihood issues}

Annual commercial seal hunts are undertaken by Canada, Norway and Namibia. Commercial sealing in Canada is subsidised by the Federal and Newfoundland (Provincial) governments (Anonymous 2001a). The Norwegian Government ended its annual sealing subsidy of \$1.6 million in December 2014. The extent, if any, of government subsidies to sealing in Namibia are unknown. Two studies, one in Canada 
(Anonymous 2001a) and one in Namibia (Campbell et al. 2011) have examined the financial returns from commercial sealing in relation to national gross domestic product (GDP) and potential alternative industries. Both studies advocated the closure of seal hunts on the grounds that they contributed little to national economies and should be replaced by creating alternative livelihoods for those involved. In the case of Namibia the authors argued that greater financial returns were earned from eco-tourism (visitors to a seal colony) than sealing and that continuing seal hunts would prejudice returns from tourism. In the case of Newfoundland it was argued that a growing and diversifying economy would be able to absorb those involved in commercial sealing. Neither of these reports considered the legitimacy of the sustainable use of natural renewable resources, or the rights of individuals to pursue legally sanctioned livelihoods, no matter how small their contribution to the national economy.

Subsistence harvesting of seals occurs in Alaska, northern Canada, Greenland, Sweden, and the Russian Federation. A great deal of confusion surrounds the term subsistence harvesting. For many in western cultures it is defined as harvesting for own use with traditional tools, and excludes trade or monetary return. For example, the US MMPA addresses this issue directly stating in Section 101(b)(2) that the prohibition on taking does not apply to Alaska Natives if the taking "is done for purposes of creating and selling authentic native articles of handicrafts and clothing: Provided, That only authentic native articles of handicrafts and clothing may be sold in interstate commerce: And provided further, That any edible portion of marine mammals may be sold in native villages and towns in Alask a or for native consumption." In the context of aboriginal harvesting in the Arctic and sub-Arctic regions where the household is the central economic unit in a mixed subsistence based economy, subsistence harvesting that includes commercial trade is an integral component of household production (Usher et al. 2003). It is more fully characterised by Usher (2003 et al., page 185) as follows and in Fig. 10.1:

"1. The local economy consists of both market and subsistence spheres, and many if not most households are oriented to both of these spheres, not exclusively to one or the other.

2. Income flows to households from both of these spheres in the form of wages, commodity production, and transfers (cash income), and of subsistence (income in kind).

3. The household deploys the factors of production available to it (land, labour, capital) so as to capture these sources of income, in a flexible manner.

4. Household success requires successful integration of market activities, subsistence production, and household reproduction. The model explicitly rejects the assumption that those without paid jobs are "unemployed" and hence make no productive contribution to economic well-being.

5. Individuals maximize their ability to provide for their house- holds not necessarily by having a single skill, occupation, or job, but several. Nor is it appropriate to assume that individuals derive their livelihood from any single sector of the regional economy.

6. There is substantial cooperation and sharing among households, generally along lines of kinship, to optimize these flows of income and to ensure a general distribution of benefits.

7. Most importantly, because there are not two separate economies, people do not choose between living in a "traditional" economy or "modern" economy, nor are they in transition between the two. The modern economy in northern communities is in fact a mixed, subsistence-based economy."

And further in Usher et al. (2003, pages 177-178)

"Thus, subsistence activity does not constitute a separate and distinct economy in northern communities, but is combined, at the individual, the household, and the village level with wage labour and transfer payments. People move between subsistence and market activities, depending on opportunities and preference in a mixed economy thus acts like a sponge, absorbing labour when other opportunities decline, and releasing it when they arise. Measures of the 
bealth and viability of the contemporary subsistence system should therefore include its absorptive capacity and resilience." [emphasis added]

On the east coast of Baffin Island in the 1970s ringed seals were the only harvest that provided both food and money when, following centralisation of households into large regional settlements, it became necessary to use snowmobiles (instead of dogs) to reach more distant hunting grounds (Wenzel 1986). The sale of furs and narwhal ivory met $75 \%$ of a hunter's cash needs to operate and maintain harvesting equipment, of which the sale of ringed seal skins provided 44\% (Wenzel 1986). The flexible interchange between harvesting for household food, sharing food, trade in harvested items such as furs, and wage earning is central to Inuit household production and coping strategies and seals form a key component of their subsistence harvests (e.g. Chabot 2003, Harder and Wenzel 2012). A comparison of Inuvialuit harvesting in the Beaufort Sea in the 1960s and 1990s revealed that, contrary to expectations, country foods and hunting persisted as an important component of household economies (Usher 2002). There were, however, changes in the composition of hunters' harvests, with a decline in the total amount harvested per hunter $(2,083 \mathrm{~kg} /$ year in the $1960 \mathrm{~s}$ to $707 \mathrm{~kg} /$ year in the $1990 \mathrm{~s})$ and a change in the ratio of marine to terrestrial foods from 75:25 in the 1960s to 45:55 in the 1990s. Usher (2002) considered the near abandonment of the use of dogs to be a major contributing factor in bringing about these changes.

Given the complexities and diversity of subsistence harvesting strategies across the Arctic it is perhaps not surprising that little data exists regarding the financial aspects of subsistence sealing or the role it plays in local economies. Thus, it must be stressed, that the information provided in this report under "economics of seal harvesting" for both commercial and subsistence sealing is fragmentary and financial information is incomplete. Economic analysis involves both a more complete examination of financial costs and benefits, as well as the effects of government policies and price distortions on the values of land, resources, labour, exchange rates, non-market goods and services, and the value of enterprises to the economy as a whole. Studies of seal harvesting involving a full economic analysis and evaluation of benefits and costs to society at local and national levels have yet to be carried out. 


\section{REFERENCES}

\subsection{Literature cited}

Allen, B.M., \& Angliss. R.P. (2013) Alaska marine mammal stock assessments, 2012. U.S. Dep. Commer., NOAA Tech. Memo. NMFS- AFSC-245, 282 p.

Allen, B. M., \& R. P. Angliss (2014) Alaska marine mammal stock assessments, 2013. U.S. Dep. Commerce., NOAA Tech. Memo. NMFS- AFSC-277, 294 p.

Amendments to the Marine Mammal Regulations - Seal Harvest. http://www.dfompo.gc.ca/media/back-f... [Accessed 16/07/2014]

Anonymous (2001a) The Economics of the Canadian Sealing Industry. Canadian Institute for Business and the Environment, Montreal Quebec, 32 pp.

Anonymous (2001b) National management plan for grey seal stock in the Baltic Sea. Swedish Environmental Protection Agency, Stockholm.

Anonymous (2007a) Danish non paper on seal skin bans. [Accessed 24/07/14] http://www.sealsandsealing.net/resources/Greenland_ban_paper.pdf

Anonymous (2007b) Management Plan for the Finnish Seal Populations in the Baltic Sea. Ministry of Agriculture and Forestry, Helsinki, Finland.

http://www.mmm.fi/en/index/frontpage/Fishing,_game_reindeer/hunting_game_management /managementplans/seal_populations.html [Accessed 18/06/2014]

Arneberg, P., Titov, O., Filin, A., \& Stiansen, J. E. (eds.) (2013) Joint Norwegian-Russian environmental status report on the Barents Sea Ecosystem - update for current situation for climate, phytoplankton, zooplankton, fish and fisheries in 2011. IMR/PINRO Joint Report Series, 2013(3), 56 pp. ISSN 1502-8828.

Baum, J.K. \& Worm, B. (2009) Cascading top-down effects of changing oceanic predator abundances. Journal of Animal Ecology, 78, 699-714.

Bax, N.J. (1991) A comparison of fish biomass flow to fish, fisheries, and mammals in six marine ecosystems. ICES Marine Science Symposium, 193, 217-224.

Belikov, S.E. \& Boltunov, A.N. (1998) The ringed seal (Phoca hispida) in the western Russian Arctic. NAMMCO Scientific Publications, 1, 63-82.

Belyakova, E. (2009) The conflict over seal bunting in Russia. Masters Thesis, University of Oslo, Norway. Accessed 31/07/14. https://www.duo.uio.no/bitstream/10852/32712/1/MasterxsxThesisxSUMx4091.pdf

Blanchet, C. \& Rochette, L. (2008). Nutrition and Food Consumption Among the Inuit of Nunavik. Nunavik Inuit Health Survey 2004/Qanuippitaa? How are we? Institut national de santé public du Québec, Nunavik Regional Board of Health and Social Services.

Bonner, W.N. (1982) Seals and man: a study in interactions. University of Washington Press, Seattle, Washington.

Bousquet N., Chassot E., Duplisea D.E. \& Hammill, M.O. (2014) Forecasting the Major Influences of Predation and Environment on Cod Recovery in the Northern Gulf of St. Lawrence. PLoS ONE 9(2): e82836. doi:10.1371/journal.pone.0082836

Boyd, D.R. (2012) The constitutional right to a healthy environment. Environment Magazine, July-August, 2012, [Accessed 17/07/2014]

Boyd, D.R. (2013) Constitutional Recognition of the Right to a Healthy Environment: Making a Difference in Canada. Suzuki Foundation, White Paper \#1, 39 pp. [Accessed 17/07/14] 
Bundy, A. (2001) Fishing on ecosystems: the interplay of fishing and predation in NewfoundlandLabrador. Canadian Journal of Fisheries and Aquatic Sciences, 58, 1153-1167.

Bunnefeld, N., Hoshino, E. \& Milner-Gulland, E.J. (2011) Management strategy evaluation: a powerful tool for conservation? Trends in Ecology and Evolution, 26, 441-447.

Bunnefeld, N. \& Keane, A. (2014) Managing wildlife for ecological, socioeconomic, and evolutionary sustainability. Proceedings of the National Academy of Sciences, 111, 12964-12965.

Butler, J.R.A. (2011) The challenge of knowledge integration in the adaptive co-management of conflicting ecosystem services provided by seals and salmon. Animal Conservation, 14, 599-601.

Butler, J.R.A., Middlemas, S.J., Graham, I.M. \& Harris, R.N. (2011) Perceptions and costs of seal impacts on Atlantic salmon fisheries in the Moray Firth, Scotland: implications for the adaptive comanagement of seal-fishery conflict. Marine Policy, 35, 317-323.

Butler, J.R.A., Middlemas, S.J., McKelvey, S.A., McMyn, I., Leyshon, B., Walker, I., Thompson, P.M., Boyd, I.L., Duck, C., Armstrong, J.D., Graham, I.M. \& Baxter, J.M. (2008) The Moray Firth Seal Management Plan: an adaptive framework for balancing the conservation of seals, salmon, fisheries and wildlife tourism in the UK. Aquatic Conservation: Marine and Freshwater Ecosystems, 18,1025-1038.

Butterworth, A., Gallego, P., Gregaory, N., Harris, S. \& Soulsbury, C. (2007) Welfare aspects of the Canadian seal hunt: final report. 45pp [Accessed 19/06/14] Document requested by HSUS and submitted to EFSA 2007 http:/ / www.harpseals.org/politics_and_propaganda/welfareaspectsofcanadiansealhunt_butterworth.pdf

Butterworth, A. \& Richardson, M. (2013) A review of animal welfare implications of the Canadian commercial seal hunt. Marine Policy, 38, 457-469.

Butterworth, A. \& Richardson, M. (2014) A review of animal welfare implications of the Canadian commercial seal hunt - a response to critique of paper MP13 172. Marine Policy, 43, 379-381.

Campbell, R., Knowles, T. \& O’Connor, S. (2011) The economics of seal hunting and seal watching in Namibia. A report for Humane Society International, World Society for the Protection of Animals, Bont Voor Dieren (NL) and Respect for Animals (UK). Economists at Large, Melbourne, Australia.

Carretta, J.V., E. Oleson, D.W. Weller, A.R. Lang, K.A. Forney, J. Baker, B. Hanson, K. Martien, M.M. Muto, M.S., Lowry, J. Barlow, D. Lynch, L. Carswell, R. L. Brownell Jr., D. K. Mattila, \& M.C. Hill. (2013) U.S. Pacific Marine Mammal Stock Assessments: 2012. U.S. Department of Commerce, NOAA Technical Memorandum, NMFS-SWFSC-504. 378 pp. http://www.afsc.noaa.gov/Publications/assessments.htm

Casini, M., Blenckner, T., Möllmann, C., Gårdmark, A., Lindegren, M., Llope, M., Kornilovs, G., Plikshs, M. \& Stenseth, N.C. (2012) Predator transitory spillover induces trophic cascades in ecological sinks. Proceedings of the National Academy of Sciences, 109, 8185-8189.

Chabot, M. (2003) Economic changes, household strategies, and social relations of contemporary Nunavik Inuit. Polar Record, 39, 19-34.

Cioppa, T. (1995) The Exploitation of Antarctica's Natural Resources and the Evolution of the Antarctic Treaty System: An Overview. IBRU Boundary and Security Bulletin Autumn, pages 59-66. Accessed 23/06/14. https://www.dur.ac.uk/ibru/publications/download/?id=72

Cochrane, K.L., Augustyn C.J., Cockcroft, A.C., David, J.H.M., Griffiths, M.H., Groeneveld, J.C., Lipinski, M.P., Smale, M.J., Smith, C.D., \& Tarr, R.J.Q. (2004) An ecosystem approach to fisheries in the southern Benguela context. African Journal of Marine Science 26, 9-35

Cooney, R. (2004) The Precautionary Principle in Biodiversity Conservation and Natural Resource Management: An issues paper for policy-makers, researchers and practitioners. IUCN, Gland, Switzerland and Cambridge, UK. xi + 51pp. 
Conservation of Natural habits regulation 44 http://www.legislation.gov.uk/uksi/1994/2716/regulation/44/made [Accessed 9/08/14]

Constable, A.J., de la Mare, W.K., Agnew, D.J., Everson, I. \& Miller, D. (2000) Managing fisheries to conserve the Antarctic marine ecosystem: practical implementation of the Convention on the Conservation of Antarctic Marine Living Resources (CCAMLR). ICES Journal of Marine Science, 57, 778-79.

Convention for the Conservation of Antarctic Seals - 1972. http://www.antarctica.ac.uk/about_antarctica/geopolitical/treaty/update_1972. [Accessed 28/06/14]

Convention on the Conservation of Antarctic Marine Living Resources. http://www.antarctica.ac.uk/about_antarctica/geopolitical/treaty/convention.php [Accessed 27/06/14]

Corkeron, P.J. (2006) Opposing views of the "Ecosystem Approach" to fisheries management. Conservation Biology, 20, 617-619.

Corkeron, P.J. (2009) Marine mammals' influence on ecosystem processes affecting fisheries in the Barents Sea is trivial. Biology Letters, 5, 204-206.

COSEWIC (2010) COSEWIC assessment and status report on the Northern Fur Seal Callorbinus ursinus in Canada. Committee on the Status of Endangered Wildlife in Canada. Ottawa. x +50 pp. http://www.sararegistry.gc.ca/status/status_e.cfm. Accessed 20/06/14.

Coulibaly, M. (2010) The 2009 EU Regulation on Trade in Seal Products. [Accessed 16/07/14] http://works.bepress.com/mohamed_coulibaly/1

Council of Canadian Academies (2014) Aboriginal Food Security in Northern Canada: An Assessment of the State of Knowledge, Ottawa, ON. The Expert Panel on the State of Knowledge of Food Security in Northern Canada, Council of Canadian Academies.

Daoust, P-Y., Caraguel, C., Fenton, H. Hammill, M., Roy, L.D. \& Spears, J. (2011) Assessment of current and alternative methods for killing young grey seals (Halichoerus grypus) during commercial harvest. Research Document 2012/nnn. ISSN 1919-5044 (Online / En ligne) www.dfompo.gc.ca/csas-sccs

Daoust, P-Y., Hammill, M., Stenson, G. \& Caraguel, C. (2014) A review of animal welfare implications of the Canadian commercial seal hunt: A critique. Marine Policy, 43, 367-371.

Dauvergne, P. \& Neville, K.J. (2011) Mindbombs of right and wrong: cycles of contention in the activist campaign to stop Canada's seal hunt. Environmental Politics, 20, 192-209.

Davies, R.W.D., Cripps, S.J., Nickson, A. \& Porter, G. (2009) Defining and estimating global marine fisheries bycatch. Marine Policy, 33, 661-672.

De Klerk, S. (2013) Seal harvesting in Namibia: a critical analysis. Bachelor of Laws Dissertation, University of Namibia, Windhoek, Namibia. 102pp.

DeMaster and Sisson (1992) Pros and cons of pinniped management along the north American coast to abet fish stocks., Wildlife 2001, Populations (eds D. McCullough \& R. Barrett), pp. 321-330, Springer, Netherlands.

De Vooys, K.G.N., Brasseur, S.M., van der Meer, J. \& Reijnders, P.J.H. (2012) Analyses of four centuries of bounty hunting on seals in Zeeland, SW-Netherlands. Lutra, 55, 55-65.

DFO (2010) 2011-2015 Integrated Fisheries Management Plan for Atlantic Seals. (http://www.dfompo.gc.ca/fm-gp/seal-phoque/reports-rapports/mgtplan-planges20112015/mgtplanplanges20112015-eng.htm). [Accessed 18/06/14]

DFO (2012) Current Status of Northwest Atlantic Harp Seals, (Pagophilus groenlandicus). DFO Can. Sci. Advis. Sec. Sci. Advis. Rep. 2011/070. 
DFO (2014) Stock Assessment of Canadian grey seals (Halichoerus Grypus). DFO Can. Sci. Advis. Sec. Sci. Advis. Rep. 2014/010.

DFO (2014) Status of Northwest Atlantic harp seals, Pagophilus groenlandicus. DFO Can. Sci. Advis. Sec. Sci. Advis. Rep. 2014/011.

Dodds, K. \& Hemmings, A.D. (2013) Britain and the British Antarctic Terriotory in the wider geopolitics of the Antarctic and Southern Ocean. International Affairs, 89, 1429-1444

Eero, M., MacKenzie, B.R., Köster, F.W. \& Gislason, H. (2010) Multi-decadal responses of a cod (Gadus morhua) population to human-induced trophic changes, fishing, and climate. Ecological Applications, 21, 214-226.

EFSA (2007) Scientific Opinion of the Panel on Animal Health and Welfare on a request from the Commission on the Animal Welfare aspects of the killing and skinning of seals. The EFS A Journal, 610, 1- 122.

Erickson, A.W. \& Hanson, M.B. (1990) Continental estimates and population trends of Antarctic ice seals. Antarctic Ecosystems. Ecological change and conservation (eds K. R. Kerry and G. Hempel), pp. 253-264, Springer-Verlag, Heidelberg, Germany.

Federal Fur Seal Act of 1966 - http://www.animallaw.info/statutes/stus... [Accessed 02/08/14]

Federal Register (2014) The Federal Register: Proposed Rule: Subsistence Taking of Northern Fur Seals on the Pribilof Islands; Summary of Fur Seal Harvests for 2011-2013 and Proposed Annual Harvest Estimates for 2014-2016.

https://www.federalregister.gov/articles/search?conditions[agency_ids] $]=361$ \&order=newest\& page $=23 \&$ quiet $=$ true $[$ Accessed 20/06/14]

Fisheries and Oceans Canada (2014) Seals and Science at Fisheries and Oceans Canada. (http://www.dfo-mpo.gc.ca/fm-gp/seal-phoque/facts-faits/facts-faitsa-eng.htm). [Accessed 18/06/14]

Fine, L. (2012) Booming New England Seal Population Creates a Management Challenge. New England Fisheries, TalkingFish.org www.talkingfish.org/.../booming-new-england-seal-populationcreates-a-...[Accessed 18/06/14]

Fink, S. (2011) A major victory as Russia bans trade in harp seal furs. IFAW post 19/12/2011. http:/ /www.ifaw.org/united-states/news/major-victory-russia-bans-trade-harp-seal-skins [Accessed 24/06/14]

Ford, J.D., Bolton, K.C., Shirley, J., Pearce, T., Tremblay, M. \& Westlake, M. (2012) Research on the Human Dimensions of Climate Change in Nunavut, Nunavik, and Nunatsiavut: A Literature Review and Gap Analysis. ARCTIC, 65, 289-304.

Fowler, C. (1982) Interactions of northern fur seals and commercial fisheries. Transaction of the FortySeventh North American Wildlife Conference (ed K. Sabol), pp. 278-292, Washington, D.C.

Fowler, C.W. (1987) Marine debris and northern fur seals: A case study. Marine Pollution Bulletin, 18, 326335.

Frank, K.T., Petrie, B., Fisher, J.A.D. \& Leggett, W.C. (2011) Transient dynamics of an altered large marine ecosystem. Nature, 477, 86-89.

Fulton, E.A., Smith, A.D.M., Smith, D.C. \& Johnson, P. (2014) An Integrated Approach Is Needed for Ecosystsm Based Fisheries Management: Insights from Ecosystem-Level Management Strategy Evaluation. PLoS ONE, 9, e84242.

Gelatt, T. \& Lowry, L. (IUCN SSC Pinniped Specialist Group) (2008) Callorbinus ursinus. In: IUCN 2014. IUCN Red List of Threatened Species. Version 2014.1. <www.iucnredlist.org>. [Accessed 20/6/ 2014]

Garde, E. (2013) Seals in Greenland: - An important component of culture and economy. The Last Ice Area Project. WWF Denmark. 46pp. http://www.wwf.dk/arktis. Accessed 24/06/14. 
Government of Canada, Marine Mammal Regulations - SQR 9356 (http:/ lawslois.justice.gc.ca/eng/regulations/SOR-93-56/index.html). [Accessed 17/07/14]

Government of Canada, Ministry of Justice, Fisheries Act R.S.C., 1985, c. F-14, Current to June 12, 2014 Last amended on November 25, 2013 http://laws-lois.justice.gc.ca [Accessed 17/07/14]

Government of Greenland (2012a) Management and utilization of seals in Greenland. Government of Greenland, Ministry of Fisheries, Hunting and Agriculture, Revised April 2012. 43pp.

Government of Greenland (2012b) Fact Sheet - Seals - Greenland. [Accessed 24/06/14]

Government of Norway (2013) Sealing. http://www.fisheries.no/ecosystems-andstocks/marine_stocks/mammals/seals/sealing/\#.VJnKv0A9rA [Accessed 18/06/14]

Hammill, M.O. \& Stenson, G.B. (2010) Comment on "Towards a precautionary approach to managing Canada's commercial harp seal hunt” by Leaper et al. ICES Journal of Marine Science: Journal du Conseil, 67, 321-322.

Harding, K.C. and Härkönen, T.J. (1999) Development in the Baltic grey seal (Halichoerus grypus) and ringed seal (Phoca hispida) populations during the 20th century. Ambio 28, 619-627.

Harder, M.T. \& Wenzel, G.W. (2012) Inuit Subsistence, Social Economy and Food Security in Clyde River, Nunavut. Arctic, 65, 305-

Hjermann, D.Ø., Ottersen, G. \& Stenseth, N.C. (2004) Competition among fishermen and fish causes the collapse of Barents Sea capelin. Proceedings of the National Academy of Sciences. 101, 11 679-11 684.

Hjermann, D.Ø., Bogstad, B., Eikeset, A.M., Ottersen, G., Gjøsæter, H. \& Stenseth, N.C. (2007) Food web dynamics affect Northeast Arctic cod recruitment. Proceedings of the Royal Society B: Biological Sciences, 274, 661-669.

Hossain, K. (2013) The EU ban on the import of seal products and the WTO regulations: neglected human rights of the Arctic indigenous peoples? Polar Record, 49, 154-166.

Hovelsrud, G. K., McKenna, M. and Huntington, H. P. (2008) Marine mammal harvests and other interactions with humans. Ecological Applications, 18(2) Supplement, S135-S147.

Hutchings, L., van der Lingen, C.D., Shannon, L.J., Crawford, R.J.M., Verheye, H.M.S., Bartholomae, C.H., van der Plas, A.K., Louw, D., Kreiner, A., Ostrowski, M., Fidel, Q., Barlow, R.G., Lamont, T., Coetzee, J., Shillington, F., Veitch, J., Currie, J.C. \& Monteiro, P.M.S. (2009) The Benguela Current: An ecosystem of four components. Progress in Oceanography, 83, 15-32.

ICES (2015) Report of the Working Group on Harp and Hooded Seals (WGHARP), 26-30 August 2013, PINRO, Murmansk, Russia. ICES CM 2013/ACOM: 20. 59 pp.

IUCN (2007) Guidelines for Applying the Precautionary Principle in Conservation and Natural Resource Management. http:// cmsdata.iucn.org/downloads/ln250507_ppguidelines.pdf [Accessed 23/02/15]

Jackson, J.B.C. (2001) What was natural in the coastal oceans? Proceedings of the National Academy of Sciences, 98, 5411-5418.

Jackson, J.B.C., Kirby, M.X., Berger, W.H., Bjorndal, K.A., Botsford, L.W., Bourque, B.J., Bradbury, R.H., Cooke, R., Erlandson, J., Estes, J.A., Hughes, T.P., Kidwell, S., Lange, C.B., Lenihan, H.S., Pandolfi, J.M., Peterson, C.H., Steneck, R.S., Tegner, M.J. \& Warner, R.R. (2001) Historical overfishing and the recent collapse of coastal Ecosystems. Science, 293, 629-637.

Jessen, A. (2012) The implications for Greenland on the EU policy on whaling and sealing. Slide Presentation at Conference on Marine Mammals, "Hunting and Protecting Marine Mammals - A Clash of Cultures?” June 4-5, Torshavn, Faroese Islands.

Kendrick, A. (2013) Canadian Inuit sustainable use and management of Arctic species. International Journal of Environmental Studies, 70, 414-428. 
Kingdom of Denmark (2011) Denmark, Greenland and the Faroe Islands: Kingdom of Denmark Strategy for the Arctic 2011-2020. Ministry of Foreign Affairs, Copenhagen. 58pp..

http://www.ec.europa.eu/enterprise/policies/raw-materials/.../mss-denmark_en.pdf [Accessed 24/06/14]

Kirkman, S. P. (2010) The Cape Fur Seal: Monitoring and Management in The Benguela Current Ecosystem. PhD Thesis, University of Cape Town, Cape Town, South Africa.

Kirkman, S.P., Yemane, D., Oosthuizen, W.H., Meÿer, M.A., Kotze, P.G.H., Skrypzeck, H., Vaz Velho, F. \& Underhill, L.G. (2013) Spatio-temporal shifts of the dynamic Cape fur seal population in southern Africa, based on aerial censuses (1972-2009). Marine Mammal Science, 29, 497-524.

Königson, S. (2011) Seals and Fisheries - A Study of the Conflict and Some Possible Solutions. PhD dissertation, Gothenburg University, Gothenburg

Königson, S. \& Lunneryd, S. (2012) Development of alternative fishing gear in the Swedish small-scale coastal fisheries. Progress in Marine Conservation in Europe 2012, Proceedings of the Symposium Stralsund, Germany 18-22 June 2012. (eds H. Nordheim, K. Maschner, \& K. Wollny-Goerke) pp. 217-227, Federal Agency for Nature Conservation (BfN), Germany.

Kovacs, K. (no date) Background Document for Development of a Circumpolar Ringed Seal (Phoca bispida) Monitoring Plan. [Accessed 25/06/14]

Kovacs, K. (IUCN SSC Pinniped Specialist Group) (2008) Cystophora cristata. In: IUCN 2014. IUCN Red List of Threatened Species. Version 2014.1. <www.iucnredlist.org>. [Accessed 23/0614]

Kovacs, K.M., Lydersen, C., Overland, J.E. \& Moore, S.E. (2011) Impacts of changing sea-ice conditions on Arctic marine mammals. Marine Biodiversity, 41, 181-194.

Kovacs, K. and Lydersen, C. (2012) Impacts of declining sea ice on marine mammals in the Arctic. Marine Mammals of the Holarctic. Collections of Scientific Papers after the 7 th International Conference. Suzdal, Russia, Sept. 24-28, 2012. Pp. 301-303

Kovacs, K.M., Aguilar, A., Aurioles, D., Burkanov, V., Campagna, C., Gales, N., Gelatt, T., Goldsworthy, S.D., Goodman, S.J., Hofmeyr, G.J.G., Härkönen, T., Lowry, L., Lydersen, C., Schipper, J., Sipilä, T., Southwell, C., Stuart, S., Thompson, D. \& Trillmich, F. (2012) Global threats to pinnipeds. Marine Mammal Science, 28, 414-436.

Krämer, L. (2012) Seal Killing, the Inuit and European Union Law. Review of European Community \& International Environmental Law, 21, 291-296.

Kuhn, C.E., Baker, J.D., Towell, R.G. \& Ream, R.R. (2014) Evidence of localized resource depletion following a natural colonization event by a large marine predator. Journal of Animal Ecology, 83, 1169-1177.

Laist, D.W. (1987) Overview of the biological effects of lost and discarded plastic debris in the marine environment. Marine Pollution Bulletin, 18, 319-326.

Lamers, M., Liggett, D. \& Tin, T. (2014) Strategic Thinking for the Antarctic Environment: The Use of Assessment Tools in Governance. Antarctic Futures. (eds T. Tin, D. Liggett, P-T Maher, \& M. Lamers, pp. 307-327, Springer, Netherlands.

Leaper, R., Lavigne, D.M., Corkeron, P. \& Johnston, D.W. (2010) Towards a precautionary approach to managing Canada's commercial harp seal hunt. ICES Journal of Marine Science: Journal du Conseil, 67, $316-320$.

Lee, O.A., Burkanov, V. \& Neill, W.H. (2014) Population trends of northern fur seals (Callorhinus ursinus) from a metapopulation perspective. Journal of Experimental Marine Biology and Ecology, 451, 25-34.

Lelli, B., Harris, D.E. \& Aboueissa, A-M. (2009) Seal Bounties in Maine and Massachusetts, 1888 to 1962. Northeastern Naturalist, 16, 239-254.

Lewison, R.L., Crowder, L.B., Read, A.J. \& Freeman, S.A. (2004) Understanding impacts of fisheries bycatch on marine megafauna. Trends in Ecology \& Evolution, 19, 598-604. 
Lewison, R.L., Crowder, L.B., Wallace, B.P., Moore, J.E., Cox, T., Zydelis, R., McDonald, S., DiMatteo, A., Dunn, D.C., Kot, C.Y., Bjorkland, R., Kelez, S., Soykan, C., Stewart, K.R., Sims, M., Boustany, A., Read, A.J., Halpin, P., Nichols, W.J. \& Safina, C. (2014) Global patterns of marine mammal, seabird, and sea turtle bycatch reveal taxa-specific and cumulative megafauna hotspots. Proceedings of the National Academy of Sciences, 111, 5271-5276.

Lotze, H.K. \& Milewski, I. (2006) Two centuries of multiple human impacts and succession changes in a North Atlantic food web. Ecological Applications, 14: 1428-1447.

Lydersen, C., Chernook, V.I., Glazov, D.M., Trukhanova, I.S. \& Kovacs, K.M. (2012) Aerial survey of Atlantic walruses (Odobenus rosmarus rosmarus) in the Pechora Sea, August 2011. Polar Biology, 35, 1555-1562.

Lynge, A. (2013) Chair, Inuit Circumpolar Council, ppt presentation - Session III Protection and Conservation of Oceans, Seas and Marine Resources Environmental Conservation [sic] in Polar Regions.

http://www.sustainabledevelopment.un.org/content/documents/1768Final\%20ALrepresentatio n_EGM_April2013x_300413.pdf. [Accessed 24/06/14]

McClelland, G. (2002) The trouble with sealworms (Pseudoterranova decipiens species complex, Nematoda): a review. Parasitology, 124, 183-203.

Maschner, H.D.G., Trites, A.W., Reedy-Maschner, K.L. \& Betts, M. (2014) The decline of Steller sea lions (Eumetopias jubatus) in the North Pacific: insights from indigenous people, ethnohistoric records and archaeological data. Fish and Fisheries, 15, 634-660.

Marine Mammal Commission (2008) Review of Co-management efforts in Alaska. Marine Mammal Commission, Anchorage, Alaska, 72pp.

Marine Mammal Protection Act 1972 (As amended 2007) http://www.nmfs.noaa.gov/pr/laws/mmpa/ [Accessed 02/08/14]

Meek, C.L. (2009) Comparing marine mammal co-management regimes in Alaska: three aspects of institutional performance. PhD Thesis, University of Alaska Fairbanks. 245 pp.

Meek, C.L., Lauren Lovecraft, A., Varjopuro, R., Dowsley, M. \& Dale, A.T. (2011) Adaptive governance and the human dimensions of marine mammal management: implications for policy in a changing North. Marine Policy, 35, 466-476.

Meek, C.L. (2013) Forms of collaboration and social fit in wildlife management: A comparison of policy networks in Alaska. Global Environmental Change, 23, 217-228.

Moore, J.E., Wallace, B.P., Lewison, R.L., Žydelis, R., Cox, T.M. \& Crowder, L.B. (2009) A review of marine mammal, sea turtle and seabird bycatch in USA fisheries and the role of policy in shaping management. Marine Policy, 33, 435-451.

Ministry of Fisheries and Marine Resources (MFMR) Annual Reports, 2005 - 2009, 2010-211.

Morissette, L., Hammill, M.O. \& Savenkoff, C. (2006) The Trophic Role of Marine Mammals in the Northern Gulf of St. Lawrence. Marine Mammal Science, 22, 74-103.

Müller-Wille, L., Kingsley, M. C. S., Nielsen, S. S. (eds.) (2005) Socio-Economic Research on Management Systems of Living Resources: Strategies, Recommendations and Examples. Proceedings of the Workshop on 'Social and economic research related to the management of marine resources in West Greenland' organised by and held at the Greenland Institute of Natural Resources, Nuuk (Greenland), 18-20 November 2003. Inussuk, Artic Research Journal, 1.

NAMMCO Expert Group (2009) Report of the NAMMCO Expert Group meeting on best practices in the hunting and killing of seals. Copenhagen, Denmark. 30 pp. Available from:

http://www.nammco. no/webcronize/images/Nammco/930.pdf [accessed December, 2014].

NMFS (2007) Conservation Plan for the Eastern Pacific Stock of Northern Fur Seal (Callorbinus ursinus). U.S. Department of Commerce National Oceanic and Atmospheric Administration National Marine Fisheries Service Alaska Region, Juneau, Alaska 
Norwegian Embassy, Azerbaijan. Norwegian sealing http://www.norway.az/ARKIV/policy/marine/sealing [Accessed 25/06/14]

Norwegian Ministry of Fisheries and Coastal Affairs (2013) Facts about Fisheries and Aquaculture - 2013. [Accessed 7/07 2014]

http://www.regjeringen.no/upload/FKD/Vedlegg/Rapporter/2013/L-0553E_WEBHele.pdf.

Norwegian-Russian Joint Commission (2005) Report of the working group on seals. Appendix 8. The 34th Session Of The Joint Norwegian - Russian Fisheries Commission, Kaliningrad, Russia, 24 28 October 2005.

Norwegian-Russian Joint Commission (2011) Report of the working group on seals. Appendix 8. The 40th Session of the Joint Norwegian - Russian Fisheries Commission, Kaliningrad, Russia, 10-14 October 2011.

Norwegian-Russian Joint Commission (2012) Report of the working group on seals Appendix 8. The 42nd Session of the Joint Norwegian - Russian Fisheries Commission, Trondheim, Norway, 8-11 October 2012,

Norwegian-Russian Joint Commission (2013) Report of the working group on seals Appendix 8. The 43rd Session of the Joint Norwegian - Russian Fisheries Commission, St. Petersburg, Russia, 811 October 2013.

Nuttal, M. and Callaghan, T. V. (eds) (2000) The arctic environment, people, and policy. Harwood Academic, Amsterdam.

Nuttall, M., Berkes, F., Forbes, B., Kofinas, G., Vlassova, T. and Wenzel, G. (2005) Hunting, Herding, Fishing and Gathering: Indigenous Peoples and Renewable Resource Use in the Arctic. Chapter 12 pages 649-690 In: ACIA, Arctic Climate Impact Assessment, Cambridge University Press, Cambridge. http://www.acia.uaf.edu/pages/scientific.html [Accessed 26/08/14]

Øigård, T.A., Haug, T. \& Nilssen, K.T. (2014a) From pup production to quotas: current status of harp seals in the Greenland Sea. ICES Journal of Marine Science: Journal du Conseil, 71, 537-545.

Øigård, T.A., Haug, T. \& Nilssen, K.T. (2014b) Current status of hooded seals in the Greenland Sea. Victims of climate change and predation? Biological Conservation, 172, 29-36.

Pedersen, S. (2012) The Coastal Sámi of Norway and their rights to traditional marine livelihood. Arctic Review on Law and Politics, 3, 51-80.

Peter, A. (2010) The European parliament shuts down seal-product imports - yet again. Above \& Beyond, May/June: 39-42.

Poppel, B. (2006) Interdependency of subsistence and market economies in the Arctic. In: S. Glomsrød and I. Aslaksen (Eds) The Economy of the North (Oslo: Statistics Norway), pp. 65-80.

Protocol on Environmental Protection to the Antarctic Treaty. http://www.antarctica.ac.uk/about_antarctica/geopolitical/treaty/update_1991.php [Accessed 27/06/14.]

Punt A.E., \& Butterworth, D.S. (1995) The effects of future consumption by the Cape fur seal on catches and catch rates of the Cape hakes. 4. Modelling the biological interaction between Cape fur seals Arctocephalus pusillus pusillus and the Cape hakes Merluccius capensis and M. paradoxus. South African Journal of Marine Science 16, 255-285

Read, A.J., Drinker, P. \& Northridge, S. (2005) Bycatch of marine mammals in U.S. and global fisheries. Conservation Biology, 20, 163-169.

Rick, T. C. \& Erlandson, J. M. (2008) Human impacts on ancient marine ecosystems: a global perspective. University of California Press, Berkeley 
Republic of Namibia (2004) Ministry of Fisheries and Marine Resources, Namibia's Marine Resources Policy: Towards responsible development and management of Namibia's marine resources. 27pp. White Paper available from: http://www.mfmr.gov.na/ [Accessed 4/07/ 2014.

Royal Commission (1986a) Seals and sealing in Canada. Report of the Royal Commission, Vol. 1, Canadian Government Publishing Centre, Ottawa. 73 pp.

Royal Commission (1986b) Seals and sealing in Canada. Report of the Royal Commission, Vol. 2. Canadian Government Publishing Centre, Ottawa. 616 pp.

SCOS (2013) Special Committee on Seals. Main Advice. Scientific Advice on Matters Related to the Management of Seal Populations: 2013. http://www.smru.st-andrews.ac.uk/default.aspx [Accessed 07/08/2014]

Shaughnessy, P.D. \& Butterworth, D.S. (1981) Historical trends in the population size of the Cape fur seal (Arctocephalus pusillus). The Worldwide Furbearer Conference Proceedings (eds J.A. Chapman \& D. Pursle) pp. 1305-1327, RR Donnelley and Sons Co., Virginia.

Scheffer, M. \& Carpenter, S. R. (2003) Catastrophic regime shifts in ecosystems: linking theory to observation. Trends in Ecology and Evolution, 18, 648-656.

Small, R.J., Boveng, P.L., Byrd, G.V. \& Withrow, D.E. (2008) Harbor seal population decline in the Aleutian Archipelago. Marine Mammal Science, 24, 845-863.

Smith B, Caraguel C, Crook A, Daoust P-Y, Dunn JL, Lair S, et al. (2005) Improving humane practice in the Canadian harp seal hunt. A report of the Independent Veterinarians' Working Group on the Canadian harp seal hunt. BL Smith Groupwork; 26 pp. Available from: http:/ / www.ccwhc.ca/ivwg.php

Shaughnessy P.D. \& Butterworth, D.S. (1981) Historical trends in the population size of the Cape fur seal (Arctocephalus pusillus). The Worldwide Furbearer Conference Proceedings. (eds Chapman, J.A. \& D. Pursley), pp.1305-1327, R.R. Donnelley and Sons Co., Virginia

Southwell, C., Paxton, C.G.M., Borchers, D., Boveng, P. \& de la Mare, W. 2008. Taking account of dependent species in management of the Southern Ocean krill fishery: estimating crabeater seal abundance off east Antarctica. Journal of Applied Ecology 45, 622-631

Southwell, C., Bengtson, J., Bester, M., Blix, A.S., Bornemann, H., Boveng, P., Cameron, M., Forcada, J., Laake, J., Nordøy, E., Plö̈z, J., Rogers, T., Southwell, D., Steinhage, D., Stewart, B.S., \& Trathan, P. (2012) A review of data on abundance, trends in abundance, habitat use and diet of ice-breeding seals in the Southern Ocean. CCAMLR Science, 19, 49-74.

Stenson, G.B. (2014) Updated Estimates of Harp Seal Removals in the Northwest Atlantic. DFO Can. Sci. Advis. Sec. Res. Doc. 2014/015. v + 35 p.

Tallis, H., Levin, P.S., Ruckelshaus, M., Lester, S.E., McLeod, K.L., Fluharty, D.L. \& Halpern, B.S. (2010) The many faces of ecosystem-based management: Making the process work today in real places. Marine Policy, 34, 340-348.

Taylor, B., Martinez, M., Gerrodette, T., Barlow, J. \& Hrovat, Y. (2006) Lessons from monitoring trends in abundance of marine mammals. Marine Mammal Science, 23, 157-175

The Scottish Government (2010) Marine (Scotland) Act 2010 - Part 6 'Conservation of seals'. http://www.scotland.gov.uk/Topics/marine/seamanagement/marineact/Seals

Thompson, D. \& Härkönen, T. (IUCN SSC Pinniped Specialist Group) (2008a). Phoca vitulina. In: IUCN 2014. IUCN Red List of Threatened Species. Version 2014.1. <www.iucnredlist.org>. [Accessed 23/07/14]

Thompson, D. \& Härkönen, T. (IUCN SSC Pinniped Specialist Group) (2008b). Halichoerus grypus. In: IUCN 2014. IUCN Red List of Threatened Species. Version 2014.1. <www.iucnredlist.org>. [Accessed 23/07/14] 
Travis, J., Coleman, F.C., Auster, P.J., Cury, P.M., Estes, J.A., Orensanz, J., Peterson, C.H., Power, M.E., Steneck, R.S. \& Wootton, J.T. (2014) Integrating the invisible fabric of nature into fisheries management. Proceedings of the National Academy of Sciences, 111: 581-584

Thurstan, R.H., Brockington, S. \& Roberts, C.M. (2010) The effects of 118 years of industrial fishing on UK bottom trawl fisheries. Nature Communications, $1,15$.

Trukhin, A.M. (2009) Current status of pinnipeds in the Sea of Okhotsk. PICES Scientific Report No. 36, 82-89.

Usher, P.J. (2002) Inuvialuit use of the Beaufort Sea and its resources. Arctic, 55, Supplement 1,18-26.

Usher, P.J., Duhaime, G. \& Searles, E. (2003) The Household as an Economic Unit in Arctic Aboriginal Communities, and its Measurement by Means of a Comprehensive Survey. Social Indicators Research, 61, 175-202.

van der Lingen, C.D., Shannon, L.J., Cury, P., Kreiner, A., Moloney, C.L., Roux, J-P., Vaz-Velho, F. (2006) Resource and ecosystem variability, including regime shifts, in the Benguela Current System. Benguela: Predicting a Large Marine Ecosystem (eds V. Shannon, G. Hempel, P. MalanotteRizzoli, C. L. Moloney, \& J. Woods, J), pp.147-185, Elsevier, Amsterdam,

Walters, J. (2012a) Report on the Complaints by Civil Society Organisations, Non Governmental Organizations, Individuals and Other Groups on the Illegalities Pertaining to the Annual Seal Harvest in Namibia. Report of the Ombudsman of Namibia.

Walters, J. (2012b) Report on the Complaints by Civil Society Organisations, Non Governmental Organizations, Individuals and Other Groups on the Illegalities Pertaining to the Annual Seal Harvest in Namibia - a continuation. Report of the Ombudsman of Namibia.

Waring, G. T., Josephson, E., Maze-Foley, K. and Rosel, P. E., (eds.) (2013) U.S. Atlantic and Gulf of Mexico Marine Mammal Stock Assessments - 2012 Volume 1. http://www.afsc.noaa.gov/Publications/assessments.htm

Waring, G. T., Josephson, E., Maze-Foley, K. and Rosel, P. E., (eds.) (2014) U.S. Atlantic and Gulf of Mexico Marine Mammal Stock Assessments - 2013. http://www.afsc.noaa.gov/Publications/assessments.htm

Waylen, K.A., Hastings, E.J., Banks, E.A., Holstead, K.L., Irvine, R.J. \& Blackstock, K.L. (2014) The Need to Disentangle Key Concepts from Ecosystem-Approach Jargon. Conservation Biology, 28, 1215-1224.

Wenzel, G. (1986). Canadian Inuit in a mixed economy: Thoughts on seals, snowmobiles, and animal rights. Native Studies Review, 2(1), 69-82.

Wenzel, G.W. (2009) Canadian Inuit subsistence and ecological instability - if the climate changes, must the Inuit? Polar Research, 28, 89-99.

Westerberg, H. (2010) Potential solutions to the seals-fisheries conflicts. European Parliament, Directorate for Internal Policies, Available at: http://www.europarl.europa.eu/studies [Accessed 4 July 2014]

Wickens, P. A. (1995) A review of operational interactions between pinnipeds and fisheries. FAO Technical Paper 346. FAO, Rome.

WTO (2014) European Communities - Measures Prohibiting the Importation and Marketing of Seal Products, Ab-2014-1 Ab-2014-2, Reports of the Appellate Body.

Yodzis, P. (1998) Local trophodynamics and the interaction of marine mammals and fisheries in the Benguela ecosystem. Journal of Animal Ecology, 67, 635-758.

Yodzis, P. (2001) Must top predators be culled for the sake of fisheries? Trends in Ecology \&o Evolution, 16, 78-84. 


\subsection{Additional relevant literature read but not cited}

AIHTS (Agreement on International Humane Trapping Standards) (1997) Agreement on international humane trapping standards between the European Community, Canada and the Russian Federation (OJ L 42, 14.2.1998, p. 43).

Allen, R., Jarvis, D., Sayer, S. \& Mills, C. (2012) Entanglement of grey seals Halichoerus grypus at a haul out site in Cornwall, UK. Marine Pollution Bulletin, 64, 2815-2819.

Anonymous (2011) Conservation and Management Plan for the Wadden Sea Seal Population 2012-16 http:/ /www.google.co.zw/url?sa=t\&rct=j\&q=\&esrc=s\&source=web\&cd=2\&ved=0CCMQFjA B\&url $=\mathrm{http} \% 3 \mathrm{~A}$

Anonymous (2012) Report on the Impacts of the European Union Seal Ban. Department of Environment, Iqaluit, Nunavut. [Accessed 10/08/21014]

Arnason, R., Hannesson, R. \& Schrank, W.E. (2000) Costs of fisheries management: the cases of Iceland, Norway and Newfoundland. Marine Policy, 24, 233-243.

Baird, R.W., and Hanson, M.B. (1997) Status of the Northern Fur Seal, Callorbinus ursinus. in Canada. Canadian Field-Naturalist, 111, 263-269.

Baker, C.S., Lukoschek, V., Lavery, S., Dalebout, M.L., Yong-un, M., Endo, T. \& Funahashi, N. (2006) Incomplete reporting of whale, dolphin and porpoise "bycatch" revealed by molecular monitoring of Korean markets. Animal Conservation, 9, 474-482.

Ban, N.C., Maxwell, S.M., Dunn, D.C., Hobday, A. J., Bax, N.J., Ardron, J., Gjerde, K.M., Game, E. T., Devillers, R., Kaplan, D.M., Dunstan, P.K., Halpin, P.N. \& Pressey, R.L. (2014) Better integration of sectoral planning and management approaches for the interlinked ecology of the open oceans. Marine Policy, 49, 127-136.

Bengtson, J.L., Hiruki-Raring, L.M., Simpkins, M.A. \& Boveng, P.L. (2005) Ringed and bearded seal densities in the eastern Chukchi Sea, 1999-2000. Polar Biology, 28, 833-845.

Benot, H.P., Swain, D.P., Bowen, W.D., Breed, G.A., Hammill, M.O. \& Harvey, V. (2011) Evaluating the potential for grey seal predation to explain elevated natural mortality in three fish species in the southern Gulf of St. Lawrence. Marine Ecology Progress Series, 442, 149-167.

Bjørge, A., Desportes, G., Waring, G.T. \& Rosing-Asvid, A. (2010) Introduction: The harbour seal (Phoca vitulina ) - a global perspective. NAMMCO Scientific Publications, 8, 7-11.

Bonner, W.N. (1989) Seals and Man—a changing relationship. Biological Journal of the Linnean Society, 38, 53-60.

Bowen, W.D. \& Lidgard, D. (2013) Marine mammal culling programs: review of effects on predator and prey populations. Mammal Review, 43, 207-220.

Braje, T.J. \& Rick, T. C. (eds.) (2011) Human impacts on seals, sea lions and sea otters: integrating archaeology and ecology in the Northwest Pacific. University of California Press, Berkeley.

Braunsberger, K. \& Buckler, B. (2011) What motivates consumers to participate in boycotts: lessons from the ongoing Canadian seafood boycott. Journal of Business Research, 64, 96-102.

Braunsberger, K. (2014) The impact of animal welfare advertising on opposition to the Canadian seal hunt and willingness to boycott the Canadian seafood industry. Anthrozoos: A Multidisciplinary Journal of The Interactions of People \& Animals, 27, 111-125.

Brown, S.L., Bearhop, S., Harrod, C. \& McDonald, R.A. (2012) A review of spatial and temporal variation in grey and common seal diet in the United Kingdom and Ireland. Journal of the Marine Biological Association of the United Kingdom, 92, 1711-1722.

Bruckmeier, K. \& Höj Larsen, C. (2008) Swedish coastal fisheries-From conflict mitigation to participatory management. Marine Policy, 32, 201-211. 
http://www.ccamlr.org/en/document/publications/schedule-conservation-measures-force-2013/14

http://www.ccamlr.org/en/document/publications/basic-documents

Butterworth D.S., Punt A.E., Oosthuizen W.H., \& Wickens P.A. (1995) The effects of future consumption by the Cape fur seal on catches and catch rates of the Cape hakes. 3. Modeling the dynamics of the Cape fur seal Arctocephalus pusillus pusillus. South African Journal of Marine Science 16: $161-183$.

CCAMLR 2007 Schedule of Conservation Measures in force 2007/08 season http://www.ccamlr.org/pu/e/e_pubs/cm/07-08/all.pdf. 11. CCAMLR Fishery Reports ...

Christiansen, H.C. (1968) The Greenland fur industry. Polar Record, 14, 287-292.

Cooke, J., Leaper, R., Wade, P., Lavigne, D. \& Taylor, B. (2012) Management rules for marine mammal populations: A response to Lonergan. Marine Policy, 36, 389-392.

CONSOLIDATION CODIFICATION Fisheries Act R.S.C., 1985, c. F-14 (http://lawslois.justice.gc.ca/eng/acts/F-14/) [Accessed 17/07/14]

Cronin, M., Jessopp, M., Houle, J. \& Reid, D. (2014) Fishery-seal interactions in Irish waters: Current perspectives and future research priorities. Marine Policy, 44, 120-130.

Cronin, M.A., Gerritsen, H.D. \& Reid, D.G. (2012) Evidence of low spatial overlap between grey seals and a specific whitefish fishery off the west coast of Ireland. Biological Conservation, 150, 136-142.

Daoust, P-Y. and Caraguel, C. (2012) The Canadian harp seal hunt: observations on the effectiveness of procedures to avoid poor animal welfare outcomes. Animal Welfare, 21, 445-455.

De Ville, F. (2011) Explaining the Genesis of a Trade Dispute: the European Union's Seal Trade Ban. Journal of European Integration, 34, 37-53.

Dugmore, A.J., McGovern, T.H., Vésteinsson, O., Arneborg, J., Streeter, R. \& Keller, C. (2012) Cultural adaptation, compounding vulnerabilities and conjunctures in Norse Greenland. Proceedings of the National Academy of Sciences, 109, 3658-3663.

European Commission (no date?) Citizens' Summary, Trade in seal products. [Accessed 18/06/14] http://ec.europa.eu/environment/biodiversity/animal_welfare/seals/pdf/citizen_summary.pdf.

Ferguson, H. (2011) Inuit Food (In)Security in Canada: Assessing the Implications and Effectiveness of Policy. Queen's Policy Review, 2, 54-79.

Forbes, B.C., Stammler, F., Kumpula, T., Meschtyb, N., Pajunen, A. \& Kaarlejärvi, E. (2009) High resilience in the Yamal-Nenets social-ecological system, West Siberian Arctic, Russia. Proceedings of the National Academy of Sciences, 106, 22041-22048.

Ford, J.D. (2009) Vulnerability of Inuit food systems to food insecurity as a consequence of climate change: a case study from Igloolik, Nunavut. Regional Environmental Change, 9, 83-100

Ford, J.D. \& Furgal, C. (2009) Foreword to the special issue: climate change impacts, adaptation and vulnerability in the Arctic. Polar Research, 28, 1-9.

Ford, J.D., Smit, B., Wandel, J., Allurut, M., Shappa, K., Ittusarjuat, H. \& Qrunnut, K. (2008) Climate change in the Arctic: current and future vulnerability in two Inuit communities in Canada. Geographical Journal 174, 45-62.

Ford, J.D., Smit, B. \& Wandel, J. (2006) Vulnerability to climate change in the Arctic: A case study from Arctic Bay, Canada. Global Environmental Change, 16, 145-160.

Galatius, A. (2012) Recovery of the Grey Seal (Halichoerus grypus) Population in the Southern Baltic. Progress in Marine Conservation in Europe 2012, Proceedings of the Symposium Stralsund, Germany 18-22 June 2012, (eds H. von Nordheim, K. Maschner \& K. Wollny-Goerke), pp. 349-350, Bundesamt für Naturschutz (BfN), Bonn, Germany. 370pp. 
Gazit, T., Lidgard, D. \& Sykes, K. (2013) Changing Environments: Tracking the Scientific, Sociopolitical, Legal, and Ethical Currents of the Grey Seal-Cod Debate in Atlantic Canada. Journal of International Wildlife Law and Policy, 16, 266-299.

Glomsrød and Asleksen (2009) The economy of the North 2008. Statistics Norway. [Accessed 26/08/14] https://ssb.no/a/publikasjoner/pdf/sa112_en/sa112_en.pdf

Goldhar, C. \& Ford, J.D. (2010) Climate Change Vulnerability and Food Security in Qeqertarsuaq, Greenland. Community Adaptation and Vulnerability in Arctic Regions (eds G.K. Hovelsrud \& B. Smit), pp. 263-283. Springer, Netherlands.

Gombay, N. (2005) The Commoditization of Country Foods in Nunavik: A Comparative Assessment of Its Development, Applications, and Significance. Arctic, 58, 115-128.

Gullestad, P., Aglen, A., Bjordal, Å., Blom, G., Johansen, S., Krog, J., Misund, O.A. \& Røttingen, I. (2014) Changing attitudes 1970-2012: evolution of the Norwegian management framework to prevent overfishing and to secure long-term sustainability. ICES Journal of Marine Science: Journal du Conseil, 71, 173-182.

Håkon Hoel, A. (ed.) (2009) Best practices in ecosystem-based oceans management in the Arctic. Report Series 129, Norwegian Polar Institute, Polar Environmental Centre, Tromso. 116 pp. [Accessed $10 / 08 / 14]$

Hammill, M.O. \& Stenson, G.B. (2007) Application of the precautionary approach and conservation reference points to management of Atlantic seals. ICES Journal of Marine Science: Journal du Conseil, 64, 702-706.

Hamilton, 1., Lyster, P. \& Otterstad, O. (2000) Social change, ecology and climate in 20th Century Greenland. Climatic Change 47, 193-211.

Harkonen, T., Harding, K.C., Wilson, S., Baimukanov, M., Dmitrieva, L., Svensson, C.J. \& Goodman, S.J. (2012) Collapse of a Marine Mammal Species Driven by Human Impacts. PLoS ONE, 7, e43130.

Haug, T., Hammill, M.O. \& Ólafsdóttir, D. (2007) Introduction: Grey seals in the North Atlantic and the Baltic. NAMMCO Scientific Publications, 6, 7-12.

Herrera, G.E. \& Hoagland, P. (2006) Commercial whaling, tourism, and boycotts: An economic perspective. Marine Policy, 30, 261-269.

Laidler, G.J., Ford, J.D., Gough, W.A., Ikummaq, T., Gagnon, A.S., Kowal, S., Qrunnut, K. \& Irngaut, C. (2009) Travelling and hunting in a changing Arctic: assessing Inuit vulnerability to sea ice change in Igloolik, Nunavut. Climatic Change, 94, 363-397.

Holma, M., Lindroos, M. \& Oinonen, S. (2014) The Economics of Conflicting Interests: Northern Baltic Salmon Fishery Adaption to Gray Seal Abundance. Natural Resource Modeling, 27, 275-299.

Hovelsrud, G.K., Poppel, B., Oort, B. van \& Reist, J.D. (2011) Arctic Societies, Cultures, and Peoples in a Changing Cryosphere. $A M B I O, 40,100-110$.

Howse, R. \& Langille, J. (2012) Permitting Pluralism: The Seal Products Dispute and Why the WTO Should Accept Trade Restrictions Justified by Non-instrumental Moral Values. Yale Journal of International Law, 37, 367.

Huisamen, J., Kirkman, S., van der Lingen, C., Watson, L., Cockcroft, V., Jewell, R. \& Pistorius, P. (2012) Diet of the Cape fur seal Arctocephalus pusillus pusillus at the Robberg Peninsula, Plettenberg Bay, and implications for local fisheries. African Journal of Marine Science, 34, 431-441.

Hunt Jr., G.L., Blanchard, A.L., Boveng, P., Dalpadado, P., Drinkwater, K.F., Eisner, L., Hopcroft, R.R., Kovacs, K.M., Norcross, B.L., Renaud, P., Reigstad, M., Renner, M., Skjoldal, H.R., Whitehouse, A. \& Woodgate, R.A. (2013) The Barents and Chukchi Seas: Comparison of two Arctic shelf ecosystems. Journal of Marine Systems, 109-110, 43-68.

Huntington, H.P., Kruse, S.A. \& Scholz, A.J. (2009) Demographic and environmental conditions are uncoupled in the social-ecological system of the Pribilof Islands. Polar Research, 28, 119-128. 
Hutchings, J.A., Côté, I.M., Dodson, J.J., Fleming, I.A., Jennings, S., Mantua, N.J., Peterman, R.M., Riddell, B.E., Weaver, A.J., and D.L. VanderZwaag. (2012) Sustaining Canadian marine biodiversity: responding to the challenges posed by climate change, fisheries, and aquaculture. Expert panel report prepared for the Royal Society of Canada, Ottawa.

ICES. Accessed 11/08/14 http://www.ices.dk/explore-us/what-we-do/Pages/default.aspx

IFAW (2012) Economics of Canada's seal hunt - 2011 update. http://www.ifaw.org/canada/resourcecentre/economics-canada $\%$ E2\%80\%99s-commercial-seal-hunt [Accessed 3/01/15]

Johansen, H. P. (2007) Sealing in Norway, critical points and interactions. International Conference on Seals and Society Vaasa, Finland 16 - 18 October 2007. Accessed 25/06/14 http://www.congreszon.fi/@Bin/1645159/Halvard+P++Johansen+Presentation+Vaasa.pdf.

Johnston, D.W., Meisenheimer, P. \& Lavigne, D.M. (2000) An evaluation of management objectives for Canada's commercial harp seal hunt, 1996-1998. Conservation Biology, 14, 729-737.

Kingdom of Denmark (2008) Proposal for a Regulation on Trade in Seal Products. [Accessed 18/06/14]

Kirkman, S.P. \& Lavigne, D.M. (2010) Assessing the hunting practices of Namibia's commercial seal hunt. South African Journal of Science, 106, 1-3.

Kirkman, S., Oosthuizen, W., Meÿer, M., Seakamela, S. \& Underhill, L. (2011) Prioritising range-wide scientific monitoring of the Cape fur seal in southern Africa. African Journal of Marine Science, 33, 495-509.

Klenke, R.A., Ring, I., Kranz, A., Jepsen, N., Rauschmayer, F. \& Henle, K. (2013) Human - Wildlife Conflicts in Europe: Fisheries and Fish-Eating Vertebrates as a Model Case. Springer.

Kovacs, K.M. Lavigne, D. M. (1986) Cystophora cristata. Mammalian Species, No. 258, pp. 1-9, 5 figs

Kovacs, K., Lowry, L. \& Härkönen, T. (IUCN SSC Pinniped Specialist Group) 2008. Pusa hispida. In: The IUCN Red List of Threatened Species. Version 2014.1. <www.iucnredlist.org>. [Accessed 07/07/ 2014]

Lavery, T.J., Roudnew, B., Seymour, J., Mitchell, J.G., Smetacek, V. \& Nicol, S. (2014) Whales sustain fisheries: Blue whales stimulate primary production in the Southern Ocean. Marine Mammal Science, 30, 888-904.

Lavigne, D.M. \& Lynn, W.S. (2011) Canada's commercial seal hunt: it's more than a question of humane killing. Journal of Animal Ethics, 1, 1-5.

Lindegren, M., Östman, Ö. \& Gårdmark, A. (2011) Interacting trophic forcing and the population dynamics of herring. Ecology, 92, 1407-1413.

Linnell, J.D.C. (2011) Can we separate the sinners from the scapegoats? Animal Conservation, 14, 602-603.

Linzey, A. (2006) Ethical critique of the Canadian seal hunt and an examination of the case for import controls on seal products. Journal of Animal Law, 2, 87.

Livernois, J. (2010) The economics of ending Canada's commercial harp seal hunt. Marine Policy, 34, 4253.

Lonergan, M. (2011) Potential biological removal and other currently used management rules for marine mammal populations: a comparison. Marine Policy, 35, 584-589.

Lonergan, M. (2012) The targets of management rules for marine mammal populations require justification: a reply to Cooke et al (2012). Marine Policy, 36, 1188-1190.

Loukacheva, N. (2009) Climate change policy in the Arctic: the cases of Greenland and Nunavut. Pages 327-350 In: Koivurova, T., Keskitalo, E.C.H. \& Bankes, N. (eds.) Climate Governance in the Arctic. Springer, Netherlands.

Lovecraft, A.L. \& Meek, C.L. (2011) The human dimensions of marine mammal management in a time of rapid change: comparing policies in Canada, Finland and the United States. Marine Policy, 35, 427429. 
Luan, X. \& Chaisse, J. (2011) Preliminary Comments on the WTO Seals Products Dispute: Traditional Hunting, Public Morals and Technical Barriers to Trade. Colorado Journal of International Environmental Law and Policy, 22, 79.

Ludynia, K., Roux, J.-P., Jones, R., Kemper, J. \& Underhill, L.G. (2010) Surviving off junk: low-energy prey dominates the diet of African penguins Spheniscus demersus at Mercury Island, Namibia, between 1996 and 2009. African Journal of Marine Science, 32, 563-572.

MacKenzie, B.R., Ojaveer, H. \& Eero, M. (2011) Historical ecology provides new insights for ecosystem management: eastern Baltic cod case study. Marine Policy, 35, 266-270.

Magera, A.M., Mills Flemming, J.E., Kaschner, K., Christensen, L.B. \& Lotze, H.K. (2013) Recovery Trends in Marine Mammal Populations. PLOS ONE, 8, e77908.

Marland, A. (2014) If seals were ugly, nobody would give a damn: propaganda, nationalism, and political marketing in the Canadian seal hunt. Journal of Political Marketing, 13, 66-84.

Matejusová, I., Doig, F., Middlemas, S.J., Mackay, S., Douglas, A., Armstrong, J.D., Cunningham, C.O. \& Snow, M. (2008) Using quantitative real-time PCR to detect salmonid prey in scats of grey Halichoerus grypus and harbour Phoca vitulina seals in Scotland - an experimental and field study. Journal of Applied Ecology, 45, 632-640.

Matthiopoulos, J., McConnell, B., Duck, C. \& Fedak, M. (2004) Using satellite telemetry and aerial counts to estimate space use by grey seals around the British Isles. Journal of Applied Ecology, 41, 476-491.

Matthiopoulos, J., Smout, S., Winship, A.J., Thompson, D., Boyd, I.L. \& Harwood, J. (2008) Getting beneath the surface of marine mammal - fisheries competition. Mammal Review, 38, 167-188.

McGivern, B. (2014) The WTO Seal Products Panel - The "Public Morals" defense. Global Trade and Customs Journal, 9, 70-73.

Meis Mason, A., Dana, L-P. and Anderson, R. (2007) 'The Inuit commercial caribou harvest and related agri-food industries in Nunavut', Int. J. Entrepreneurship and Small Business, 4: 785-806.

Merkel, B., Lydersen, C., Yoccoz, N.G. \& Kovacs, K.M. (2013) The World's northernmost harbour seal population - how many are there? PLOS ONE, 8, e67576.

Miller, M.M. \& Rowe, J.E. (2013) Nunavut: a potential new model for economic development. http://search.informit.com.au/documentSummary;dn=356339498356693;res=IELHSS [accessed 10 August 2014]

Molenaar et al (2013) The Law of the Sea and the Polar Regions: Interactions between Global and Regional Regimes (Publications on Ocean Development). Martin Nijhof Publishers

Myers, H., Fast, H. Berkes, M. K. and Berkes, F. (2005) Feeding the family in times of change. Breaking Ice: Renewable Resource and Ocean Management in the Canadian North (ends F. Birkes, R. Huebert, H. Fast, M. Manseau, \& A. Diduck), pp. 23-45 University of Calgary Press, Calgary, Canada.

NAMMCO Annual Report (2013) http://septentrio.uit.no/index.php/NAMMCOSP/index

Natcher, D.C. (2009) Subsistence and the social economy of Canada's aboriginal north. Northern Review, 0, 83-98.

NOAA (2010) Grey Seal www.nefsc.noaa.gov/publications/tm/tm219/184_GRSE.pdf [Accessed $28 / 09 / 14]$

Nunavut wildlife Act -Wildlife Act, SNu 2003, c 26, http://canlii.ca/t/51x1n http://www.canlii.org/en/nu/laws/stat/snu-2003-c-26/latest/snu-2003-c-26.html. [Accessed 10/08/2014]

Nuttall, M. (1990) Animal rights and Greenlandic sealing: a threat to culture survival. Polar Record, 26, $240-242$. 
Nymo, I.H., Tryland, M. \& Godfroid, J. (2011) A review of Brucella infection in marine mammals, with special emphasis on Brucella pinnipedialis in the hooded seal (Cystophora cristata). Veterinary Research, 42, 1-14.

O’Boyle, R. \& Sinclair, M. (2012) Seal-cod interactions on the Eastern Scotian Shelf: Reconsideration of modelling assumptions. Fisheries Research, 115-116, 1-13.

Ó Cadhla, O., Keena, T., Strong, D., Duck, C. and Hiby, L. (2013) Monitoring of the breeding population of grey seals in Ireland, 2009 - 2012. Irish Wildlife Manuals, No. 74. National Parks and Wildlife Service, Department of the Arts, Heritage and the Gaeltacht, Dublin, Ireland. http://edepositireland.ie/handle/2262/69449 [Accessed 6/08/14]

Ottersen, G., Olsen, E., van der Meeren, G.I., Dommasnes, A. \& Loeng, H. (2011) The Norwegian plan for integrated ecosystem-based management of the marine environment in the Norwegian Sea. Marine Policy, 35, 389-398.

Pearce, T., Smit, B., Duerden, F., Ford, J.D., Goose, A. \& Kataoyak, F. (2010) Inuit vulnerability and adaptive capacity to climate change in Ulukhaktok, Northwest Territories, Canada. Polar Record, 46, 157-177.

Perez, M.A. 2003. Compilation of marine mammal incidental take data from the domestic and joint venture groundfish fisheries in the United States EEZ of the North Pacific, 1989-2001. NOAA Technical Memorandum NMFS-AFSC-138, 145 p.

Rauschmayer, F., Wittmer, H. \& Berghöfer, A. (2008) Institutional challenges for resolving conflicts between fisheries and endangered species conservation. Marine Policy, 32, 178-188.

Reeves, R. R. (1998) Distribution, abundance and biology of ringed seals (Phoca hispida): an overview. NAMMCO Scientific Publications, Volume INAMMCO Scientific Publications, 1, 9-45.

Reeves, R.R., Wenzel, G.W. \& Kingsley, M.C. (1998) Catch history of ringed seals ( Phoca hispida ) in Canada. NAMMCO Scientific Publications, 1:100-129.

Roman, J. \& Palumbi, S.R. (2003) Whales Before Whaling in the North Atlantic. Science, 301, 508-510.

Russell, D.J.F., McConnell, B., Thompson, D., Duck, C., Morris, C., Harwood, J. \& Matthiopoulos, J. (2013) Uncovering the links between foraging and breeding regions in a highly mobile mammal. Journal of Applied Ecology, 50, 499-509.

Sava, J. \& Varjopuro, R. (2007) Asymmetries, conflicting interests and the possibilities for cooperation: the case of grey seals in Kvarken. Journal of Environmental Policy \&amp; Planning, 9, 165-184.

Seal Hunter, World Heritage Encyclopedia [Accessed 2/07/14] http://worldheritage.org/articles/Seal_hunter\#cite_note-stat-69

Sellheim, N. (2014) The goals of the EU seal products trade regulation: from effectiveness to consequence. Polar Record, FirstView, 1-16.

Sergeant, D.E. (1976) History and present status of populations of harp and hooded seals. Biological Conservation, 10, 95-118.

Siniff, D.B., Garrott, R.A., Rotella, J.J., Fraser, W.R., \& Ainley, D.G. (2008) Projecting the effects of environmental change on Antarctic seals. Antarctic Science; 20:425-35.

Southwell, C. (IUCN SSC Pinniped Specialist Group) 2008. Lobodon carcinophaga. In: IUCN 2014. IUCN Red List of Threatened Species. Version 2014.1. http:/ /www.iucnredlist.org. [Accessed 23/06/2014]

Sorenson, J. (2011) Ethical fashion and the exploitation of nonhuman animals. Critical Studies in Fashion \& Beauty, 2, 139-164.

Spitz, J., Ridoux, V. \& Brind'Amour, A. (2014) Let's go beyond taxonomy in diet description: testing a trait-based approach to prey-predator relationships. Journal of Animal Ecology, 83, 1149-1157 
Springer, A.M., Estes, J.A., van Vliet, G.B., Williams, T.M., Doak, D.F., Danner, E.M., Forney, K.A. \& Pfister, B. (2003) Sequential megafaunal collapse in the North Pacific Ocean: An ongoing legacy of industrial whaling? Proceedings of the National Academy of Sciences, 100, 12223-12228.

Statistics Greenland (2013) Greenland in Figures 2013. [Accessed 22/07/14]

http:/ $/$ www.stat.gl $/$ dialog $/$ main.asp?lang $=$ en\&version $=201007 \& s c=S A \& s u b t h e m e c o d e=t 12 \& \operatorname{col} c o d=t$

Statistics Greenland (2013) Fisheries catch and agriculture 2010. [Accessed 22/07/14]

Svensson, C.J., Eriksson, A., Harkonen, T. \& Harding, K.C. (2011) Detecting Density Dependence in Recovering Seal Populations. $A M B I O, 40,52-59$.

Sykes, K. (2014) Sealing animal welfare into the GATT exceptions: the international dimension of animal welfare in WTO disputes. World Trade Review, 13, 471-498.

Teilmann, J. \& Kapel, F.O. (1998) Exploitation of ringed seals (Phoca hispida) in Greenland. NAMMCO Scientific Publications, 1, 130-151.

Teilmann, J., Rigét, F. \& Harkonen, T. (2010) Optimizing survey design for Scandinavian harbour seals: population trend as an ecological quality element. ICES Journal of Marine Science: Journal du Conseil, 67, 952-958.

Tester, F.J. (2010) Mad dogs and (mostly) Englishmen: Colonial relations, commodities, and the fate of Inuit sled dogs. Études/Inuit/Studies, 34, 129.

Thompson, P.M., Van Parijs, S. \& Kovacs, K.M. (2001) Local declines in the abundance of harbour seals: implications for the designation and monitoring of protected areas. Journal of Applied Ecology, $38,117-125$.

Tin, T., Lamers, M., Liggett, D., Maher, P.T. \& Hughes, K.A. (2014) Setting the Scene: Human Activities, Environmental Impacts and Governance Arrangements in Antarctica. Antarctic Futures (eds T. Tin, D. Liggett, P.T. Maher \& M. Lamers), pp. 1-24. Springer Netherlands.

Tonder, M. \& Salmi, P. (2004) Institutional changes in fisheries governance: the case of the saimaa ringed seal, Phoca hispida saimensis, conservation. Fisheries Management and Ecology, 11, 283-290.

Torrissen, O., Glover, K.A., Haug, T., Misund, O.A., Skaug, H.J. and Kaiser, M. (2012) Good ethics or political and cultural censoring in science? ICES J. Mar. Sci. 69: 493-497. doi: 10.1093/icesjms/fss016

Trzcinski, M.K., Mohn, R. \& Bowen, W.D. (2006) Continued decline of an Atlantic cod population: how important is gray seal predation? Ecological Applications. 16, 2276-2292.

Varjopuro, R. (2011) Co-existence of seals and fisheries? Adaptation of a coastal fishery for recovery of the Baltic grey seal. Marine Policy, 35, 450-456.

Wegge, N. (2012) Politics between science, law and sentiments: explaining the European Union's ban on trade in seal products. Environmental Politics, 22, 255-273.

Westerberg, H., Lunneryd, S-G., Fjälling, A. \& Wahlberg, M. (2007): Reconciling Fisheries activities with the conservation of seals throughout the development of new fishing gear: a case study from the Baltic fishery-grey seal conflict. American Fisheries Society Symposium, 587-598.

Wilson, S.C., Mo, G. \& Sipila, T. (2009) Legal protection for seals in small populations in European Community and Mediterranean Coastal Waters. Mammalia, 65, 335-348

Wadden Sea seal counts http://www.waddensea-secretariat.org/monitoring-tmap/topics/marinemammals [Accessed 9/08/14] - 2 reports one Harbour seals and one for Grey seals

West Coast Environmental Law (1991) (http://wcel.org/resources/publication/enhancingenvironmental-protection-canadian-constitution-comments-canadian-gov)

WWF-Canada (2012) Seal hunt position statement. [Accessed 17/06/14] 
Young, J.C., Butler, J.R.A., Jordan, A. \& Watt, A.D. (2012) Less government intervention in biodiversity management: risks and opportunities. Biodiversity and Conservation, 21, 1095-1100.

Young, J.C., Jordan, A., Searle, K.R., Butler, A., Simmons, P. \& Watt, A.D. (2013) Framing scale in participatory biodiversity management may contribute to more sustainable solutions. Conservation Letters, 6, 333-340.

Ziryanov, S.V. \& Mishin, V.L. (2007) Grey seals on the Murman coast, Russia: status and present knowledge. NAMMCO Scientific Publications, 6, 13-21. 


\section{ANNEXES}

\subsection{Annnex 1: Terms of reference}

\section{SEAL RANGE STATE POLICY AND MANAGEMENT REVIEW}

\section{Draft Terms of Reference}

To be carried out by SULi in collaboration with Pinniped Specialist Group, for International Fur Federation

\section{Objectives}

The primary objective of the study is to survey range state policy and management responses to growing and/or abundant seal populations. This includes population management for the purposes of sustainable use of seal products, population reduction, and (lethal or non-lethal) management of perceived conflicts with fisheries. The study takes a case study approach, focusing on the following proposed species: Cape fur, Northern fur, hooded, harp, grey, harbor and crabeater seals. The countries covered are Namibia, Canada, European Union countries, Russia, Greenland, Norway, Antarctic, and the USA. There may be scope to amend this list based on preliminary investigations.

The sub-objectives within this broad aim are to:

- survey range states' official policy and management responses to these populations, particularly any measures involving sustainable use and population management;

- survey any policies or regulations of states that have extra-territorial impacts on seal management;

- briefly assess and describe, where relevant, the extent of perceived conflicts between seal populations and fisheries in these range states (and data upon which these conflicts are based);

- review the economic and livelihood value of programs of sustainable use, where these take place and where this can be determined from available data from government and industry sources (including Canada, Greenland, Namibia, Norway, and Russia if possible);

- examine the economic costs of management (lethal and non-lethal) programs not involving use, where this can be determined from available government data;

- developing conclusions regarding the current situation and trends in management of seal populations, including current responses to perceived conflict with fisheries, associated economic benefits and costs, and the coherence of policy measures aimed at territorial vs extra-territorial seal management.

\section{Scope and limitations}

This study is to be based on a limited number of species/country combinations in order to survey a range of approaches to seal management, with a focus on growing/abundant seal stocks. It does not include review or analysis of measures for the protection and recovery of threatened or declining seal populations.

It is recognised that it may be challenging to obtain information about government policies and approaches in some cases, where this information is not made publicly available, and that formal "high level" policies/approaches may in some cases be at variance from activities that gain legal exemptions/authorisations at more local levels, or that are carried out illegally. The study will focus on identifying formal seal management policies. However, it will further seek to "ground truth" this analysis by gaining comment from the Pinniped Specialist Group and reflecting this in an appropriate fashion in the final report.

The study does not seek to address the underlying (and controversial) question of whether growing/abundant seal populations are in fact having ecological or economic impacts on fisheries or 
other socio-economic sectors, or analyse whether seal management measures are reducing of impacts on fisheries.

\section{Methods}

This is a desk-study based on existing published and grey literature, including government reports and data from industry sources, that will be supplemented by interviews with key government, industry or other stakeholders if and where appropriate to gain further information. IFF will work with the project leads to provide information and relevant contacts where appropriate.

\section{Management and technical review}

The contract will be between IFF and IUCN, and on the IUCN side will be managed financially by IUCN Species Programme. Technical management, liaison and oversight will be by SULi, with initial management provided by Rosie Cooney up until mid January 2014, with Shane Mahoney taking on management for the duration.

A small technical team will provide technical oversight, including review of an initial draft of the report. Two members of the Pinniped Specialist Group (Kit Kovacs and Lloyd Lowry) will form part of this team. A consultant (or possibly two with complementary skill sets) will be sought from SULi, PSG, or if no appropriate individuals are available, from elsewhere, to be the lead author on the review.

\section{Timeline}

The project timeline is estimated at up to 7 months from the date of inception (signing of contract), including one month to identify a suitable contractor and technical review panel, 4 months to produce an initial draft, one month for review, and one month for finalization of the report. 


\subsection{Annex 2: CBD Ecosystem Approach Principles}

The following 12 principles are complementary and interlinked.

Principle 1:The objectives of management of land, water and living resources are a matter of societal choices.

Different sectors of society view ecosystems in terms of their own economic, cultural and society needs. Indigenous peoples and other local communities living on the land are important stakeholders and their rights and interests should be recognized. Both cultural and biological diversity are central components of the ecosystem approach, and management should take this into account. Societal choices should be expressed as clearly as possible. Ecosystems should be managed for their intrinsic values and for the tangible or intangible benefits for humans, in a fair and equitable way.

Principle 2: Management should be decentralized to the lowest appropriate level.

Decentralized systems may lead to greater efficiency, effectiveness and equity. Management should involve all stakeholders and balance local interests with the wider public interest. The closer management is to the ecosystem, the greater the responsibility, ownership, accountability, participation, and use of local knowledge.

Principle 3: Ecosystem managers should consider the effects (actual or potential) of their activities on adjacent and other ecosystems.

Management interventions in ecosystems often have unknown or unpredictable effects on other ecosystems; therefore, possible impacts need careful consideration and analysis. This may require new arrangements or ways of organization for institutions involved in decision-making to make, if necessary, appropriate compromises.

Principle 4: Recognizing potential gains from management, there is usually a need to understand and manage the ecosystem in an economic context. Any such ecosystemmanagement programme should:

a. Reduce those market distortions that adversely affect biological diversity;

b. Align incentives to promote biodiversity conservation and sustainable use;

c. Internalize costs and benefits in the given ecosystem to the extent feasible.

The greatest threat to biological diversity lies in its replacement by alternative systems of land use. This often arises through market distortions, which undervalue natural systems and populations and provide perverse incentives and subsidies to favor the conversion of land to less diverse systems.

Often those who benefit from conservation do not pay the costs associated with conservation and, similarly, those who generate environmental costs (e.g. pollution) escape responsibility. Alignment of incentives allows those who control the resource to benefit and ensures that those who generate environmental costs will pay.

Principle 5: Conservation of ecosystem structure and functioning, in order to maintain ecosystem services, should be a priority target of the ecosystem approach.

Ecosystem functioning and resilience depends on a dynamic relationship within species, among species and between species and their abiotic environment, as well as the physical and chemical interactions within the environment. The conservation and, where appropriate, restoration of these interactions and processes is of greater significance for the long-term maintenance of biological diversity than simply protection of species.

Principle 6: Ecosystem must be managed within the limits of their functioning.

In considering the likelihood or ease of attaining the management objectives, attention should be given to the environmental conditions that limit natural productivity, ecosystem structure, functioning and diversity. The limits to ecosystem functioning may be affected to different degrees by temporary, 
unpredictable, and artificially maintained conditions and, accordingly, management should be appropriately cautious.

Principle 7: The ecosystem approach should be undertaken at the appropriate spatial and temporal scales.

The approach should be bounded by spatial and temporal scales that are appropriate to the objectives. Boundaries for management will be defined operationally by users, managers, scientists and indigenous and local peoples. Connectivity between areas should be promoted where necessary. The ecosystem approach is based upon the hierarchical nature of biological diversity characterized by the interaction and integration of genes, species and ecosystems.

Principle 8: Recognizing the varying temporal scales and lag-effects that characterize ecosystem processes, objectives for ecosystem management should be set for the long term.

Ecosystem processes are characterized by varying temporal scales and lag-effects. This inherently conflicts with the tendency of humans to favour short-term gains and immediate benefits over future ones.

Principle 9: Management must recognize the change is inevitable.

Ecosystems change, including species composition and population abundance. Hence, management should adapt to the changes. Apart from their inherent dynamics of change, ecosystems are beset by a complex of uncertainties and potential "surprises" in the human, biological and environmental realms. Traditional disturbance regimes may be important for ecosystem structure and functioning, and may need to be maintained or restored. The ecosystem approach must utilize adaptive management in order to anticipate and cater for such changes and events and should be cautious in making any decision that may foreclose options, but, at the same time, consider mitigating actions to cope with long-term changes such as climate change.

Principle 10: The ecosystem approach should seek the appropriate balance between, and integration of, conservation and use of biological diversity.

Biological diversity is critical both for its intrinsic value and because of the key role it plays in providing the ecosystem and other services upon which we all ultimately depend. There has been a tendency in the past to manage components of biological diversity either as protected or non-protected. There is a need for a shift to more flexible situations, where conservation and use are seen in context and the full range of measures is applied in a continuum from strictly protected to human-made ecosystems

Principle 11: The ecosystem approach should consider all forms of relevant information, including scientific and indigenous and local knowledge, innovations and practices.

Information from all sources is critical to arriving at effective ecosystem management strategies. A much better knowledge of ecosystem functions and the impact of human use is desirable. All relevant information from any concerned area should be shared with all stakeholders and actors, taking into account, inter alia, any decision to be taken under Article 8(j) of the Convention on Biological Diversity. Assumptions behind proposed management decisions should be made explicit and checked against available knowledge and views of stakeholders.

Principle 12: The ecosystem approach should involve all relevant sectors of society and scientific disciplines.

Most problems of biological-diversity management are complex, with many interactions, side-effects and implications, and therefore should involve the necessary expertise and stakeholders at the local, national, regional and international level, as appropriate 


\subsection{Annex 3: Supplementary quotations from Conventions, Acts, and Management Plans}

\section{CITES resolutions}

Resolution Conf. 13.2 (Rev. CoP14) reads as follows:

\section{Sustainable use of biodiversity: Addis Ababa Principles and Guidelines}

WELCOMING the adoption at the seventh meeting of the Conference of the Parties to the Convention on Biological Diversity (CBD COP7), in Decision VII.12, of the Addis Ababa Principles and Guidelines for the Sustainable Use of Biodiversity, a summary of which is contained in Annex 1;

NOTING that these Principles and Guidelines can be utilized in the implementation by CITES Parties of Article IV and other relevant provisions of the Convention;

RECOGNIZING that CBD and its Subsidiary Body on Scientific, Technical and Technological Advice (SBSTTA) will be working on case studies to test these Sustainable Use Principles and Guidelines;

RECOGNIZING further that CBD defines, in its Article 2, the term 'sustainable use' as "the use of components of biological diversity in a way and at a rate that does not lead to the long-term decline of biological diversity, thereby maintaining the potential to meet the needs and aspirations of present and future generations";

NOTING further that the vast majority of CITES Parties are Parties to CBD at the time of the 14th meeting of the Conference of the Parties;

WELCOMING further Target 4.3 of the Strategic Plan: future evaluation of progress of CBD (Decision VII.30, Annex 2, Goal 4), which states that "No species of wild flora or fauna is endangered by international trade", and therefore is fully consistent with the CITES Strategic Plan;

RECALLING Resolution Conf. 10.4 (Rev. CoP14) and the Memorandum of Cooperation between CITES and CBD;

\section{THE CONFERENCE OF THE PARTIES TO THE CONVENTION}

URGES the Parties to:

d. make use of the Principles and Guidelines for the Sustainable Use of Biodiversity, also taking into account scientific, trade and enforcement considerations determined by national circumstances, as well as the recommendations of the Animals and Plants Committees (see Annex 2) when adopting nondetriment-making processes and making CITES non-detriment findings;

e. share experiences on sustainable use at the national level, particularly between CITES Management and Scientific Authorities, and their CBD Focal Points; and1 of 522/02/2012 11:45Resolution Conf. 13.2

f. endeavour to ensure that their CITES Management and Scientific Authorities participate, through their national CBD Focal Points, in the work of CBD and its Subsidiary Body on Scientific, Technical and Technological Advice (SBSTTA) on these Principles and Guidelines; and

URGES the Parties that are also Parties to the CBD, to take effective measures at policy and institutional level to ensure synergy between their implementation of CITES and CBD at the national level.

\section{Conf. 8.3 (Rev. CoP13)* Recognition of the benefits of trade in wildlife}

NOTING that the majority of species of wild fauna and flora that CITES seeks to protect and enhance occur in the developing countries of the world;

RECOGNIZING that the sustainable use of wild fauna and flora, whether consumptive or nonconsumptive, provides an economically competitive land-use option;

BEING AWARE that, unless conservation programmes take into account the needs of local people and provide incentives for sustainable use of wild fauna and flora, conversion to alternative forms of land use may occur;

RECOGNIZING that over-utilization is detrimental to the conservation of wild fauna and flora; RECOGNIZING further that legal trade in a species should not lead to increases in illegal trade anywhere in its range; 
RECOGNIZING also that the returns from legal use may provide funds and incentives to support the management of wild fauna and flora to contain the illegal trade;

ACKNOWLEDGING that the aesthetic, scientific, cultural, recreational and other largely non- consumptive uses of wild fauna and flora are also of enormous importance;

RECOGNIZING that there are many species for which trade would be detrimental to their survival;

\section{THE CONFERENCE OF THE PARTIES TO THE CONVENTION}

RECOGNIZES that commercial trade may be beneficial to the conservation of species and ecosystems or to the development of local people when carried out at levels that are not detrimental to the survival of the species in question; and

RECOGNIZES that implementation of CITES-listing decisions should take into account potential impacts on the livelihoods of the poor.

\section{ICES}

Article I of the convention reads as follows:

It shall be the duty of the International Council for the Exploration of the Sea, hereinafter referred to as the "Council",

a) to promote and encourage research and investigations for the study of the sea particularly those related to the living resources thereof;

b) to draw up programmes required for this purpose and to organise, in agreement with the Contracting Parties, such research and investigation as may appear necessary;

c) to publish or otherwise disseminate the results of research and investigations carried out under its auspices or to encourage the publication thereof.

"ICES is an intergovernmental organization whose main objective is to increase the scientific knowledge of the marine environment and its living resources and to use this knowledge to provide advice to competent authorities. ICES Science and Advice considers both how human activities affect marine ecosystems and how ecosystems affect human activities. In this way, ICES ensures that best available science is accessible for decision-makers to make informed choices on the sustainable use of the marine environment and ecosystems.

To achieve this objective ICES prioritizes, organizes, delivers and disseminates research needed to fill gaps in marine knowledge related to issues of ecological, political, societal, and economic importance at the panAtlantic and global levels.

The main ICES deliverables are scientific publications, and scientific information and management advice requested by member countries and also international organizations and commissions such as the Oslo Paris Commission (OSPAR), the Helsinki Commission - Baltic Marine Environment Protection Commission (HELCOM), the North East Atlantic Fisheries Commission (NEAFC), the North Atlantic Salmon Conservation Organization (NASCO), and the European Commission (EC). Importantly, these products are unbiased, non-political in nature, and based on the best available science." (ICES 2014)

\section{CANADA}

The Fisheries Act (Consolidation Fisheries Act, R.S.C., 1985, c. F-14 Current June 12, 2014)

Section 6 [of the Act] refers to precautionary measures to be considered in respect of regulations made under the Act:

\section{"FACTORS TO BE TAKEN INTO ACCOUNT}

6. Before recommending to the Governor in Council that a regulation be made in respect of section ... [reference to several sections of the act] .... the Minister shall consider the following factors:

(a) the contribution of the relevant fish to the ongoing productivity of commercial, recreational or Aboriginal fisheries;

(b) fisheries management objectives;

(c) whether there are measures and standards to avoid, mitigate or offset serious harm to fish that are 
part of a commercial, recreational or Aboriginal fishery, or that support such a fishery; and

(d) the public interest. R.S., 1985, c. F-14, s. 6; 1991, c. 1, s. 2; 2012, c. 19, s. 135.

6.1 The purpose of section 6 , and of the provisions set out in that section, is to provide for the sustainability and ongoing productivity of commercial, recreational and Aboriginal fisheries.

2012, c. 19, s. 135.”

\section{Section 43 [of the Act]:}

\section{"REGULATIONS}

43. (1) The Governor in Council may make regulations for carrying out the purposes and provisions of this Act and in particular, but without restricting the generality of the foregoing, may make regulations

(a) for the proper management and control of the sea-coast and inland fisheries;

(b) respecting the conservation and protection of fish;

(c) respecting the catching, loading, landing, handling, transporting, possession and disposal of fish;

(d) respecting the operation of fishing vessels;

(e) respecting the use of fishing gear and equipment;

(e.1) respecting the marking, identification and tracking of fishing vessels;

(e.2) respecting the designation of persons as observers, their duties and their carriage on board fishing vessels;

(f) respecting the issue, suspension and cancellation of licences and leases;

(g) respecting the terms and conditions under which a licence and lease may be issued;

(g.1) respecting any records, books of account or other documents to be kept under this Act and the manner and form in which and the period for which they shall be kept;"

The Marine Mammals Regulations (Consolidation Marine Mammal Regulations SOR/93-56 Current to June 12, 2014, Last amended on February 10, 2011) "pursuant to Section 8 and 43, subsection 87(2) of the Fisheries Act" provides for the issuance of licences, seal protection, observation of seal fishing, closed times and seasons, definition of fishing zones, and so on. The prohibitions governing the taking of seals are legally established as follows:

\section{PROHIBITIONS}

27. No person other than a beneficiary ${ }^{28}$ shall sell, trade or barter a whitecoat or blueback.

28. (1) No person shall fish for seals, for personal or commercial use, in any of Sealing Areas 4 to 33 except with

(a) a round club made of hardwood that measures not less than $60 \mathrm{~cm}$ and not more than $1 \mathrm{~m}$ in length and that, for at least half of its length, beginning at one end, measures not less than $5 \mathrm{~cm}$ and not more than $7.6 \mathrm{~cm}$ in diameter;

(b) an instrument known as a hakapik, consisting of a metal ferrule that weighs at least $340 \mathrm{~g}$ with a slightly bent spike not more than $14 \mathrm{~cm}$ in length on one side of the ferrule and a blunt projection not more than $1.3 \mathrm{~cm}$ in length on the opposite side of the ferrule and that is attached to a wooden handle that measures not less than $105 \mathrm{~cm}$ and not more than $153 \mathrm{~cm}$ in length and not less than $3 \mathrm{~cm}$ and not more than 5.1 $\mathrm{cm}$ in diameter;

(c) a rifle and bullets that are not full metal-jacketed that produce a muzzle velocity of not less than 1,800 feet per second and a muzzle energy of not less than 1,100 foot pounds; or

(d) a shotgun of not less than 20 gauge and rifled slugs.

(1.1) No person shall use a club or hakapik to strike a seal older than one year unless the seal has been shot with a firearm.

28/ Where " "beneficiary" means a person who is a beneficiary under

(a) the Agreement approved, given effect and declared valid by the Western Arctic (Inuvialuit) Claims Settlement Act, or

(b) the Agreement approved, given effect and declared valid by the James Bay and Northern Quebec Native Claims Settlement Act; (bénéficiaire)" 
(2) Every person who strikes a seal with a club or hakapik shall strike the seal on the top of the cranium until it has been crushed and shall immediately palpate the cranium to confirm that it has been crushed.

(3) If a firearm is used to fish for a seal, the person who shoots the seal or retrieves it shall palpate the cranium as soon as possible after it is shot to confirm that the cranium has been crushed.

(4) Every person who palpates the cranium of a seal and determines that the cranium is not crushed shall immediately strike the seal with a club or hakapik on the top of its cranium until the cranium has been crushed. SOR/2003-103, s. 6; SOR/2009-66, s. 2.

29. No person shall skin a seal until the cranium has been crushed and at least one minute has elapsed after the two axillary arteries of the seal located beneath its front flippers have been severed to bleed the seal. SOR/2003-103, s. 7; SOR/2009-66, s. 3.

30. No person shall fish for adult harp or hooded seals in whelping or breeding patches.

The 2011-2015 Integrated Fisheries Management Plan for Atlantic Seals (Fisheries and Oceans Canada 2010) provides a comprehensive and explicit statement of policy and management guidelines for the seal fishery in Canadian waters of the North Atlantic. The purpose of the plan is given as follows in the foreword:

"The purpose of this Integrated Fisheries Management Plan (IFMP) is to identify the main objectives and requirements for the Atlantic seal fishery, as well as the management measures that will be used to achieve these objectives. This document also serves to communicate the basic information on the fishery and its management to DFO staff, sealers, legislated co-management boards and other stakeholders. This IFMP provides for more informed stakeholder input into management decisions, and promotes a common understanding of the basic "rules" for the sustainable management of the fisheries resource.

This IFMP is not a legally binding instrument which can form the basis of a legal challenge. The IFMP can be modified at any time and does not fetter the Minister's discretionary powers set out in the Fisheries Act. The Minister can, for reasons of conservation or for any other valid reasons, modify any provision of the IFMP in accordance with the powers granted pursuant to the Fisheries Act."

The IMFP elaborates, inter alia, on the "three step process" for the humane harvesting of seals, outlines the stock assessment process for each species, the adoption of a precautionary approach to the management of seal populations, as well as the use of conservation and target reference points.

The objectives of the management plan are:

\subsection{Objectives long term and short-term (RM)}

3.5.1 Long-term objectives - and integral short-term objective

3.5.1.1 Maintain healthy, abundant seal populations and stable Total Allowable Catches

- maintain the Precautionary Approach (PA)

- maintain N30 as a Critical or Limit Reference Point

o Establish DFO-Industry Working Group to review management options that respect PA, to develop Target Reference Points, and to complete a more thorough evaluation of the management strategy through model simulations

o Discussion and model simulations may lead to some adjustments in the precautionary threshold, currently at N70 (or 70\% of the maximum observed population size)

o N30 is $30 \%$ of the maximum and is a point of fishery closure

- Support market-driven approach to harvest levels which requires professional sealing workforce throughout the Atlantic Region, and management approaches that ensure optimal access (e.g., flexible sealing areas, carry forwards)

\subsubsection{Explore Application of Ecosystem Approach to Seal Management}

- Continue the work of the Grey Seals Working Group to focus sealing, fishing, management, and science expertise on 1) predator-prey interactions and 2) options for expanding the grey seal harvest.

- Broadly disseminate results from Grey Seals work, and promote the development of research agendas and planning objectives for other harvests / fisheries that are mutually supportive.

\subsubsection{Establish and Implement Standards for Animal Welfare}

- Collaborate with sealing industry, provinces, federal agencies, training and certification bodies, 
veterinarians, and the others as appropriate in the elaboration of the existing science basis supporting the three-step process.

- Collaborate with the sealing industry, enforcement officials, training and certification bodies, and others as appropriate in the identification of compliance checkpoints which articulate how the standards are to be met in practice

\subsubsection{Industry fully engaged in the Stewardship of the resource}

- Ensure engagement of seal harvesters in the development and implementation of plan objectives.

- Work with Provinces and Territories, Federal Agencies and Councils, Certification Boards, and Training Providers in support of Professionalization of Seal Harvesters and associated training and certification. This support includes proposal of federal regulatory requirement for mandatory training. Ensure that federal requirements related to animal welfare and marketing of edible seal products are addressed in the training.

- Support sealing industry efforts to:

o implement animal welfare provisions in the Marine Mammal Regulations, including collaboration between industry and veterinary experts.

o adopt protocols for the identification of healthy seals and proper handling of seals intended for the meat and oil market.

o develop innovative products including the use of seal tissues for application in human medicine.

o maintain and/or expand a sealing workforce throughout the Atlantic region to ensure harvesting capacity is available to meet market demand. This support may include lifting of the freeze on new licences.

o Address safety at sea concerns, including a regulatory requirement for vessel registration

o ensure an orderly, well managed harvest, including a requirement for trip limits

\subsubsection{Consideration of social, cultural, and economic factors}

- Socio-Cultural: increase public awareness of the importance of sealing to Inuit and Atlantic Canadians for community cohesion, nutrition, and well-being.

- Economic: promote the identification and development of economic opportunities related to sealing activity.

\subsubsection{A high level of compliance with regulations and licence conditions is achieved}

- Effective monitoring, control and surveillance of the seal harvest in the Gulf of St. Lawrence and in the Newfoundland \& Labrador (Front) areas;

- An orderly, well-managed seal harvest with a high level of compliance with seal fishery management measures, rules and regulations, including the prohibition on the harvest of whitecoat and blueback seals.

- Concerted enforcement efforts to promote strong compliance with regulations and licence conditions related to animal welfare and the three step process.

- The use of proper harvesting techniques and tools will be strictly enforced; Monitoring of, and compliance with, quotas, licences, including hail, log and landings verification.

- Compliance with the regulatory provisions and licence conditions applicable to observation of the seal harvest.

- Compliance monitoring for anticipated new regulatory requirements during the period covered by this plan, namely, mandatory training and registration of sealing vessels.

- A coordinated flow of accurate information to support decision-making, including weekly teleconference between NHQ and regional C\&P coordinators during peak seal harvesting times to evaluate the implementation of the operational plans.

\section{NORWAY}

The emphasis on sustainable use of marine resources is reflected in the country's Marine Resources Act. Although the Act does not mention seals, the relevant sections are as follows: 
Section 1 Purpose

The purpose of this Act is to ensure sustainable and economically profitable management of wild living marine resources and genetic material derived from them, and to promote employment and settlement in coastal communities.

\section{Section 2 Rights to resources}

Wild living marine resources belong to Norwegian society as a whole.

\section{Section 3 Substantive scope}

This Act applies to all harvesting and other utilisation of wild living marine resources and genetic material derived from them. Wild living marine resources means fish, marine mammals that spend part or all of their life cycle in the sea, plants and other marine organisms that live in the sea or on or under the seabed and that are not privately owned

\section{Section 7 Principle for management of wild living marine resources and fundamental considerations}

The Ministry shall evaluate which types of management measures are necessary to ensure sustainable management of wild living marine resources. Importance shall be attached to the following in the management of wild living marine resources and genetic material derived from them:

a) a precautionary approach, in accordance with international agreements and guidelines,

b) an ecosystem approach that takes into account habitats and biodiversity,

c) effective control of harvesting and other forms of utilisation of resources,

d) appropriate allocation of resources, which among other things can help to ensure employment and maintain settlement in coastal communities,

e) optimal utilisation of resources, adapted to marine value creation, markets and industries,

f) ensuring that harvesting methods and the way gear is used take into account the need to reduce possible negative impacts on living marine resources,

g) ensuring that management measures help to maintain the material basis for Sami culture

Sealing regulations from EFSA (2007)

In the commercial bunt of seals in Norway, only registered ocean-going vessels found suitable and equipped for seal hunting can be used. The crew usually consists of 13-15 persons. The master of the vessel is required to attend an annual one-day training and information course held by the Directorate of Fisheries for seal hunters. Members of the crew are required to attend the same course every second year. According to the regulations relating to the hunt, vessels participating in the seal hunt shall keep a catch logbook and carry an inspector (usually a veterinarian) on board during the hunt. Vessels may also be required to carry international observers on board. The role of the international observer is to secure that the catch operations occur according to the rules and regulations relating to the bunt.

It is a requirement that animals which are shot and are lying still, are struck with the sharp end of the hakapik as soon as possible to ensure that they remain unconscious until bled out (the sharp end of the slagkrok may be used on pups instead of a bakapik, but use of the slagkrok on seals $>1$ year old is banned). When bunting on the ice, each marksman is assigned one person whose task is to use the bakapik and to bleed the animals.

Only marksmen who have passed a separate shooting proficiency test may shoot seals during the hunt. A new test must be taken prior to every seal-bunting season. The test shall be taken with the same weapon and the same type of ammunition that will be used during the bunt. Riflemen are required to take a firearm safety course and to register their firearms. They must also pass an annual shooting test with a rifle before they are issued with a licence (Øen, 2006).

Specific regulations (Article 7) include:

- Animals shall be killed in such a way that they do not suffer unnecessarily.

- Adult animals shall be shot. Pups shall be shot or struck with a hakapik or seal club (slagkrok).

- An animal that has been shot shall be struck with a bakapik as soon as possible. A pup may also be struck with a seal club or slagkrok. 
- When a hakapik or seal club (slagkerok) is used, the seal shall be struck on the skull. It shall first be struck with the butt end or blunt projection of the tool, so that the skull is crushed. After that, the animal shall be struck with the spike of the tool, so that it penetrates deep into the brain. If an animal has been shot and is lying still, it is sufficient to use the spike of the tool only.

- Seals shall be bled on the ice immediately after they have been struck with a bakapik or seal club (slagkrok). During bunting of individual seals, seals may be bled on board if they are taken on board immediately and conditions otherwise so indicate.

- Seals shall be bled by making a cut from the underside of the jaw to the end of the breastbone, then cutting the blood vessels to the fore-flippers.

It is probibited to:

a. bunt seal species other than harp seals (in 2007)

b. kill un-weaned pups;

c. $\quad$ bunt adult harp seals in whelping areas;

d. bunt seals that are in the water;

e. shoot seals if conditions are such that they cannot be struck with a bakapik and be bled on the ice;

f. bunt in artificial light;

g. use lines, nets or any form of trap;

b. use shotguns;

i. use a hakapik on adult animals that have not been shot first;

$j$. use a slagkerok on adult animals

k. strike with a hakapik or slagkerok anywhere but on the skull.

A sealing inspector (usually a veterinarian) is required on board each sealing vessel. However, unlike some other bunts, e.g. Canada's commercial seal hunt, no independent (meaning independent of government and industry) observer opinions are available for Norwegian seal bunts.

\section{EUROPEAN UNION}

\subsection{The Habitats Directive:}

The following excerpts from the Directive relate to the conservation of seals within the EU countries.

\section{Article 2}

1. The aim of this Directive shall be to contribute towards ensuring bio-diversity through the conservation of natural habitats and of wild fauna and flora in the European territory of the Member States to which the Treaty applies.

2. Measures taken pursuant to this Directive shall be designed to maintain or restore, at fa vourable conservation status, natural habitats and species of wild fauna and flora of Community interest.

3. Measures taken pursuant to this Directive shall take account of economic, social and cultural requirements and regional and local characteristics.

"Favourable" in respect of a species is defined as follows (Article 1, Definitions - Page 5) :

(i) conservation status of a species means the sum of the influences acting on the species concerned that may affect the long-term distribution and abundance of its populations within the territory referred to in Article 2;

The conservation status will be taken as 'favourable' when:

- population dynamics data on the species concerned indicate that it is maintaining itself on a long-term basis as a viable component of its natural habitats, and

- the natural range of the species is neither being reduced nor is likely to be reduced for the foreseeable future, and

- there is, and will probably continue to be, a sufficiently large habitat to maintain its populations on a long-term basis;

Species of "Community interest' are defined as follows:

(g) species of Community interest means species which, within the territory referred to in Article 2, are:

(i) endangered, except those species whose natural range is marginal in that territory and which are not endangered or vulnerable in the western Palaearctic region; or

(ii) vulnerable, i.e. believed likely to move into the endangered category in the near future if the causal factors continue 
operating; or

(iii) rare, i.e. with small populations that are not at present endangered or vulnerable, but are at risk. The species are located within restricted geographical areas or are thinly scattered over a more extensive range; or

(iv) endemic and requiring particular attention by reason of the specific nature of their habitat and/or the potential impact of their exploitation on their habitat and/or the potential impact of their exploitation on their conservation status.

Such species are listed or may be listed in Annex II and/ or Annex IV or V;

Harbour, grey and ringed seals are listed in Annex II (Page 24)

\section{Protection of species}

\section{Article 14}

1. If, in the light of the surveillance provided for in Article 11, Member States deem it necessary, they shall take measures to ensure that the taking in the wild of specimens of species of wild fauna and flora listed in Annex $V$ as well as their exploitation is compatible with their being maintained at a favourable conservation status.

2. Where such measures are deemed necessary, they shall include continuation of the surveillance provided for in

Article 11. Such measures may also include in particular:

— regulations regarding access to certain property,

- temporary or local probibition of the taking of specimens in the wild and exploitation of certain populations,

- regulation of the periods and/or methods of taking specimens,

- application, when specimens are taken, of hunting and fishing rules which take account of the conservation of such populations,

- establishment of a system of licences for taking specimens or of quotas,

- regulation of the purchase, sale, offering for sale, keeping for sale or transport for sale of specimens,

- breeding in captivity of animal species as well as artificial propagation of plant species, under strictly controlled

conditions, with a view to reducing the taking of specimens of the wild,

— assessment of the effect of the measures adopted. Article 15

\section{Article 15}

In respect of the capture or killing of species of wild fauna listed in Annex $V$ (a) and in cases where, in accordance with Article 16, derogations are applied to the taking, capture or killing of species listed in Annex IV (a), Member States shall probibit the use of all indiscriminate means capable of causing local disappearance of, or serious disturbance to, populations of such species, and in particular:

(a) use of the means of capture and killing listed in Annex VI (a);

(b) any form of capture and killing from the modes of transport referred to in Annex VI (b).

\subsection{The Bern Convention}

\section{Chapter III - Protection of species}

\section{Article 6}

Each Contracting Party shall take appropriate and necessary legislative and administrative measures to ensure the special protection of the wild fauna species specified in Appendix II. The following will in particular be probibited for these species: a. all forms of deliberate capture and keeping and deliberate killing;

$b$. the deliberate damage to or destruction of breeding or resting sites;

c. the deliberate disturbance of wild fauna, particularly during the period of breeding, rearing and hibernation, insofar as disturbance would be significant in relation to the objectives of this Convention;

d. the deliberate destruction or taking of eggs from the wild or keeping these eggs even if empty;

e. the possession of and internal trade in these animals, alive or dead, including stuffed animals and any readily recognisable part or derivative thereof, where this would contribute to the effectiveness of the provisions of this article.

\section{Article 7}

1. Each Contracting Party shall take appropriate and necessary legislative and administrative measures to ensure the protection of the wild fauna species specified in Appendix III.

2. Any exploitation of wild fauna specified in Appendix III shall be regulated in order to keep the populations out of danger, taking into account the requirements of Article 2.

3. Measures to be taken shall include: a. closed seasons and/or other procedures regulating the exploitation; $b$. the temporary or local probibition of exploitation, as appropriate, in order to restore satisfactory population levels; $c$. the regulation as appropriate of sale, keeping for sale, transport for sale or offering for sale of live and dead wild animals.

\section{Article 8}


In respect of the capture or killing of wild fauna species specified in Appendix III and in cases where, in accordance with Article 9, exceptions are applied to species specified in Appendix II, Contracting Parties shall probibit the use of all indiscriminate means of capture and killing and the use of all means capable of causing local disappearance of, or serious disturbance to, populations of a species, and in particular, the means specified in Appendix IV.

\section{Article 9}

1. Each Contracting Party may make exceptions from the provisions of Articles 4, 5, 6, 7 and from the probibition of the use of the means mentioned in Article 8 provided that there is no other satisfactory solution and that the exception will not be detrimental to the survival of the population concerned:

- for the protection of flora and fauna;

- to prevent serious damage to crops, livestock, forests, fisheries, water and other forms of property;

- etc. ....

\subsection{The Helsinki Convention}

RECOMMENDS to the Contracting Parties to the Helsinki Convention:

1: to apply the General Management Principles and Management Units as defined above, and in conformity with these principles develop and implement National Management Plans which will be the main management instruments to ensure that the favourable conservation status of the species is attained or maintained. In particular so that:

- for all populations below the Limit Reference Level (the Safe Biological Level), no allowances for deliberate killing should be issued;

- for populations between the Limit Reference Level (the Safe Biological Level) and the Precautionary Approach Level, licenses for anthropogenic removals can only be issued if in the population a significant positive long-term growth rate can be observed, and if licenses for anthropogenic removals are issued, special care has to be taken so that the positive longterm growth rate is not jeopardized;

- for populations between the Precautionary Approach and the Target Reference Levels, and for population above the Target Reference Level, licenses for anthropogenic removals can be issued provided that the long-term objectives of the General Management Principles are not compromised;

2: to take effective measures for all populations in order to prevent illegal killing, and to reduce incidental bycatches to a minimum level and if possible to a level close to zero;

3: to establish a HELCOM seal expert group with the tasks: · to develop and co-ordinate monitoring programmes and assess the population structure, size and growth, reproduction and breeding distribution, contaminant burden and bealth status, fisheries interactions and bycatches, and evaluate their results;

- to quantify the Limit Reference, Precautionary Approach and Target Reference Levels for populations of the described Management Units;

- to define and quantify similar reference levels with regard to seal distribution and health status;

- to assist in harmonising National Management Plans for those cross-boundary Baltic Sea Seal Management Units described above;

- to draft HELCOM Guidelines for exemptions to the General Management Principles4; · to consider detailed annual Term of Reference for the meetings to be adopted by HELCOM HABITAT;

- to report to HELCOM HABITAT annually;

4: $\quad$ to carry out respective monitoring programmes as indicated above;

5: to collaborate within the HELCOM seal expert group to identify and establish a network of protected areas for important actual and potential seal habitats across the Baltic Sea area (re. the EU Habitat Directive, Annex II), and attempt to harmonize the regulations and monitoring of these conservation areas;

6: to develop and to apply where possible non-lethal mitigation measures for seals to reduce bycatch and damage to fishing gear, as well as to support and coordinate the development of efficient mitigation measures;

\subsection{The OSPAR Convention}

\section{ANNEX V ON THE PROTECTION AND CONSERVATION OF THE ECOSYSTEMS AND BIOLOGICAL DIVERSITY OF THE MARITIME AREA}

\section{ARTICLE 1}

For the purposes of this Annex and of Appendix 3 the definitions of "biological diversity", "ecosystem" and "habitat" are those contained in the Convention on Biological Diversity of 5 June 1992. 


\section{ARTICLE 2}

In fulfilling their obligation under the Convention to take, individually and jointly, the necessary measures to protect the maritime area against the adverse effects of human activities so as to safeguard human health and to conserve marine ecosystems and, when practicable, restore marine areas which have been adversely affected, as well as their obligation under the Convention on Biological Diversity of 5 June 1992 to develop strategies, plans or programmes for the conservation and sustainable use of biological diversity, Contracting Parties shall:

a. take the necessary measures to protect and conserve the ecosystems and the biological diversity of the maritime area, and to restore, where practicable, marine areas which have been adversely affected; and

b. cooperate in adopting programmes and measures for those purposes for the control of the human activities identified by the application of the criteria in Appendix 3.

c. also in doing so, to take account of programmes and measures adopted by Contracting Parties for the protection and conservation of ecosystems within waters under their sovereignty or jurisdiction.

\section{ARTICLE 3}

1. For the purposes of this Annex, it shall inter alia be the duty of the Commission:

to draw up programmes and measures for the control of the human activities identified by the application of the criteria in Appendix 3;

in doing so:

(i) to collect and review information on such activities and their effects on ecosystems and biological diversity;

(ii) to develop means, consistent with international law, for instituting protective, conservation, restorative or precautionary measures related to specific areas or sites or related to particular species or habitats;

(iii) subject to Article 4 of this Annex, to consider aspects of national strategies and guidelines on the sustainable use of components of biological diversity of the maritime area as they affect the various regions and sub-regions of that area;

(iv) subject to Article 4 of this Annex, to aim for the application of an integrated ecosystem approach.

2. whether any particular programme or measure should apply to all, or a specified part, of the maritime area.

In the adoption of such programmes and measures, due consideration shall be given to the question

\section{ARTICLE 4}

1. In accordance with the penultimate recital of the Convention, no programme or measure concerning a question relating to the management of fisheries shall be adopted under this Annex. However where the Commission considers that action is desirable in relation to such a question, it shall draw that question to the attention of the authority or international body competent for that question. Where action within the competence of the Commission is desirable to complement or support action by those authorities or bodies, the Commission shall endeavour to cooperate with them.

2. Where the Commission considers that action under this Annex is desirable in relation to a question concerning maritime transport, it shall draw that question to the attention of the International Maritime Organisation. The Contracting Parties who are members of the International Maritime Organisation shall endeavour to cooperate within that Organisation in order to achieve an appropriate response, including in relevant cases that Organisation's agreement to regional or local action, taking account of any guidelines developed by that Organisation on the designation of special areas, the identification of particularly sensitive areas or other matters. 


\title{
5.6 Scotland - Marine (Scotland) Act 2010
}

\author{
PART 6 \\ CONSERVATION OF SEALS \\ Offence: killing, injuring or taking seals
}

107 Offence: killing, injuring or taking seals

Killing, injuring or taking a live seal (intentionally or recklessly) is an offence.

\section{Exceptions: alleviating suffering}

It is not an offence under section 107 for a person to end a seal's life bumanely (or to injure a seal when attempting to do so) if

(a) it has been seriously disabled (otherwise than by the person's unlawful conduct), (b) it has no reasonable chance of recovering, and (c) ending its life-

(i) is the only satisfactory way to end its suffering, and

(ii) is not detrimental to the maintenance of the population of any species of seal at a favourable conservation status in their natural range (within the meaning of Article 1(e) of the Habitats Directive).

109 Exceptions: licensed activity

It is not an offence under section 107

(a) to kill or take a seal in accordance with a seal licence,

(b) to take a seal in order to, or to injure a seal when attempting to, kill it in accordance with a seal licence,

(c) to kill or injure a seal when attempting to take it in accordance with a seal licence, or

(d) do anything in accordance with a licence granted under regulation 44 of the Conservation (Natural Habitats, \& c.) Regulations.

110 Seal licences

(1) The Scottish Ministers may grant a licence (a "seal licence") authorising the killing or taking of seals-

(a) for scientific, research or educational purposes,

(b) to conserve natural habitats,

(c) to conserve seals or other wild animals (including wild birds) or wild plants,

(d) in connection with the introduction of seals, other wild animals (including wild birds) or wild plants to particular areas,

(e) to protect a zoological or botanical collection,

(f) to protect the health and welfare of farmed fish,

(g) to prevent serious damage to fisheries or fish farms,

(b) to prevent the spread of disease among seals or other animals (including birds) or plants,

(i) to preserve public health or public safety, or

(j) for other imperative reasons of overriding public interest, including those of a social or economic nature and beneficial consequences of primary importance for the environment.

(2) Before granting a seal licence under subsection (1)(g), the Scottish Ministers must have regard to any information they have about-

(a) damage which seals have already done to the fishery or fish farm concerned or to any other fishery or fish farm which is in the vicinity of, or which is of a similar type to, the fishery or fish farm concerned, and

(b) the effectiveness of non-lethal alternative methods of preventing seal damage to the fishery or fish farm concerned or to any other fishery or fish farm which is in the vicinity of, or which is of a similar type to, the fishery or fish farm concerned.

(3) The Scottish Ministers may require an applicant for a seal licence under subsection (1)(g) to provide them with such information about the matters mentioned in paragraphs (a) or (b) of subsection as they reasonably require for the purposes of assisting them to decide whether to grant the seal licence.

111 Methods of killing or taking seals under seal licence

(1) A seal licence must specify the method which the licensee must use to kill or take seals.

(2) The Scottish Ministers must not grant a seal licence authorising a person to kill seals by shooting unless they are satisfied that the person has adequate skills and experience in using firearms.

(3) A seal licence must not authorise a person to do anything which would contravene regulation 41 of the Conservation (Natural Habitats, \& c.) Regulations.

This subsection does not restrict the things for which a licence may be granted under regulation 44 of those Regulations.

112 Seal licence conditions

(1) A seal licence must impose conditions- 
(a) specifying the maximum number of seals which may be killed or taken, and

(b) specifying steps which must be taken in relation to any seal injured when attempting to kill or take it in accordance with the seal licence in order to reduce the risk of it suffering unnecessarily.

(2) A seal licence which authorises the killing of seals by shooting must impose conditions-

(a) specifying the type of firearm which must be used,

(b) specifying the weather conditions in which a person may attempt to shoot a seal,

(c) specifying how close a person must be to a seal before attempting to shoot it,

(d) probibiting a person from attempting to shoot a seal from an unstable platform, and

(e) about the recovery of carcases.

(3) A seal licence may impose other conditions.

(4) Conditions may, for example, specify-

(a) the area in which seals may be killed or taken,

(b) the species of seal which may be killed or taken,

(c) the circumstances in which seals may be killed or taken,

(d) any period during which seals may not be killed or taken, for example, when females of the species of seal for which

the licence has been issued are likely to be in an advanced stage of pregnancy or have dependent pups.

(5) Failure to comply with a condition imposed is an offence.

(6) In any proceedings for such an offence, it is a defence for the person charged to prove that the person took all reasonable precautions and exercised all due diligence to avoid the commission of the offence.

\section{ANTARCTICA}

\subsection{Convention on the Conservation of Antarctic Living Resources (1980)}

The Contracting Parties,

RECOGNISING the importance of safeguarding the environment and protecting the integrity of the ecosystem of the seas surrounding Antarctica;

NOTING the concentration of marine living resources found in Antarctic waters and the increased interest in the possibilities offered by the utilisation of these resources as a source of protein;

CONSCIOUS of the urgency of ensuring the conservation of Antarctic marine living resources;

CONSIDERING that it is essential to increase knowledge of the Antarctic marine ecosystem and its components so as to be able to base decisions on barvesting on sound scientific information;

BELIEVING that the conservation of Antarctic marine living resources calls for international co-operation with due regard for the provisions of the Antarctic Treaty and with the active involvement of all States engaged in research or harvesting activities in Antartic waters;

RECOGNISING the prime responsibilities of the Antarctic Treaty Consultative Parties for the protection and preservation of the Antarctic environment and, in particular, their responsibilities under Article IX, paragraph 1(f) of the Antarctic Treaty in respect of the preservation and conservation of living resources in Antarctica;

RECALLING the action already taken by the Antarctic Treaty Consultative Parties including in particular the Agreed Measures for the Conservation of Antarctic Fauna and Flora, as well as the provisions of the Convention for the Conservation of Antartic Seals;

BEARING in mind the concern regarding the conservation of Antarctic marine living resources expressed by the Consultative Parties at the Ninth Consultative Meeting of the Antarctic Treaty and the importance of the provisions of Recommendation IX2 which led to the establishment of the present Convention;

BELIEVING that it is in the interest of all mankind to preserve the waters surrounding the Antarctic continent for peaceful purposes only and to prevent their becoming the scene or object of international discord;

RECOGNISING, in the light of the foregoing, that it is desirable to establish suitable macbinery for recommending, promoting, deciding upon and co-ordinating the measures and scientific studies needed to ensure the conservation of Antarctic marine living organisms;

$$
\text { HAVE AGREED as follows: }
$$

Article I extends the area of concern to include the Antarctic Convergence Zone. Article II (2) states that "For the purposes of this Convention, the term 'conservation' includes rational use." Article II (3) includes explicit harvesting principles as follows:

3. Any harvesting and associated activities in the area to which this Convention applies shall be conducted in accordance with the provisions of this Convention and with the following principles of conservation: 
(a) prevention of decrease in the size of any harvested population to levels below those which ensure its stable recruitment. For this purpose its size should not be allowed to fall below a level close to that which ensures the greatest net annual increment;

(b) maintenance of the ecological relationships between harvested, dependent and related populations of Antarctic marine living resources and the restoration of depleted populations to the levels defined in sub-paragraph (a) above; and

(c) prevention of changes or minimisation of the risk of changes in the marine ecosystem which are not potentially reversible over two or three decades, taking into account the state of available knowledge of the direct and indirect impact of harvesting, the effect of the introduction of alien species, the effects of associated activities on the marine ecosystem and of the effects of environmental changes, with the aim of making possible the sustained conservation of Antarctic marine living resources.

Article VI makes provision for the precedence of previous conventions as follows:

Nothing in this Convention shall derogate from the rights and obligations of Contracting Parties under the International Convention for the Regulation of Whaling and the Convention for the Conservation of Antarctic Seals.

\subsection{Protocol on Environmental Protection to the Antarctic Treaty (1992)}

The preamble to the protocol reads as follows:

The States Parties to this Protocol to the Antarctic Treaty, hereinafter referred to as the Parties,

Convinced of the need to enhance the protection of the Antarctic environment and dependent and associated ecosystems;

Convinced of the need to strengthen the Antarctic Treaty system so as to ensure that Antarctica shall continue forever to be used exclusively for peaceful purposes and shall not become the scene or object of international discord;

Bearing in mind the special legal and political status of Antarctica and the special responsibility of the Antarctic Treaty Consultative Parties to ensure that all activities in Antarctica are consistent with the purposes and principles of the Antarctic Treaty;

Recalling the designation of Antarctica as a Special Conservation Area and other measures adopted under the Antarctic Treaty system to protect the Antarctic environment and dependent and associated ecosystems;

Acknowledging further the unique opportunities. Antarctica offers for scientific monitoring of and research on processes of global as well as regional importance;

Reaffirming the conservation principles of the Convention on the Conservation of Antarctic Marine Living Resources;

Convinced that the development of a comprehensive regime for the protection of the Antarctic environment and dependent and associated ecosystems is in the interest of mankind as a whole;

Desiring to supplement the Antarctic Treaty to this end;

Have agreed as follows:

Article 2:

\section{$A R T I C L E 2$}

\section{OBJECTIVE AND DESIGNATION}

The Parties commit themselves to the comprehensive protection of the Antarctic environment and dependent and associated ecosystems and hereby designate Antarctica as a natural reserve, devoted to peace and science.

Article 3 of the protocol deals with environmental aspects as follows:

\section{ARTICLE 3}

\section{ENVIRONMENTAL PRINCIPLES}

1. The protection of the Antarctic environment and dependent and associated ecosystems and the intrinsic value of Antarctica, including its wilderness and aesthetic values and its value as an area for the conduct of scientific research, in particular research essential to understanding the global environment, shall be fundamental considerations in the planning and conduct of all activities in the Antarctic Treaty area.

2. To this end:

(a) activities in the Antarctic Treaty area shall be planned and conducted so as to limit adverse impacts on the Antarctic environment and dependent and associated ecosystems;

(b) activities in the Antarctic Treaty area shall be planned and conducted so as to avoid:

(i) adverse effects on climate or weather patterns;

(ii) significant adverse effects on air or water quality;

(iii) significant changes in the atmospheric, terrestrial (including aquatic), glacial or marine environments;

(iv) detrimental changes in the distribution, abundance or productivity of species or populations of species of fauna and flora;

(v) further jeopardy to endangered or threatened species or populations of such species; or

(vi) degradation of, or substantial risk to, areas of biological, scientific, historic, aesthetic or wilderness significance; 
(c) activities in the Antarctic Treaty area shall be planned and conducted on the basis of information sufficient to allow prior assessments of, and informed judgments about, their possible impacts on the Antarctic environment and dependent and associated ecosystems and on the value of Antarctica for the conduct of scientific research; such judgments shall take account of:

(i) the scope of the activity, including its area, duration and intensity;

(ii) the cumulative impacts of the activity, both by itself and in combination with other activities in the Antarctic Treaty area;

(iii) whether the activity will detrimentally affect any other activity in the Antarctic Treaty area;

(iv) whether technology and procedures are available to provide for environmentally safe operations;

(v) whether there exists the capacity to monitor key environmental parameters and ecosystem components so as to identify and provide early warning of any adverse effects of the activity and to provide for such modification of operating procedures as may be necessary in the light of the results of monitoring or increased knowledge of the Antarctic environment and dependent and associated ecosystems; and

(vi) whether there exists the capacity to respond promptly and effectively to accidents, particularly those with potential environmental effects;

(d) regular and effective monitoring shall take place to allow assessment of the impacts of ongoing activities, including the verification of predicted impacts;

(e) regular and effective monitoring shall take place to facilitate early detection of the possible unforeseen effects of activities carried on both within and outside the Antarctic Treaty area on the Antarctic environment and dependent and associated ecosystems. 



\section{IUCN}

\section{INTERNATIONAL UNION}

FOR CONSERVATION OF NATURE

WORLD HEADQUARTERS

Rue Mauverney 28

1196 Gland, Switzerland

Tel +41 229990000

Fax +4122 9990002

www.iucn.org

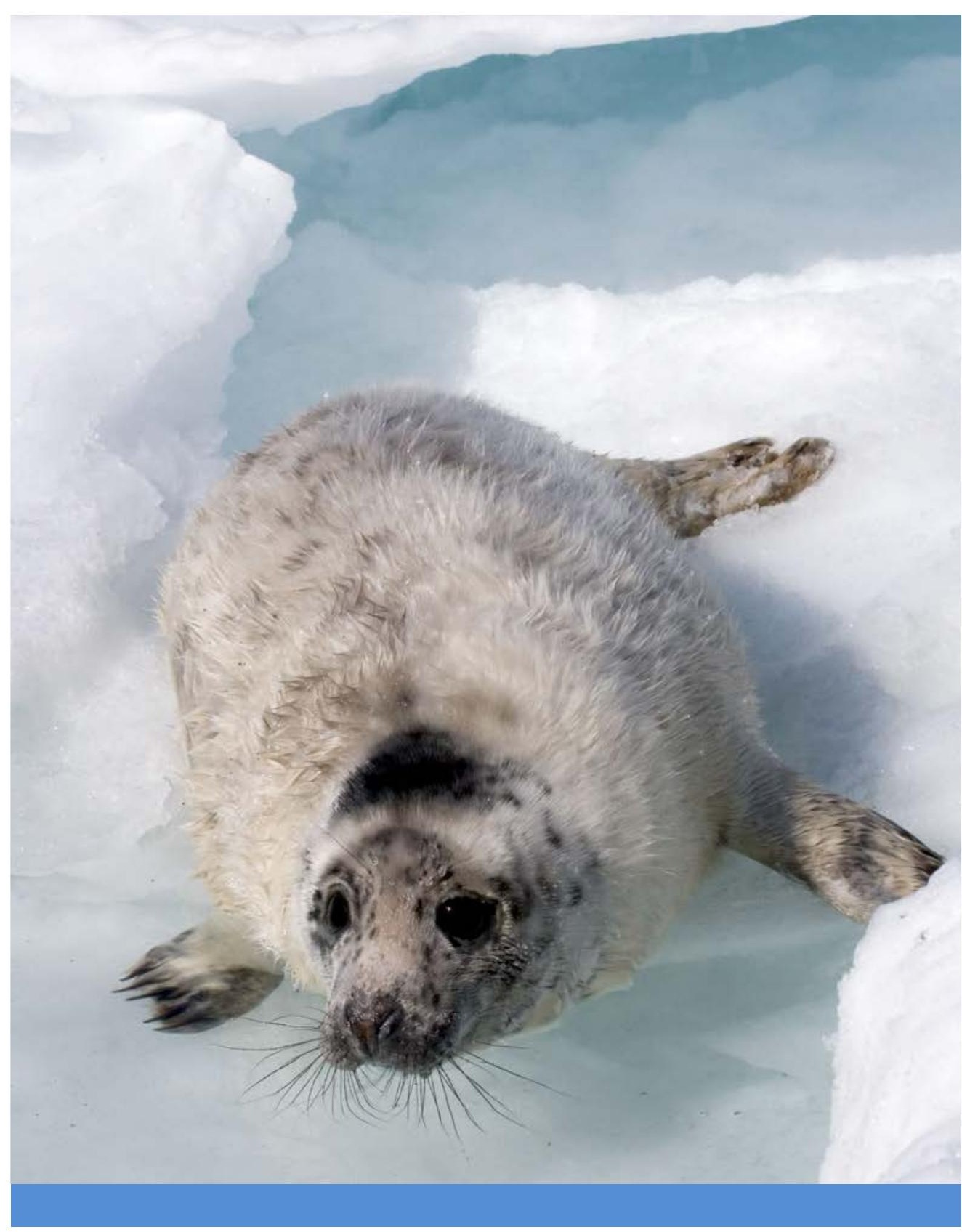

